André Busse Gomes

\title{
AVALIAÇÃO EXPERIMENTAL DE CONDIÇÕES DE CONFORTO TÉRMICO EM AUTOMÓVEIS DE PASSEIO UTILIZANDO MANEQUIM
}

Trabalho de conclusão de curso apresentado à Escola Politécnica da Universidade de São Paulo para obtenção do título de Mestre em Engenharia Automotiva (Mestrado Profissionalizante)

São Paulo 
André Busse Gomes

\section{AVALIAÇÃO EXPERIMENTAL DE CONDIÇÕES DE CONFORTO TÉRMICO EM AUTOMÓVEIS DE PASSEIO UTILIZANDO MANEQUIM}

Trabalho de conclusão de curso apresentado à Escola Politécnica da Universidade de São Paulo para obtenção do título de Mestre em Engenharia

Área de Concentração:

Engenharia Automotiva

(Mestrado Profissionalizante)

Orientador:

Arlindo Tribess

São Paulo

2005 
Este exemplar foi revisado e alterado em relação à versão original, sob responsabilidade única do autor e com a anuência de seu orientador.

São Paulo, 19 de Setembro de 2005

André Busse Gomes

Arlindo Tribess

Autor

Orientador

Gomes, André Busse.

Avaliação Experimental de Condições de Conforto Térmico em Automóveis de Passeio utilizando Manequim. André Busse Gomes. São Paulo, 2005.

$54 \mathrm{p}$.

Trabalho de concluão de curso (Mestrado Profissionalizante em Engenharia Automotiva) - Escola Politécnica da Universidade de São Paulo.

1. Engenharia automotiva 2. Climatização veicular 3. Conforto térmico 4. Manequim 5. Temperatura equivalente 6 . Tecnologia I. Universidade de São Paulo. Escola Politécnica. II. t 
Aos meus pais Antônio e Tânia, pelo apoio e dedicação à minha formação acadêmica.

À Maria Eduarda, pela importante participação e estímulo para a conclusão deste trabalho. 


\section{AGRADECIMENTOS}

Ao meu orientador Prof. Dr. Arlindo Tribess, pela motivação, confiança, paciência inesgotável e cooperação incansável na realização deste trabalho.

Ao colega do Mestrado em Engenharia Mecânica da EPUSP, Victor Barbosa Felix, pela imensa ajuda prestada durante os ensaios em laboratório e em campo.

À graduanda em Engenharia Mecânica pela EPUSP, Cláudia Denise Okuyama, pela fundamental ajuda prestada durante as calibrações do manequim.

Aos professores da Escola Politécnica da USP e colegas, pelos momentos de convivência e pela troca de conhecimentos, que tanto enriqueceram minha formação pessoal e acadêmica.

À Mônica e à Rosangêla da Secretaria do Mestrado Profissional em Engenharia Automotiva da EPUSP, pela dedicação e atenção prestadas durante a realização do Curso. A todos que, direta ou indiretamente, colaboraram na execução deste trabalho.

A todos vocês, muito obrigado! 


\section{SUMÁRIO}

\section{LISTA DE FIGURAS}

LISTAS DE TABELAS

LISTA DE ABREVIATURAS E SIGLAS

RESUMO

ABSTRACT

1. INTRODUÇÃO 1

1.1 Objeto de estudo e objetivo do trabalho 3

1.2 Organização do trabalho 3

2. CONFORTO TÉRMICO 4

$2.1 \mathrm{O}$ sistema termorregulador 4

2.2 Conforto térmico e segurança veicular $\quad 5$

$\begin{array}{ll}2.3 \text { Balanço térmico do corpo humano } & 6\end{array}$

2.4 Equação de conforto de Fanger $\quad 7$

$\begin{array}{ll}2.5 \text { Avaliação de ambientes térmicos } & 10\end{array}$

$\begin{array}{ll}\text { 2.5.1 Voto médio estimado (PMV) } & 11\end{array}$

$\begin{array}{ll}\text { 2.5.2 Percentagem de pessoas insatisfeitas (PPD) } & 13\end{array}$

$\begin{array}{ll}\text { 2.5.3 Desconforto térmico local } & 14\end{array}$

3. AVALIAÇÃO DE CONFORTO TÉRMICO EM VEÍCULOS AUTOMOTIVOS

3.1 Avaliação de conforto térmico em ambientes não homogêneos 15

3.2 Avaliação de conforto térmico em automóveis 16

3.2.1 Avaliação de conforto térmico realizado pelas empresas montadoras $\quad 16$

3.2.2 Avaliação de conforto térmico pela temperatura da pele 18

3.2.3 Avaliação de conforto térmico em regime transitório 19 


\section{UTILIZANDO MANEQUINS}

$\begin{array}{ll}\text { 4.1 Manequins térmicos } & 21\end{array}$

4.2 Manequins com sensores aquecidos $\quad 24$

4.2.1 Determinação de temperaturas equivalentes utilizando manequim 24

4.2.2 Procedimentos de calibração do manequim 25

5. PROCEDIMENTO DE ENSAIO UTILIZANDO MANEQUIM 28

5.1 Descrição do manequim utilizado nos ensaios 28

$\begin{array}{ll}5.2 \text { Calibração do manequim } & 30\end{array}$

5.3 Procedimento de ensaio nas avaliações nos automóveis 33

5.3.1 Ensaios em condição de verão 36

$\begin{array}{ll}\text { 5.3.2 Ensaios em condição de inverno } & 37\end{array}$

6. RESULTADOS DOS ENSAIOS E ANÁLISE DOS RESULTADOS 38

6.1 Condições de ensaio 38

6.2 Resultados dos ensaios para condições de verão 39

6.3 Resultados dos ensaios para condições de inverno 43

6.4 Análise das condições de conforto térmico 46

6.4.1 Análise das condições de conforto térmico para condições de verão $\quad 47$

6.4.2 Análise das condições de conforto térmico para condições de inverno $\quad 48$

7. CONCLUSÕES

8. REFERÊNCIAS BIBLIOGRÁFICAS 


\section{LISTA DE FIGURAS}

Figura 2.1 Modelo cilindrico da interação térmica: corpo humano - meio 6 envolvente

Figura 2.2 Diagrama psicrométrico com a indicação da zona de conforto em 11 ambientes climatizados segundo a norma ASHRAE 55

$\begin{array}{lll}\text { Figura 2.3 Relaçãoentre PMV e PPD } & 13\end{array}$

$\begin{array}{lll}\text { Figura 3.1 Representação esquemática do problema analisado } & 17\end{array}$

$\begin{array}{lll}\text { Figura 3.2 Índices EHT para } 16 \text { segmentos do corpo } & 18\end{array}$

$\begin{array}{lll}\text { Figura 3.3 Stickman e instrumentação utilizada } & 20\end{array}$

Figura 4.1 Manequim térmico instalado em ambiente simulando uma cabine 21 de automóvel

$\begin{array}{lll}\text { Figura 4.2 Manequim com } 16 \text { segmentos } & 26\end{array}$

Figura 4.3 Diagrama para avaliação de teq em função da sensação térmica: 27 condição de verão, resfriamento

Figura 4.4 Diagrama para avaliação de teq em função da sensação térmica: 27 condição de inverno, aquecimento

Figura 5.1 Manequim com sensores aquecidos utilizado nos ensaios 28

Figura 5.2 Módulo B de controle de potência e conexão de sensores para 29 levantamento de dados ambientais

Figura 5.3 Módula A de aquisição de sinais 29

$\begin{array}{lll}\text { Figura 5.4 Software de aquisição do sistema SimTer } & 30\end{array}$

Figura 5.5 Posicionamento do manequim na câmara para calibração 31

Figura 5.6 Manequim posicionado para ensaio com roupa 0,6 clo 34

Figura 5.7 Manequim posicionado para ensaio com roupa 1,0 clo 34

Figura 5.8 Posição do anemômetro e termômetro na altura da cabeça 35 
Figura 5.9 Posição do anemômetro e termômetro na altura do tórax

Figura 5.10 Posição do anemômetro e termômetro na altura dos pés 36

Figura 5.11 Posição do anemômetro e termômetro na altura do painel 36

Figura 6.1 Gráfico das temperaturas do ar no interior do veículo: condições 39 de verão veículo $\mathrm{A}$

Figura 6.2 Gráfico das temperaturas superficiais do manequim: condições de 40 verão veículo A

Figura 6.3 Gráfico das temperaturas do ar no interior do veículo: condições 41 de verão veículo $\mathrm{B}$

Figura 6.4 Gráfico das temperaturas superficiais do manequim: condições de 41 verão veículo $B$

Figura 6.5 Gráfico das temperaturas do ar no interior do veículo: condições 42 de verão veículo $\mathrm{C}$

Figura 6.6 Gráfico das temperaturas superficiais do manequim: condições de 42 verão veículo $\mathrm{C}$

Figura 6.7 Gráfico das temperaturas do ar no interior do veículo: condições 43 de inverno veículo A

Figura 6.8 Gráfico das temperaturas superficiais do manequim: condições de 43 inverno veículo $\mathrm{A}$

Figura 6.9 Gráfico das temperaturas do ar no interior do veículo: condições 44 de inverno veículo B

Figura 6.10 Gráfico das temperaturas superficiais do manequim: condições de 45 inverno veículo B

Figura 6.11 Gráfico das temperaturas do ar no interior do veículo: condições 45 de inverno veículo $\mathrm{C}$

Figura 6.12 Gráfico das temperaturas superficiais do manequim: condições de 46 inverno veículo $\mathrm{C}$ 
Figura 6.13 Diagrama de zonas de sensação térmica da norma ISO 14505-2

(2004) com os resultados de temperatura equivalente obtidos para condições de verão

Figura 6.14 Diagrama de zonas de sensação térmica da norma ISO 14505-2 (2004) com os resultados de temperatura equivalente obtidos para condições de inverno 


\section{LISTA DE TABELAS}

Tabela 2.1 Metabolismos para diferentes atividades 9

$\begin{array}{lll}\text { Tabela 2.2 Escala de sensação térmica da ASHRAE } & 10\end{array}$

$\begin{array}{lll}\text { Tabela 2.3 Determinação do voto médio estimado - PMV } & 12\end{array}$

Tabela 4.1 Escala de sensação térmica da norma ISO 14505-2. 27

Tabela 5.1 Características dos instrumentos de medição do sistema SimTer 30

Tabela 5.2 Valores dos coeficientes de troca de calor para cada parte do 32 corpo com vestimenta de 0,6 clo (condição de verão)

Tabela 5.3 Valores dos coeficientes de troca de calor para cada parte do 32 corpo com vestimenta de 1,0 clo (condição de inverno) 


\section{LISTA DE SÍMBOLOS}

\begin{tabular}{ll} 
C & Calor Perdido pela Pele por Convecção \\
CR & Calor Convectivo Perdido pela Respiração \\
CFD & Computacional Fluid Dynamics \\
Edif & Calor Perdido pela Pele por Difusão de Vapor D’água \\
Ees & Calor Perdido por Evaporação de Suor \\
ER & Calor Evaporativo Perdido pela Respiração \\
EHT & Equivalent Homogeneous Temperature \\
ELT & Equivalent Living-room Temperature \\
h & Coeficiente de troca de calor combinado, convecção e radiação \\
hcal & Coeficiente de troca de calor calibrado \\
hc & Coeficiente de Transferência de Calor por Condução \\
R & Temperatura do Ar \\
Qpespirção & Calor Total Perdido pela Respiração \\
Pr & Coeficiente de Transferência de Calor por Radiação \\
IR & Resistência Térmica da Roupa \\
M & Metabolismo \\
Pvar & Pressão Parcial do Vapor D'água no Ambiente \\
PD & Percentage os Dissatisfied \\
\hline
\end{tabular}


To

$\mathrm{Tp}$

$\bar{t}_{r}$

ts

$\mathrm{U}$

Var

$\omega$

W

$\Phi$
Temperatura Operativa

Temperatura de Pele

Temperatura Radiante Média

Temperatura de Superfície do Manequim

Taxa de Variação de energia Interna

Velocidade do Ar

Umidade Absoluta

Trabalho Externo

Umidade Relativa do Ar 


\section{RESUMO}

Atualmente as pessoas passam grande parte do tempo dentro de veículos automotivos seja por razões profissionais ou lazer. Este fato tem contribuído para aumentar o interesse das montadoras de veículos na avaliação de condições de conforto de passageiros em veículos automotivos. Os critérios do consumidor, na escolha e compra de um automóvel, têm mudado e agora não envolvem somente aspectos relacionados ao custo e desempenho do veículo, mas também a aspectos de segurança e conforto.

O ambiente térmico no interior de um automóvel é bastante complexo e não homogêneo. A forma mais adequada para se avaliar simultaneamente os efeitos da temperatura do ar local, trocas de calor por radiação do corpo, velocidades do ar e a radiação solar em um veículo é por meio do uso de manequins.

No presente trabalho foi realizado estudo da utilização de manequins na avaliação de condições de conforto térmico em veículos automotivos e a realização de ensaios em automóveis de passeio. Os ensaios foram realizados em três automóveis (veículo A, veículo $\mathrm{B}$ e veículo $\mathrm{C}$ ), modelos standard, com sistema de climatização para avaliação de condições de conforto térmico para condições de verão (resfriamento) e de inverno (aquecimento).

$\mathrm{Na}$ avaliação das condições de conforto térmico foram utilizadas temperaturas equivalentes, cujo procedimento de determinação utilizando manequins foi baseado na norma ISO 14505-2.

Nos ensaios realizados para as condições de verão (resfriamento), pode-se verificar que em nenhum veículo foram observadas condições de conforto térmico para os vários segmentos do manequim quando os veículos estavam ao sol. Já quando o veículo estava sob a sombra, todos os veículos atingiram facilmente uma condição de conforto (com uma leve sensação de frio em alguns segmentos do manequim).

Nos ensaios para condições de inverno (aquecimento) verificou-se que, na ausência da radiação solar e com temperaturas externas mais baixas, os sistemas de climatização conseguiram proporcionar melhores condições térmicas no interior dos veículos, apresentando condições de conforto térmico em quase todas as situações.

$\mathrm{O}$ automóvel B foi o que apresentou as melhores condições de conforto térmico tanto nos ensaios para condições de verão (resfriamento) quanto de inverno (aquecimento); o que é um bom indicativo de um melhor controle e distribuição de ar naquele veículo. 


\begin{abstract}
Nowadays people pass great part of the time inside automotive vehicles due to professional reasons or leisure. This fact has been contributing to increase the OEMs interest in the evaluation of comfort conditions of passengers in automotive vehicles. The consumer's criteria, in the choice and acquisition of an automobile, have been changing and now it does not only involve aspects related to the cost and performance of the vehicle, but also involves aspects of safety and comfort.

The thermal environment inside an automobile is very complex and no homogeneous. The most appropriate form to evaluate simultaneously the effects of the local air temperature, radiation heat changes of the body, air velocities and the solar radiation in a vehicle are by means of the use of mannequins.

In the present work a study of the use of mannequins in the evaluation of thermal comfort conditions in automotive vehicles was done and tests in automobiles were accomplished. The tests were accomplished in three automobiles (vehicle A, vehicle B and vehicle C), standard models, with climatization system for the evaluation of thermal comfort conditions for summer conditions (cooling) and for winter conditions (heating). In the evaluation of thermal comfort conditions equivalent temperatures were used, whose determination procedure using mannequins was based on the norm ISO 14505-2.

In the tests accomplished for summer conditions (cooling), it could be verified that in any vehicle conditions of thermal comfort were observed for the segments of the mannequin when the vehicles were in the sun. Already when the vehicle was under the shadow, all the vehicles reached a comfort condition easily (with a light sensation of cold in some segments of the mannequin).

In the tests for winter conditions (heating) it was verified that, in the absence of the solar radiation and with lower external temperatures, the climatization systems got to provide better thermal conditions inside the vehicles, presenting conditions of thermal comfort in almost all the situations.

The automobile B was what presented the best conditions of thermal comfort so much in the tests for summer conditions (cooling) as for winter conditions (heating); what is a good indicative of a better climatization control and air distribution in that vehicle.
\end{abstract}




\section{CAPÍTULO 1}

\section{INTRODUÇÃO}

Atualmente as pessoas passam grande parte do tempo dentro de veículos automotivos seja por razões profissionais ou lazer. Este fato tem contribuído em muito para aumentar o interesse na avaliação de condições de conforto de passageiros em veículos automotivos. Os critérios do consumidor, na escolha e compra do veículo, têm mudado e agora não envolvem somente aspectos relacionados ao custo e desempenho do veículo, mas também a aspectos de segurança e conforto.

Existem também fatores de marketing do ponto de vista das fabricantes de automóveis (montadoras) no aumento do interesse em melhorar as condições de conforto dos passageiros em veículos. E o conforto interno dos veículos passa a ser um fator cada vez mais importante dentro de um mercado muito competitivo e com modelos muito parecidos em termos de construção e tecnologia, onde detalhes começam a ter um peso grande na decisão de compra dos clientes (Gameiro da Silva, 2002).

Acrescente-se que as condições ambientais, principalmente nos grandes centros urbanos, repletos de poluição sonora, poluição do ar e aspectos de segurança, levam as pessoas a cada vez mais desejarem um ambiente confortável dentro de seus veículos quando estão a conduzi-los. Um veículo com um ambiente interno confortável melhora a segurança dos ocupantes do veículo e reduz a fadiga decorrente de se passar várias horas dentro do veículo.

O ambiente térmico no interior de um veículo automotivo, principalmente em um automóvel, é bastante complexo e não homogêneo. Em um automóvel ocorrem elevados gradientes de temperatura, velocidade do ar e temperatura radiante em condições altamente transientes. Além disso, há uma grande influência da radiação solar através da área envidraçada do veículo e do isolamento térmico causado pelos bancos. (Hosni et al., 2003a).

Dentro deste ambiente térmico complexo estará uma pessoa executando um certo nível de atividade física e vestindo roupas que possuem propriedades de isolamento térmico. Para se obter conforto térmico nestas condições há a necessidade de se ajustar estes fatores dentro de padrões pré-determinados. Para se poder ajustar e controlar estes 
fatores há, normalmente, a necessidade de se adotar sistemas de climatização (HVAC Heating, Ventilating and Ar Conditioning).

O objetivo do sistema HVAC de um veículo automotivo é criar condições de conforto térmico para os ocupantes, independentemente das condições climáticas exteriores e de manter as condições de conforto térmico durante todo o período de utilização do sistema.

A melhor e mais confiável maneira de se avaliar o sistema HVAC de um veículo é utilizar a resposta subjetiva de grupos de seres humanos submetidos às condições térmicas no interior deste veículo. (Nilsson, 2004). Mas este tipo de avaliação é muito cara, consome muito tempo e há a necessidade de se construir um protótipo do sistema a ser analisado.

À medida que os lançamentos de veículos novos são cada vez mais frequentes há a necessidade de se diminuir o tempo de projeto do veículo (Brown e Jones, 1997). Uma maneira de se diminuir o tempo de projeto de um sistema HVAC é a utilização de sistemas CAE (Computer Aided Engineering) capazes de prever o conforto térmico dentro de um veículo (Brown e Jones, 1997). Com o objetivo de se diminuir os tempos de projeto e implementar sistemas CAE e alcançar o conforto térmico no interior de veículos são necessárias três condições básicas (Hosni et al., 2003b):

a) Modelos para simulação e previsão dos ambientes térmicos em veículos e a resposta do ser humano a estas condições: modelos de conforto térmico.

b) Normas para os métodos de avaliação do conforto térmico em veículos automotivos.

c) Sistemas de controle de HVAC para atingir condições de conforto térmico no interior de veículos.

Ainda segundo Hosni et al. (2003b), um modelo de conforto térmico completo deve incluir:

a) Um modelo físico de troca de calor e um modelo de vestimenta

b) Um modelo de termo-regulação fisiológica do corpo humano.

c) Um modelo de sensação térmica psicológica para prever a resposta de ser humano ao ambiente baseado nas informações dos modelos anteriores.

O problema é que, por enquanto, os modelos desenvolvidos ainda são muito limitados e sem uma validação consistente. Segundo Gameiro da Silva (2002) a única 
forma de se avaliar simultaneamente os efeitos da temperatura do ar local, trocas de calor por radiação do corpo, velocidades do ar e a radiação solar em um veículo é por meio do uso de manequins.

\section{OBJETIVOS E OBJETO DE ESTUDO}

Os objetivos do trabalho são o estudo da utilização de manequins na avaliação de condições de conforto térmico em veículos automotivos e a realização de ensaios em automóveis de passeio.

Os ensaios foram realizados em três automóveis (veículo A, veículo $\mathrm{B}$ e veículo C), modelos standard, com sistema de climatização para avaliação de condições de conforto térmico para condições de verão (resfriamento) e de inverno (aquecimento).

\section{ORGANIZAÇÃO DO TRABALHO}

Inicialmente, no capítulo 2 é apresentada uma revisão sobre a teoria de conforto térmico e de avaliação de ambientes térmicos pelas normas ISO 7730 (1994) e ASHRAE 55 (2004).

No capítulo 3 são discutidos os métodos de avaliação de conforto térmico em ambientes homogêneos e não homogêneos. O método de avaliação de condições de conforto térmico utilizando temperaturas equivalentes é apresentado. São discutidas também outras formas de avaliação do conforto térmico em automóveis, sem a utilização de manequins.

O capítulo 4 trata da avaliação de conforto térmico em automóveis utilizando 
manequins térmicos e manequins com sensores aquecidos. É apresentado o procedimento para determinação de temperaturas equivalentes utilizando manequins, previsto na norma ISO 14505-2 (2004).

No capítulo 5 são apresentados os procedimentos de ensaio utilizando manequim com sensores aquecidos. Inicialmente é feita a descrição do manequim utilizado nos ensaios. Em seguida são apresentados os procedimento de calibração do manequim e os procedimentos de ensaio nas avaliações de condições de conforto térmico nos automóveis.

No capítulo 6 são apresentados os resultados dos ensaios e a análise dos resultados. Inicialmente são apresentadas as condições de ensaio. Depois são apresentados os resultados dos ensaios para condições de verão (resfriamento) e de inverno (aquecimento). Ao final do capítulo é realizada a análise das condições de conforto térmico para condições de verão (resfriamento) e de inverno (aquecimento).

Finalmente, no capítulo 7 são apresentadas as conclusões do trabalho. 


\section{CAPÍTULO 2}

\section{CONFORTO TÉRMICO}

Em muitas situações as pessoas ficam sujeitas a ambientes térmicos criados artificialmente para que se sintam em conforto e possam produzir melhor as suas tarefas. Isto acontece tanto em ambientes de edificações quanto em ambientes de veículos automotivos. Se o objetivo é atingido, a pessoa tem uma sensação de bem estar, expressa pela sua satisfação com aquele ambiente térmico ${ }^{1}$.

O corpo humano gera calor continuamente e a sua temperatura interna deve ser controlada dentro de limites estreitos para evitar o desconforto e o estresse térmico. $\mathrm{O}$ calor gerado (produzido pelo metabolismo) por meio da digestão e da reação química das células, deve ser dissipado para o ambiente de forma a manter a temperatura interna do corpo dentro desses limites.

Em condições térmicas diferentes daquelas na qual a pessoa se sentiria confortável, o organismo provoca reações desencadeadas pelo sistema termorregulador que age no sentido de manter constante a temperatura interna do corpo frente a variações térmicas internas e externas. Esta ação mais intensa do sistema termorregulador acarreta uma sensação de desconforto.

\subsection{O sistema termorregulador}

Em condições normais a temperatura média do corpo é de $37^{\circ} \mathrm{C}$. Dentro de um certo intervalo o sistema de controle de temperatura do corpo humano se esforça para manter esta temperatura frente a perturbações térmicas internas ou externas.

\footnotetext{
${ }^{1}$ Conforto térmico é definido pela ASHRAE 55 (2004) como sendo "um estado de espírito que reflete satisfação com o ambiente térmico que envolve a pessoa".
} 
Mudanças em condições climáticas produzem reações no organismo relacionadas com respostas fisiológicas autônomas, mas também com mudanças de comportamento. As respostas autônomas são controladas pelo hipotálamo, controlando as diferentes formas de perda de calor pelo sangue da pele, suor e respiração. Mudanças de comportamento podem se dar por alteração no nível de atividade, no ajuste da vestimenta e na mudança de posição.

O centro de controle de temperatura do corpo humano está no hipotálamo, que funciona como um termostato. Neuro-receptores termo-sensíveis enviam sinais ao centro de controle e o set-point da temperatura pode mudar durante diferentes condições fisiológicas (Nilsson, 2004).

Em ambientes frios a excitação dos receptores sensíveis ao frio irá baixar o setpoint e a perda de calor pode diminuir por meio de vaso-constrição e de "tremores". Em ambientes quentes, por outro lado, o set-point aumenta e a perda de calor pode aumentar por meio de vaso-dilatação na pele e suor.

Uma pessoa em repouso produz aproximadamente $100 \mathrm{~W}$ de calor. Se a vestimenta e as condições do ambiente estiverem adequadas a mesma quantidade de calor será perdida ao ambiente. Ocorrerá um balanço de calor adequado para o corpo como um todo e a pessoa se sentirá termicamente neutra. Com o aumento da temperatura ambiente, convecção e radiação diminuirão, e a evaporação de suor terá que compensar a perda de calor para restabelecer o equilíbrio entre a geração e a troca de calor de $100 \mathrm{~W}$. Suar é associado com uma sensação de calor e eventualmente desconforto. Em um ambiente mais fresco, convecção e radiação aumentarão, fazendo com que as perdas de calor sejam maiores que $100 \mathrm{~W}$. A resposta fisiológica ocorre para reduzir o fluxo de sangue na pele para diminuir o gradiente térmico externo. Neste caso as pessoas sentirão um pouco de frio ou frio e estarão desconfortáveis.

Uma revisão muito boa do assunto pode ser encontrada em Ferreira (1997) e

Ferreira (2001).

\subsection{Conforto térmico e segurança veicular}

O conforto térmico é um aspecto importante quando se trata de segurança veicular. Motoristas sonolentos devido ao calor, ou com sinais de hipotermia devido ao 
frio, estão mais sujeitos a sofrerem ou causarem acidentes.

A exposição excessiva a um ambiente quente ou frio pode levar ao "stress térmico" (ISO 7243, 1989; ISO 7933, 1989), resultado de condições microclimáticas desfavoráveis que requerem a intervenção excessiva do sistema termorregulador.

A hipotermia pode causar a perda de memória, desorientação, incoerência, fala embaralhada, tontura, exaustão e tremor descontrolado e é um importante fator de morte em acidentes no hemisfério norte (Steen, 2001). A exposição ao calor excessivo causa elevação da temperatura do corpo e sonolência, podendo também levar ao colapso físico.

Conforme apresentado em Ávila (2002), pesquisa financiada pela Nissan Motor Netherland BV e realizada pelo Departamento de Psicologia da Universidade de Amsterdam, mostra que as melhores temperaturas do ar para quem está dirigindo um automóvel vestido "normalmente" se situam entre $18,5^{\circ} \mathrm{C} \leq \mathrm{Ta} \leq 21,5^{\circ} \mathrm{C}$. Nesta faixa de temperaturas, abaixo da condição de conforto, o motorista fica mais atento por estar sentindo um pouco de frio.

\subsection{Balanço térmico do corpo humano}

A temperatura interna do corpo humano é mantida constante somente se ocorrer um equilíbrio entre o calor produzido pelo corpo e o perdido para o ambiente. O homem interage termicamente com o ambiente trocando calor pelos mecanismos da 
condução, convecção, radiação e evaporação. Esta interação do corpo humano com o meio envolvente é apresentada na Figura 2.1.

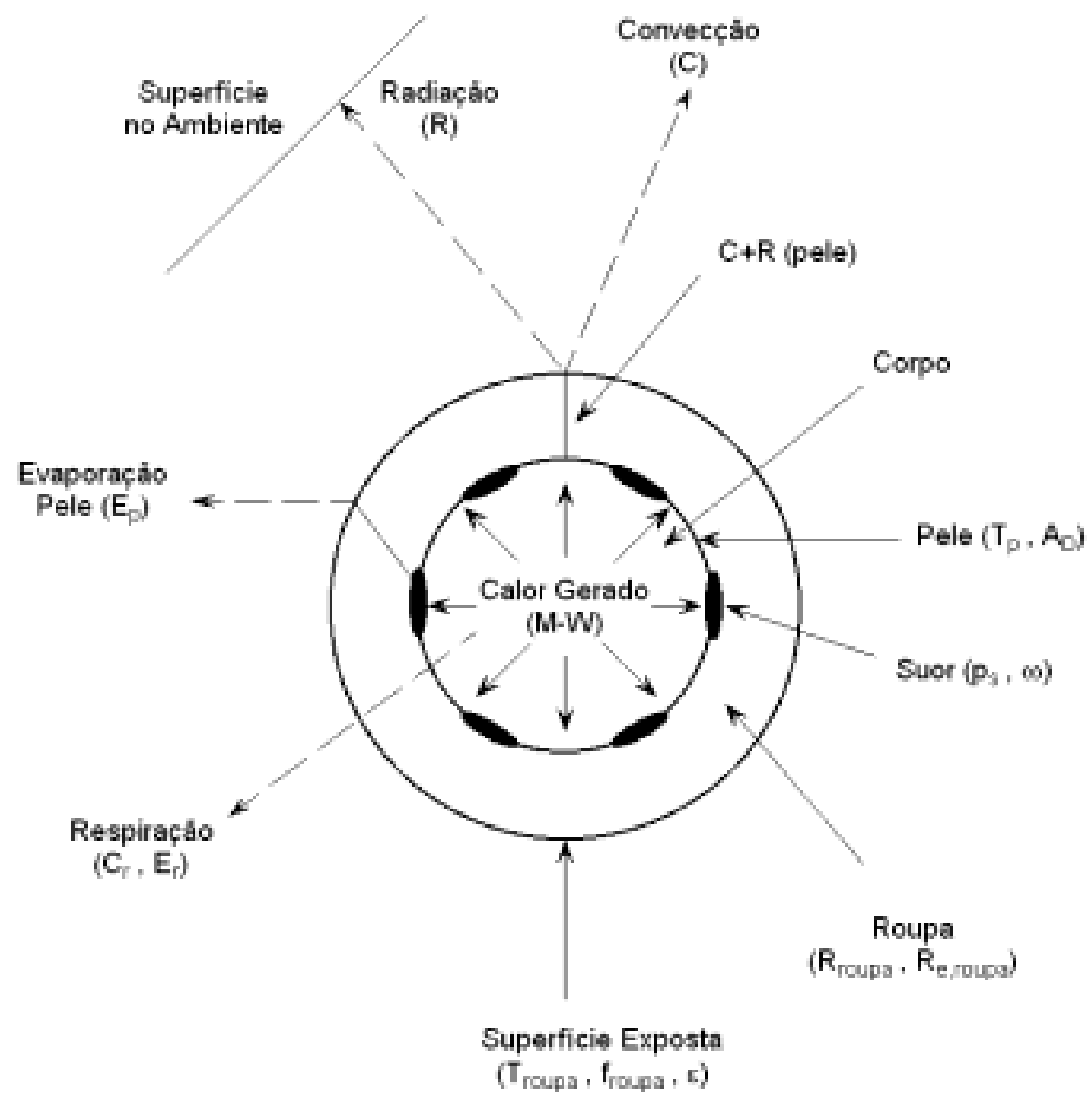

Figura 2.1 Modelo cilíndrico da interação térmica: corpo humano - meio envolvente (ASHRAE, 2001)

Do balanço térmico do corpo humano (1a. lei da termodinâmica), tem-se que:

$$
\mathrm{U}=\mathrm{M}-\mathrm{W}-\mathrm{Q}_{\text {pele }}-\mathrm{Q}_{\text {respiracao }} \quad\left[\mathrm{W} / \mathrm{m}^{2}\right]
$$




$$
\mathrm{U}=\mathrm{M}-\mathrm{W}-\left(\mathrm{C}+\mathrm{R}+\mathrm{E}_{\mathrm{es}}+\mathrm{E}_{\mathrm{dif}}\right)-\left(\mathrm{E}_{\mathrm{R}}+\mathrm{C}_{\mathrm{R}}\right) \quad\left[\mathrm{W} / \mathrm{m}^{2}\right]
$$

onde:

$\begin{array}{clc}\mathrm{U} & \text { taxa de variação de energia interna } & {\left[\mathrm{W} / \mathrm{m}^{2}\right]} \\ \mathrm{M} & \text { Metabolismo } & {\left[\mathrm{W} / \mathrm{m}^{2}\right]} \\ \mathrm{W} & \text { trabalho externo } & {\left[\mathrm{W} / \mathrm{m}^{2}\right]} \\ \mathrm{Q}_{\text {pele }} & \text { calor total perdido pela pele } & {\left[\mathrm{W} / \mathrm{m}^{2}\right]} \\ \mathrm{Q}_{\text {respiração }} & \text { calor total perdido pela respiração } & {\left[\mathrm{W} / \mathrm{m}^{2}\right]} \\ \mathrm{C} & \text { calor perdido pela pele por convecção } & {\left[\mathrm{W} / \mathrm{m}^{2}\right]} \\ \mathrm{R} & \text { calor perdido pela pele por radiação } & {\left[\mathrm{W} / \mathrm{m}^{2}\right]} \\ \mathrm{E}_{\mathrm{es}} & \text { calor perdido pela pele por evaporação de suor } & {\left[\mathrm{W} / \mathrm{m}^{2}\right]} \\ \mathrm{E}_{\mathrm{dif}} & \text { calor perdido pela pele por difusão de vapor d'água } & {\left[\mathrm{W} / \mathrm{m}^{2}\right]} \\ \mathrm{E}_{\mathrm{R}} & \text { calor evaporativo perdido pela respiração } & {\left[\mathrm{W} / \mathrm{m}^{2}\right]} \\ \mathrm{C}_{\mathrm{R}} & \text { calor convectivo perdido pela respiração } & {\left[\mathrm{W} / \mathrm{m}^{2}\right]}\end{array}$

Do balanço térmico do corpo humano e aplicando-se as equações que descrevem os mecanismos de transferência de calor, são obtidas as variáveis de conforto térmico (Fanger, 1972):

a) Parâmetros individuais: o tipo de atividade $(\mathrm{M}, \mathrm{W})$ e a isolação da vestimenta $\left(\mathrm{I}_{\mathrm{R}}\right)$; b) Parâmetros do ambiente: a temperatura do ar ambiente $\left(\mathrm{T}_{\mathrm{ar}}\right)$; a 
temperatura radiante média $\left(\bar{T}_{r}\right)$; a velocidade do ar $\left(\mathrm{V}_{\mathrm{ar}}\right)$ e a umidade relativa do ar $(\phi)$.

\subsection{Equação de conforto de Fanger}

Fanger (1972) estabeleceu três condições para que uma pessoa estivesse em condição de conforto térmico exposta a um dado ambiente por um período longo:

a) A primeira condição é que haja equilíbrio das trocas de calor entre o corpo e o ambiente, isto é,

$$
\mathbf{U}=\mathbf{0}
$$

b) A segunda condição é que a temperatura média da pele $\left(T_{p}\right)$ seja dada pela equação:

$$
T_{p}=35,7-0,0275(M-W)
$$

c) A terceira condição é que a produção de suor $\left(\mathrm{E}_{\mathrm{es}}\right)$ seja igual a:

$$
\text { Ees } \quad=0,42 \quad(M \quad-\quad W \quad-\quad 58,2)
$$

\section{(2.5)}

As equações (2.4) e (2.5) foram obtidas a partir de dados experimentais levantados em ensaios com 1300 pessoas. Inserindo as Eqs. 2.3 a 2.5, juntamente com as equações de transferência de calor, na Eq. (2.2), obtém-se a equação de conforto de 
Fanger (Fanger, 1972), dada por:

$$
\begin{aligned}
M-\mathrm{W}= & 0,42[\mathrm{M}-\mathrm{W}-58,2]+3,05\left[5,73-0,007(M-W)-p_{v_{a r}}\right]+ \\
& +0,0173\left(5,87-p_{v_{\text {ar }}}\right)+0,0014 M\left(34-T_{a r}\right)+f_{R} h_{c}\left(T_{\text {roupa }}-T_{a r}\right)+ \\
& +3,96 \times 10^{-8} f_{R}\left[\left(T_{\text {roupa }}+273\right)^{4}-\left(\bar{T}_{r}+273\right)^{4}\right]
\end{aligned}
$$

com:

$$
\mathrm{T}_{\text {roupa }}=35,7-0,0275(\mathrm{M}-\mathrm{W})-0,155 \operatorname{Iroupa}\left\{\begin{array}{l}
(\mathrm{M}-\mathrm{W})-3,05\left[5,73-0,007(\mathrm{M}-\mathrm{W})-\mathrm{p}_{\mathrm{v}_{\mathrm{ar}}}\right]+ \\
-0,42(\mathrm{M}-\mathrm{W}-58,2)-0,0173 \mathrm{M}\left(5,87-\mathrm{p}_{\mathrm{v}_{\mathrm{ar}}}\right)+ \\
-0,0014 \mathrm{M}\left(34-\mathrm{T}_{\mathrm{ar}}\right)
\end{array}\right\}
$$

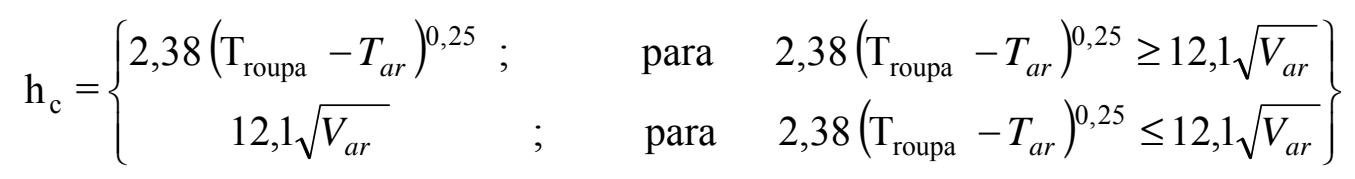

$$
\mathrm{f}_{\mathrm{R}}=\left\{\begin{array}{cccc}
1,0+0,2 \mathrm{I}_{\mathrm{R}} & ; & \text { para } & \mathrm{I}_{\mathrm{R}} \leq 0,5 C L O \\
1,05+0,1 \mathrm{I}_{\mathrm{R}} & ; & \text { para } \mathrm{I}_{\mathrm{R}} \geq 0,5 \mathrm{CLO}
\end{array}\right\}
$$


onde:

$$
\begin{aligned}
\mathrm{M} & =\text { metabolismo }\left(\mathrm{W} / \mathrm{m}^{2}\right) \\
\mathrm{W} & =\text { trabalho externo }\left(\mathrm{W} / \mathrm{m}^{2}\right) \\
\mathrm{I}_{\mathrm{R}} & =\text { índice de isolamento da roupa }(\mathrm{clo}) \\
\mathrm{T}_{\mathrm{ar}} & =\text { temperatura do } \operatorname{ar}\left({ }^{\circ} \mathrm{C}\right) \\
\mathrm{V}_{\mathrm{ar}} & =\text { velocidade média do ar }(\mathrm{m} / \mathrm{s}) \\
\mathrm{p}_{\mathrm{var}} & =\text { pressão parcial do vapor d'água no ambiente }(\mathrm{kPa}) \\
\bar{T}_{r} & =\text { temperatura média radiante }\left({ }^{\circ} \mathrm{C}\right)
\end{aligned}
$$

A equação 2.6 relaciona os fatores pessoais $\left(M, W, I_{R}\right)$ e ambientais $\left(T_{a r}, V_{a r}\right.$, $\left.\mathrm{p}_{\mathrm{var}}, \bar{T}_{r}\right)$ para conforto térmico

O metabolismo, função da atividade, normalmente é expresso em termos de unidades de metabolismo met $^{2}$. Na Tabela 2.1 são apresentados valores de metabolismo para diferentes atividades.

Tabela 2.1 - Metabolismos para diferentes atividades (www.hku.hk/bse/bbse3004/)

\begin{tabular}{|l|c|c|}
\hline \multicolumn{1}{|c|}{ Atividade } & \multicolumn{2}{c|}{ Taxa metabólica } \\
\hline Sentado reclinado & $46 \mathrm{~W} / \mathrm{m}^{2}$ & 0,8 met \\
\hline Sentado relaxado & $58 \mathrm{~W} / \mathrm{m}^{2}$ & 1,0 met \\
\hline Reparador de relógios & $65 \mathrm{~W} / \mathrm{m}^{2}$ & $1,1 \mathrm{met}$ \\
\hline Em pé relaxado & $70 \mathrm{~W} / \mathrm{m}^{2}$ & $1,2 \mathrm{met}$ \\
\hline Dirigindo carro & $80 \mathrm{~W} / \mathrm{m}^{2}$ & 1,4 met \\
\hline Em pé, atividade leve & $93 \mathrm{~W} / \mathrm{m}^{2}$ & 1,6 met \\
\hline Caminhando horizontalmente $(2 \mathrm{~km} / \mathrm{h})$ & $110 \mathrm{~W} / \mathrm{m}^{2}$ & 1,9 met \\
\hline Em pé, atividades moderadas $($ trabalho doméstico) & $116 \mathrm{~W} / \mathrm{m}^{2}$ & 2,0 met \\
\hline Caminhando horizontalmente, $5 \mathrm{~km} / \mathrm{h}$ & $200 \mathrm{~W} / \mathrm{m}^{2}$ & 3,4 met \\
\hline
\end{tabular}

$21 \mathrm{met}=58,2 \mathrm{~W} / \mathrm{m}^{2}$ (atividade sedentária) 


\begin{tabular}{|l|c|c|}
\hline Trabalhadores da construção civil & $275 \mathrm{~W} / \mathrm{m}^{2}$ & $4,7 \mathrm{met}$ \\
\hline Esportes - correndo a $15 \mathrm{~km} / \mathrm{h}$ & $550 \mathrm{~W} / \mathrm{m}^{2}$ & $9,5 \mathrm{met}$ \\
\hline
\end{tabular}

A vestimenta representa uma resistência à troca de calor entre o corpo e o meio, e portanto, afeta o equilíbrio térmico. A resistência térmica da roupa $\left(I_{R}\right)$ é normalmente representada pela unidade $\mathrm{clo}^{3}$.

Uma vestimenta leve (calça comprida, camisa de manga curta, sapato e meia), apresenta um clo em torno de 0,5. Em atividades de escritório, no Brasil, a vestimenta mais usual é a calça comprida, camisa de manga comprida, gravata, sapato e meia, que corresponde a um clo em torno de 0,6 (Leite, 2003). Este valor de clo também é aquele da vestimenta nos ensaios de resfriamento (Capítulos 5 e 6 )

Já uma vestimenta mais pesada, de inverno, com calça comprida, camisa de manga comprida, gravata, sapato, meia e paletó assume valores em torno de 1,0 clo; que é o valor de clo da vestimenta nos ensaios de aquecimento (Capítulos 5 e 6 ).

Para a obtenção das variáveis ambientais: velocidade média do ar, $\mathrm{V}_{\mathrm{ar}}$, temperatura média radiante, $\bar{T}_{r}$, temperatura do ar, $\mathrm{T}_{\mathrm{ar}}$ e umidade do ar: umidade absoluta, $\omega$, e umidade relativa, $\phi$, são realizadas medições no ambiente. A norma ISO 7726 (1996) apresenta procedimentos de medição e métodos para a determinação destas variáveis ambientais.

\subsection{Avaliação de ambientes térmicos}

\footnotetext{
${ }^{3} 1$ clo $=0,155 \mathrm{~m}^{2}{ }^{\circ} \mathrm{C} / \mathrm{W}$ (vestimenta típica de inverno, pesada)
} 
No item anterior foi apresentada a equação de conforto de Fanger (Eq. 2.6). que trata de situações de conforto térmico, isto é, das combinações dos parâmetros (M, $\mathrm{W}, \mathrm{I}_{\mathrm{R}}, \mathrm{T}_{\mathrm{ar}}, \mathrm{V}_{\mathrm{ar}}, \mathrm{p}_{\mathrm{var}}, \bar{T}_{r}$ ) que causam conforto térmico. A sensação de conforto em um ambiente térmico, contudo, depende das pessoas.

Assim, há a necessidade de uma avaliação das pessoas quanto às condições de conforto que o ambiente térmico proporciona. Esta avaliação subjetiva, normalmente, é realizada por meio do voto das pessoas segundo critérios definidos na escala de sensação térmica da ASHRAE, apresentada na Tabela 2.2.

Tabela 2.2 - Escala de sensação térmica da ASHRAE (ASHRAE, 2001)

\begin{tabular}{|c|c|}
\hline+3 & muito quente \\
\hline+2 & Quente \\
\hline+1 & ligeiramente quente \\
\hline 0 & Neutro \\
\hline-1 & ligeiramente frio \\
\hline-2 & Frio \\
\hline-3 & muito frio \\
\hline
\end{tabular}

\subsubsection{Voto médio estimado (PMV)}

Nos ensaios realizados por Fanger, as pessoas, desempenhando uma certa atividade (metabolismo, M) e vestindo uma certa roupa (clo), eram colocadas em câmaras climatizadas (com determinadas condições ambientais) e davam os seus votos quanto à sensação que percebiam. Destes votos resultou a equação do voto médio estimado (PMV - Predicted Mean Vote) que correlaciona as variáveis pessoais ((M, W, 
$\left.\mathrm{I}_{\mathrm{R}}\right)$, as variáveis ambientais $\left(\mathrm{T}_{\mathrm{ar}}, \mathrm{V}_{\mathrm{ar}}, \mathrm{p}_{\mathrm{var}}, \bar{T}_{r}\right)$ e o voto (sensação) das pessoas.

O trabalho de Fanger (Fanger, 1972) é a base da norma ISO 7730 (1994) de conforto térmico. Uma vez que o cálculo do voto médio estimado (PMV) é um pouco trabalhoso, Fanger (1972) e a ISO 7730 (1994) apresentam tabelas, como aquela da Tabela 2.3, e uma rotina para utilização em microcomputador, que permitem determinar o PMV para diferentes atividades, tipos de vestimenta e condições ambientais.

A ASHRAE 55 (ASHRAE, 2004) também apresenta gráficos para a determinação das condições de conforto térmico em ambientes condicionados - as Cartas de Conforto da ASHRAE. Na Figura 2.2 mostra-se uma carta psicrométrica com a zona de conforto representada pela área hachurada.

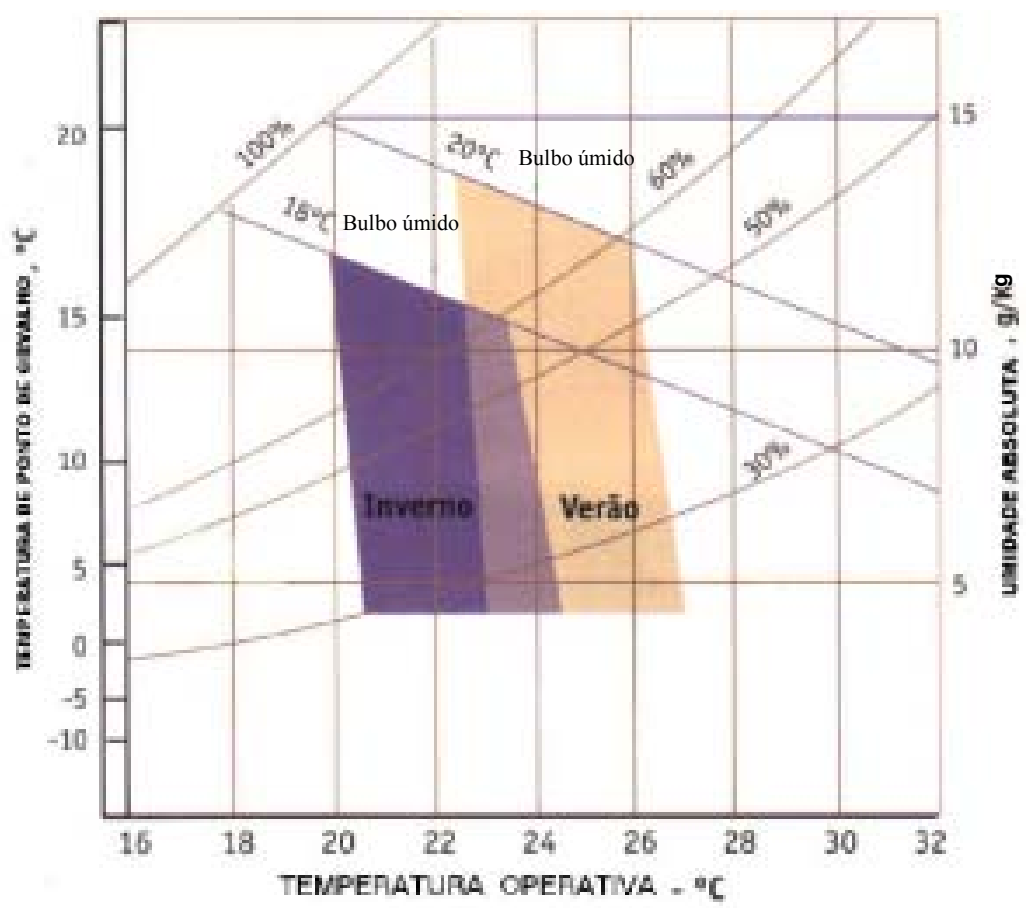

Figura 2.2 Diagrama psicrométrico com a indicação da zona de conforto em ambientes climatizados segundo a norma ASHRAE 55 (2004). 
Tabela 2.3 Determinação do voto médio estimado - PMV (ISO 7730, 1994) Atividade sedentária $(\mathrm{MET}=1.0)$ e umidade relativa do ar de $50 \%$

\begin{tabular}{|c|c|c|c|c|c|c|c|c|c|c|}
\hline \multicolumn{2}{|c|}{ Vestimenta } & \multirow{2}{*}{$\begin{array}{c}\text { Temperatu } \\
\text { ra } \\
\begin{array}{c}\text { Operativa } \\
{ }^{\circ} \mathrm{C}\end{array}\end{array}$} & \multicolumn{8}{|c|}{ Velocidade Relativa do ar - m/s } \\
\hline $\mathrm{CLO}$ & $\frac{\mathbf{m}^{20} \mathrm{C}}{W}$ & & $<0.10$ & 0.10 & 0.15 & 0.20 & 0.30 & 0.40 & 0.50 & 1.00 \\
\hline 0 & 0 & $\begin{array}{l}26 \\
27 \\
28 \\
29 \\
30 \\
31 \\
32 \\
33\end{array}$ & $\begin{array}{r}-1.62 \\
-1.00 \\
-0.39 \\
0.21 \\
0.80 \\
1.39 \\
1.96 \\
2.50\end{array}$ & $\begin{array}{r}-1.62 \\
-1.00 \\
-0.42 \\
0.13 \\
0.68 \\
1.25 \\
1.83 \\
2.41\end{array}$ & $\begin{array}{r}-1.96 \\
-1.36 \\
-0.76 \\
-0.15 \\
0.45 \\
1.08 \\
1.71 \\
2.34\end{array}$ & $\begin{array}{r}-2.34 \\
-1.69 \\
-1.05 \\
-0.39 \\
0.26 \\
0.94 \\
1.61 \\
2.29\end{array}$ & & & & \\
\hline 0.25 & 0.039 & $\begin{array}{l}24 \\
25 \\
26 \\
27 \\
28 \\
29 \\
30 \\
31\end{array}$ & $\begin{array}{r}-1.52 \\
-1.05 \\
-0.58 \\
-0.12 \\
0.34 \\
0.80 \\
1.25 \\
1.71\end{array}$ & $\begin{array}{r}-1.52 \\
-1.05 \\
-0.61 \\
-0.17 \\
0.27 \\
0.71 \\
1.15 \\
1.61\end{array}$ & $\begin{array}{r}-1.80 \\
-1.33 \\
-0.87 \\
-0.40 \\
0.07 \\
0.54 \\
1.02 \\
1.51\end{array}$ & $\begin{array}{r}-2.06 \\
-1.57 \\
-1.08 \\
-0.58 \\
-0.09 \\
0.41 \\
0.91 \\
1.43\end{array}$ & $\begin{array}{r}-2.47 \\
-1.94 \\
-1.41 \\
-0.87 \\
-0.34 \\
0.20 \\
0.74 \\
1.30\end{array}$ & $\begin{array}{r}-2.24 \\
-1.67 \\
-1.10 \\
-0.53 \\
0.04 \\
0.61 \\
1.20\end{array}$ & $\begin{array}{r}-2.48 \\
-1.89 \\
-1.29 \\
-0.70 \\
-0.10 \\
0.50 \\
1.12\end{array}$ & $\begin{array}{r}-2.66 \\
-1.97 \\
-1.28 \\
-0.58 \\
0.11 \\
0.83\end{array}$ \\
\hline 0.50 & 0.078 & $\begin{array}{l}23 \\
24 \\
25 \\
26 \\
27 \\
28 \\
29 \\
30\end{array}$ & $\begin{array}{r}-1.10 \\
-0.72 \\
-0.34 \\
0.04 \\
0.42 \\
0.80 \\
1.17 \\
1.54\end{array}$ & $\begin{array}{r}-1.10 \\
-0.74 \\
-0.38 \\
-0.01 \\
0.35 \\
0.72 \\
1.08 \\
1.45\end{array}$ & $\begin{array}{r}-1.33 \\
-0.95 \\
-0.56 \\
-0.18 \\
0.20 \\
0.59 \\
0.98 \\
1.37\end{array}$ & $\begin{array}{r}-1.51 \\
-1.11 \\
-0.71 \\
-0.31 \\
0.09 \\
0.49 \\
0.90 \\
1.30\end{array}$ & $\begin{array}{r}-1.78 \\
-1.36 \\
-0.94 \\
-0.51 \\
-0.08 \\
0.34 \\
0.77 \\
1.20\end{array}$ & $\begin{array}{r}-1.99 \\
-1.55 \\
-1.11 \\
-0.66 \\
-0.22 \\
0.23 \\
0.68 \\
1.13\end{array}$ & $\begin{array}{r}-2.16 \\
-1.70 \\
-1.25 \\
-0.79 \\
-0.33 \\
0.14 \\
0.60 \\
1.06\end{array}$ & $\begin{array}{r}-2.22 \\
-1.71 \\
-1.19 \\
-0.68 \\
-0.17 \\
0.34 \\
0.86\end{array}$ \\
\hline 0.75 & 0.118 & $\begin{array}{l}21 \\
22 \\
23 \\
24 \\
25 \\
26 \\
27 \\
28\end{array}$ & $\begin{array}{r}-1.11 \\
-0.79 \\
-0.47 \\
-0.15 \\
0.17 \\
0.49 \\
0.81 \\
1.12\end{array}$ & $\begin{array}{r}-1.11 \\
-0.81 \\
-0.50 \\
-0.19 \\
0.12 \\
0.43 \\
0.74 \\
1.05\end{array}$ & $\begin{array}{r}-1.30 \\
-0.96 \\
-0.66 \\
-0.33 \\
-0.01 \\
0.31 \\
0.64 \\
0.96\end{array}$ & $\begin{array}{r}-1.44 \\
-1.11 \\
-0.78 \\
-0.44 \\
-0.11 \\
0.23 \\
0.56 \\
0.90\end{array}$ & $\begin{array}{r}-1.66 \\
-1.31 \\
-0.96 \\
-0.61 \\
-0.28 \\
0.09 \\
0.45 \\
0.80\end{array}$ & $\begin{array}{r}-1.82 \\
-1.46 \\
-1.09 \\
-0.73 \\
-0.37 \\
0.00 \\
0.36 \\
0.73\end{array}$ & $\begin{array}{r}-1.95 \\
-1.58 \\
-1.20 \\
-0.83 \\
-0.46 \\
-0.08 \\
0.29 \\
0.67\end{array}$ & $\begin{array}{r}-2.36 \\
-1.95 \\
-1.55 \\
-1.14 \\
-0.74 \\
-0.33 \\
0.08 \\
0.48\end{array}$ \\
\hline 1.00 & 0.155 & $\begin{array}{l}20 \\
21 \\
22 \\
23 \\
24 \\
25 \\
26 \\
27\end{array}$ & $\begin{array}{r}-0.85 \\
-0.57 \\
-0.30 \\
-0.02 \\
0.26 \\
0.53 \\
0.81 \\
1.08\end{array}$ & $\begin{array}{r}-0.87 \\
-0.60 \\
-0.33 \\
-0.07 \\
0.20 \\
0.48 \\
0.75 \\
1.02\end{array}$ & $\begin{array}{r}-1.02 \\
-0.74 \\
-0.46 \\
-0.18 \\
0.10 \\
0.38 \\
0.66 \\
0.95\end{array}$ & $\begin{array}{r}-1.13 \\
-0.84 \\
-0.55 \\
-0.27 \\
0.02 \\
0.31 \\
0.60 \\
0.89\end{array}$ & $\begin{array}{r}-1.29 \\
-0.99 \\
-0.69 \\
-0.39 \\
-0.09 \\
0.21 \\
0.51 \\
0.81\end{array}$ & $\begin{array}{r}-1.41 \\
-1.11 \\
-0.80 \\
-0.49 \\
-0.18 \\
0.13 \\
0.44 \\
0.75\end{array}$ & $\begin{array}{r}-1.51 \\
-1.19 \\
-0.88 \\
-0.56 \\
-0.25 \\
0.07 \\
0.39 \\
0.71\end{array}$ & $\begin{array}{r}-1.81 \\
-1.47 \\
-1.13 \\
-0.79 \\
-0.46 \\
-0.12 \\
0.22 \\
0.56\end{array}$ \\
\hline 1.50 & 0.233 & $\begin{array}{l}14 \\
16 \\
18 \\
20 \\
22 \\
24 \\
26 \\
28\end{array}$ & $\begin{array}{r}-1.36 \\
-0.94 \\
-0.52 \\
-0.09 \\
0.35 \\
0.79 \\
1.23 \\
1.67\end{array}$ & $\begin{array}{r}-1.36 \\
-0.95 \\
-0.54 \\
-0.13 \\
0.30 \\
0.74 \\
1.18 \\
1.62\end{array}$ & $\begin{array}{r}-1.48 \\
-1.07 \\
-0.64 \\
-0.22 \\
0.23 \\
0.68 \\
1.13 \\
1.56\end{array}$ & $\begin{array}{r}-1.58 \\
-1.15 \\
-0.72 \\
-0.28 \\
0.18 \\
0.63 \\
1.09 \\
1.56\end{array}$ & $\begin{array}{r}-1.72 \\
-1.27 \\
-0.82 \\
-0.37 \\
0.10 \\
0.57 \\
1.04 \\
1.52\end{array}$ & $\begin{array}{r}-1.82 \\
-1.36 \\
-0.90 \\
-0.44 \\
0.04 \\
0.52 \\
1.01 \\
1.48\end{array}$ & $\begin{array}{r}-1.89 \\
-1.43 \\
-0.96 \\
-0.49 \\
0.00 \\
0.49 \\
0.98 \\
1.47\end{array}$ & $\begin{array}{r}-2.12 \\
-1.63 \\
-1.14 \\
-0.65 \\
-0.14 \\
0.37 \\
0.89 \\
1.40\end{array}$ \\
\hline 2.00 & 0.310 & $\begin{array}{l}10 \\
12 \\
14 \\
16 \\
18 \\
20 \\
22 \\
24\end{array}$ & $\begin{array}{r}-1.38 \\
-1.03 \\
-0.68 \\
-0.32 \\
0.03 \\
0.40 \\
0.76 \\
1.13\end{array}$ & $\begin{array}{r}-1.39 \\
-1.05 \\
-0.70 \\
-0.35 \\
-0.00 \\
0.36 \\
0.72 \\
1.09\end{array}$ & $\begin{array}{r}-1.49 \\
-1.14 \\
-0.79 \\
-0.43 \\
-0.07 \\
0.30 \\
0.67 \\
1.05\end{array}$ & $\begin{array}{r}-1.56 \\
-1.21 \\
-0.85 \\
-0.48 \\
-0.11 \\
0.26 \\
0.54 \\
1.02\end{array}$ & $\begin{array}{r}-1.67 \\
-1.30 \\
-0.93 \\
-0.56 \\
-0.18 \\
0.20 \\
0.59 \\
0.98\end{array}$ & $\begin{array}{r}-1.74 \\
-1.37 \\
-0.99 \\
-0.61 \\
-0.23 \\
0.16 \\
0.55 \\
0.95\end{array}$ & $\begin{array}{r}-1.80 \\
-1.42 \\
-1.04 \\
-0.65 \\
-0.26 \\
0.13 \\
0.53 \\
0.93\end{array}$ & $\begin{array}{r}-1.96 \\
-1.57 \\
-1.17 \\
-0.77 \\
-0.37 \\
0.04 \\
0.45 \\
0.87\end{array}$ \\
\hline
\end{tabular}


OBS: 1) Valores de PMV em torno de zero indicam condições de conforto térmico.

2) Valores de CLO igual a 0,5 representam uma vestimenta leve de verão (calça comprida com camisa de mangas curtas), enquanto valores de CLO igual a 1,0 representam uma vestimenta pesada de inverno.

Verifica-se na Tabela 2.3 e na Figura 2.2 que os resultados são apresentados em função da temperatura operativa, $T_{o}^{4}$, que é função da temperatura média radiante, $\bar{T}_{r}, e$ da temperatura do ar, $T_{a r}$, dado pela equação $2.10^{5}$ :

$$
T_{o}=a \cdot T_{a r}+(1-a) \cdot \bar{T}_{r}
$$

onde a constante $\boldsymbol{a}$ varia de acordo com a velocidade do ar $\left(V_{A R}\right)$ :

$$
\begin{array}{cccc}
V_{a r}(\mathrm{~m} / \mathrm{s}) & 0-0,2 & 0,2-0,6 & 0,6-1,0 \\
a & 0,5 & 0,6 & 0,7
\end{array}
$$

\subsubsection{Percentagem de pessoas insatisfeitas (PPD)}

Os valores de PMV não são suficientes para definir a sensação de desconforto, pois, "ligeiramente frio ou quente" ou qualquer outro valor da escala, não indicam o quão insatisfeitas as pessoas estão. Para isto, Fanger (1972), associou aos índices de voto médio estimado (PMV) com a percentagem de pessoas insatisfeitas (PPD -

\footnotetext{
${ }^{4} \mathrm{~T}_{\mathrm{o}}=$ temperatura operativa $\left({ }^{\circ} \mathrm{C}\right)$ : a temperatura de um meio imaginário (envolvendo ar e superfícies) com o qual a pessoa troca a mesma quantidade de calor por convecção e radiação que aquela trocada com o meio real.
}

\footnotetext{
${ }^{5}$ ANSI/ASHRAE 55 (2004) e ISO 7730 (1994).
} 
Predicted Percentage of Dissatisfied).

Na Figura 2.3 é mostrada a relação entre PMV e PPD. Verifica-se nesta figura que, mesmo com PMV igual a zero (neutralidade térmica), 5\% estão insatisfeitos.

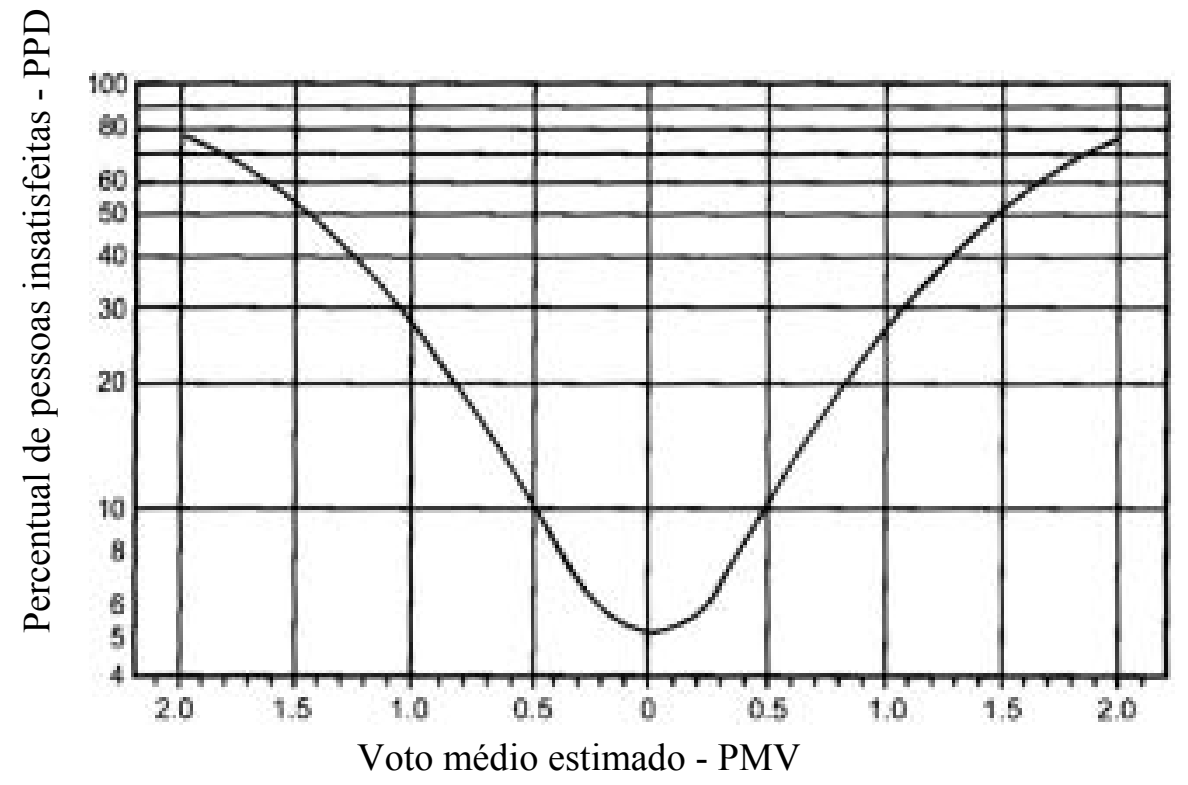

Figura 2.3 Relação entre PMV e PPD

\subsubsection{DESCONFORTO TÉRMICO LOCAL}

As condições de conforto térmico de Fanger foram obtidas para o corpo como um todo. Contudo, uma pessoa pode sentir neutralidade térmica $(\mathrm{PMV}=0)$, mas pode não estar confortável se uma parte do corpo está "quente" e uma outra "fria". Portanto, para se ter condições de conforto é necessário também que não haja desconforto local (quente ou frio) em diferentes partes do corpo.

Este desconforto térmico local pode ser causado por:

Correntes de ar ("draft" ou "draught"); 
Assimetria de radiação;

$>$ Diferença de temperatura vertical do ar entre os pés e a cabeça;

$>$ Diferença de temperatura entre os pés e o piso.

Limites máximos previstos para cada uma das causas de desconforto térmico local são apresentados nas normas ASHRAE 55 ( 2004) e ISO 7730 (1994). 


\section{CAPÍTULO 3}

\section{AVALIAÇÃO DE CONFORTO TÉRMICO EM VEÍCULOS AUTOMOTIVOS}

Pode-se dizer, de uma forma geral, que existem dois tipos de métodos para avaliar condições de conforto térmico. Estes métodos dependem do meio ser homogêneo ou não (Nilsson, 2004):

A. Ambientes homogêneos: Em residências e em ambientes de edificações ocorrem condições relativamente homogêneas de temperatura, velocidade do ar, umidade e radiação térmica. O método de Fanger, visto no Capítulo 2, foi desenvolvido para avaliação de conforto nestes tipos de ambientes. Os índices PMV e PPD foram obtidos para condições de regime permanente, mas podem ser aplicados com boa aproximação se ocorrerem "flutuações pequenas" de uma ou mais variáveis. Além disto, para levar em conta efeitos de correntes de ar (drafts)), Fanger et al. (1988) introduziram um índice complementar, o índice PD (Percentage of Dissatisfied).

B. Ambientes não homogêneos: Nos veículos automotivos, normalmente, ocorrem gradientes de temperatura e velocidade do ar significativos, com grandes assimetrias de temperatura, velocidade do ar e temperaturas radiantes, mesmo em condições de regime permanente. Em um automóvel, por exemplo, as saídas de ar geralmente são pequenas e o espaço confinado prejudica a circulação do ar. Além disso, há uma grande incidência solar e uma isolação adicional devido aos bancos. Em função disto, o uso dos índices PMV (ISO 7730) ou das cartas da ASHRAE (ASHRAE 55) não são os mais apropriados (Madsen et al., 1986; Gameiro da Silva, 2002; Hosni et al., 2003; Nilsson, 2004). 


\subsection{Avaliação de conforto térmico em ambientes não homogêneos}

Para ambientes não homogêneos, onde diferentes partes do corpo experimentam diferentes condições térmicas, o conceito mais amplamente utilizado (Nilsson, 2004) é o de temperatura equivalente $\left(t_{\mathrm{eq}}\right)$, definida como sendo a temperatura uniforme de um ambiente imaginário com velocidade do ar igual a zero, no qual a pessoa troca a mesma quantidade de calor sensível, por radiação e convecção, que no ambiente real.

Desde 1932, quando Duffon (1932) apud Gameiro da Silva (2002) propôs medir temperatura equivalente utilizando manequim, modernos e sofisticados métodos de medir temperatura equivalente têm sido propostos: Madsen (1976); Wyon et al (1985); Madsen et al (1986) e Olesen (1988) apud Gameiro da Silva (2002).

Dentre as equações para o cálculo de temperatura equivalente, $t_{\mathrm{eq}}$, em ambientes internos, o equacionamento apresentado por Madsen et al. (1984), função das variáveis ambientais $\left(\mathrm{T}_{\mathrm{ar}}, \mathrm{V}_{\mathrm{ar}}, \bar{T}_{r}\right)$ e da vestimenta $\left(\mathrm{I}_{\mathrm{R}}\right)$ é mais utilizado, onde:

$$
\begin{array}{cc}
t_{e q}=0,55 \mathrm{~T}_{\mathrm{ar}}+0,45 \overline{\mathrm{T}}_{\mathrm{r}}+\frac{0,24-0,75 \sqrt{\mathrm{V}_{\mathrm{ar}}}}{1+\mathrm{I}_{\mathrm{R}}}\left(36,5-\mathrm{T}_{\mathrm{ar}}\right) & (\text { Var }>0,1 \mathrm{~m} / \mathrm{s}) \\
t_{e q}=T_{o}=\frac{T_{a r}+\bar{T}_{r}}{2} & (\text { Var } \leq 0,1 \mathrm{~m} / \mathrm{s})
\end{array}
$$

e $T_{o}$ é a temperatura operativa (ver Cap. 2, Eq. 2.10).

Em alguns trabalhos da literatura aparecem algumas variações com relação à denominação da temperatura equivalente: ELT - equivalent living-room temperature (temperatura equivalente do "ambiente") e EHT - equivalent homogeneous temperature (temperatura equivalente homogênea), mas o conceito é o mesmo. 


\title{
3.2 Avaliação de conforto térmico em automóveis
}

\author{
Atualmente, o índice de conforto térmico mais utilizado pela indústria \\ automobilística também é a temperatura equivalente (Gameiro da Silva, 2002; \\ Martinho, Silva e Ramos, 2004; Nilsson, 2004). A utilização deste índice na avaliação \\ de condições de conforto térmico em automóveis, com a utilização de manequins, será \\ vista em detalhes no Capítulo 4.
}

No presente capítulo serão discutidos brevemente alguns outros trabalhos, utilizando diferentes técnicas de avaliação de condições de conforto em automóveis.

\subsection{1 - Avaliação de conforto térmico realizado pelas empresas montadoras.}

Muitos dos métodos de avaliação utilizados pela indústria automobilística são desenvolvidos pelos próprios fabricantes (montadoras) e seguem critérios e procedimentos próprios para cada montadora.

Esta diversidade de técnicas de avaliação de conforto térmico resulta em um sem número de padrões e critérios utilizados, o que traz problemas para os fornecedores de sistemas de climatização veicular. Assim, como forma de uniformizar o critério de avaliação de conforto em automóveis, pesquisadores da Delphi (Han e Huang, 2004) desenvolveram um método baseado na temperatura equivalente homogênea (EHT) e em um modelo fisiológico do corpo humano. Neste modelo o corpo é dividido em 16 segmentos compostos por quatro camadas (núcleo, músculo, gordura, e pele) e uma camada de roupa. Na Figura 3.1 é apresentada uma 
representação esquemática do problema analisado.

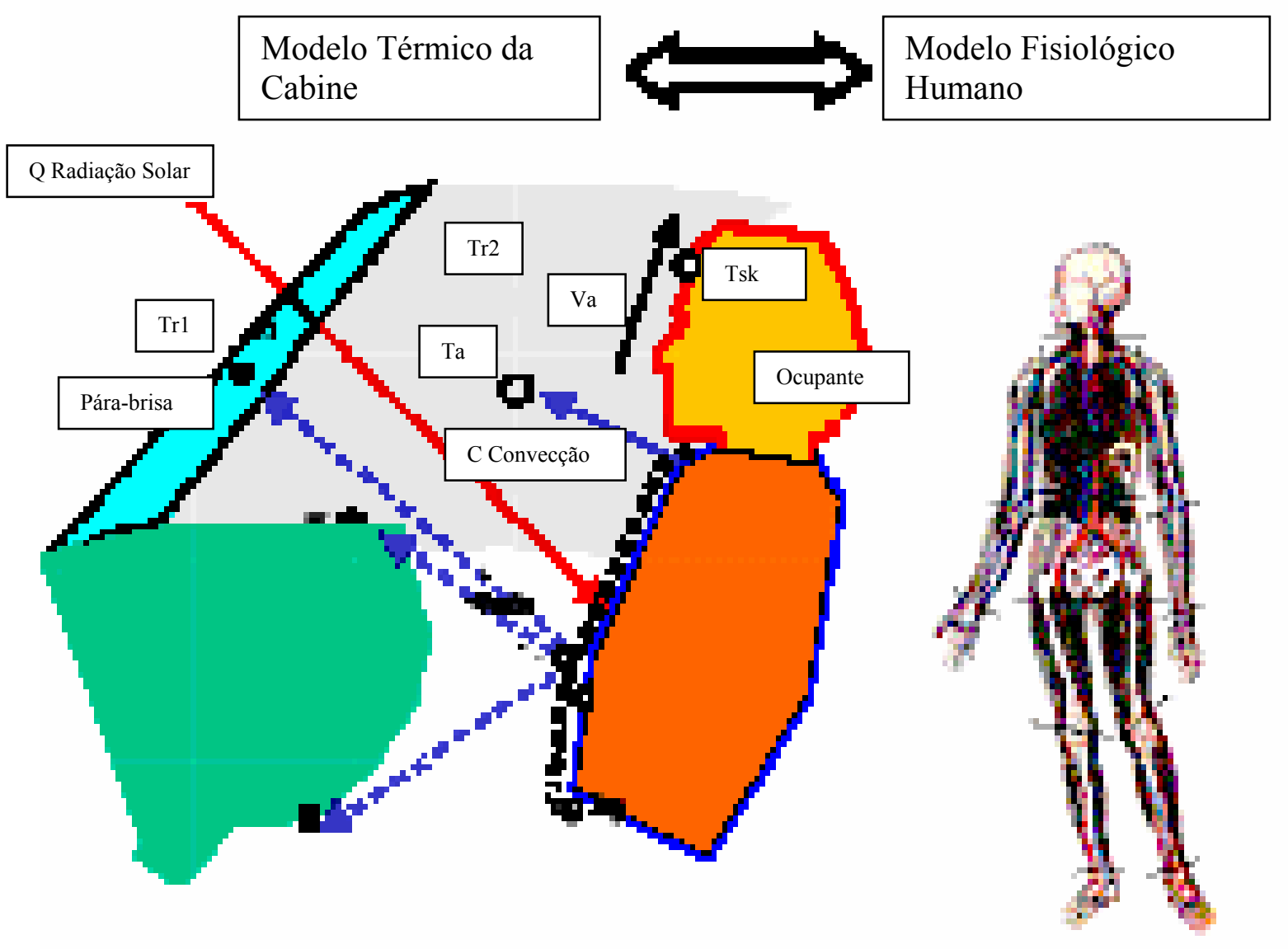

Figura 3.1 - Representação esquemática do problema analisado (Han e Huang, 2004).

A representação dos índices EHT para os 16 segmentos do corpo (Fig. 3.2) do trabalho de Han e Huang (2004) é apresentada de forma similar aos valores de $t_{e q}$ na norma ISO 14505 (ISO, 2004); discutidos no Capítulo 4.

Segundo Han e Huang (2004), os resultados do modelo para EHT foram comparados corm dados de testes subjetivos durante ensaios realizados pelas

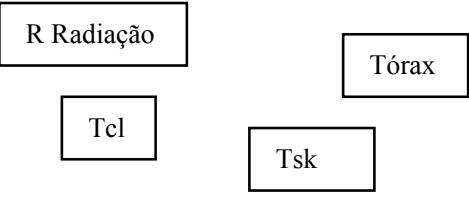


montadoras com 16 pessoas (qualificadas) e em 16 diferentes veículos. Embora os autores afirmem que o modelo para EHT tenha produzido excelente concordância com os dados dos testes subjetivos (tanto para condições de inverno quanto de verão), os mesmos autores também dizem que o índice EHT ainda não é aceito totalmente pelas montadoras norte-americanas (para as quais a aplicação do índice se destina).

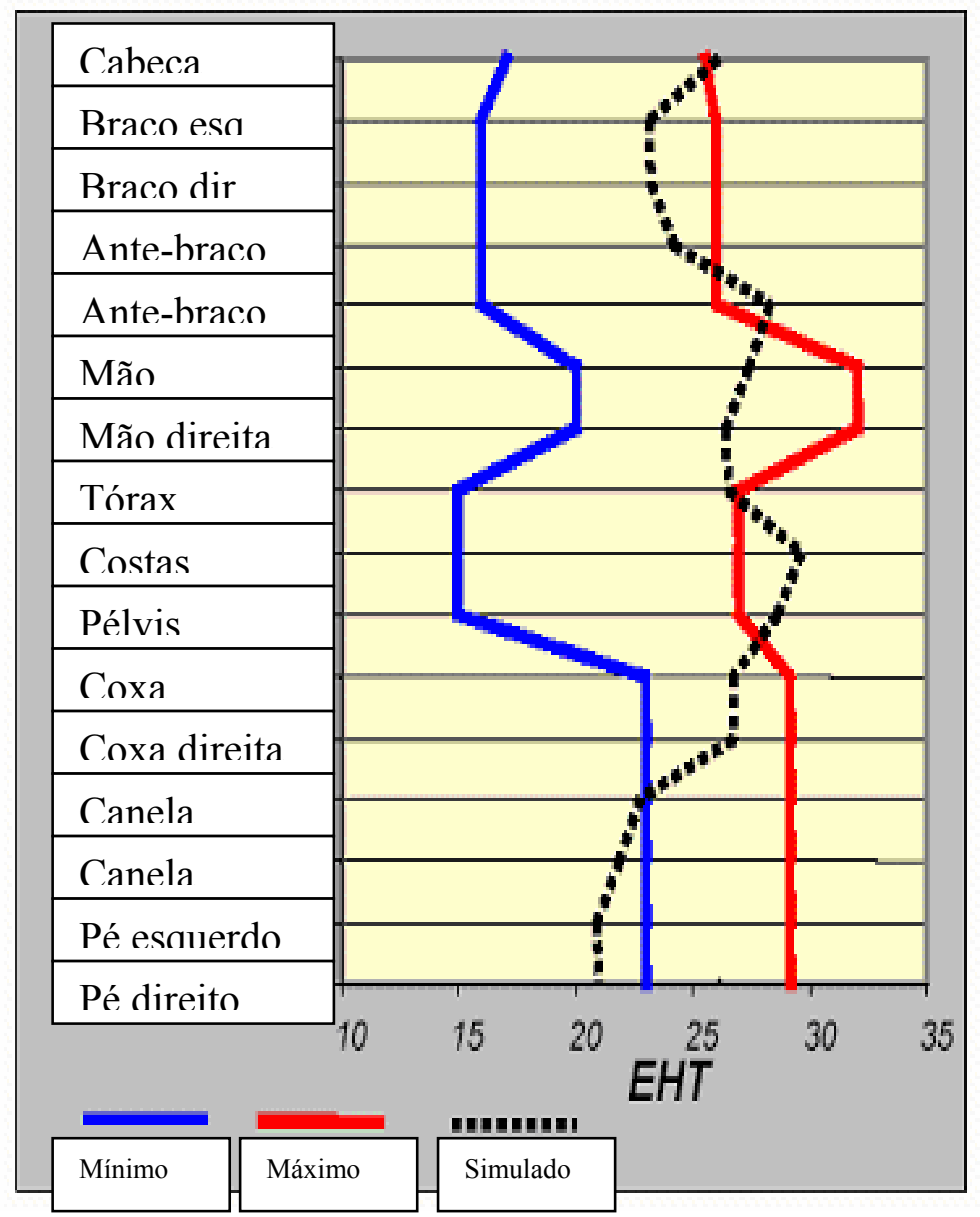

Figura 3.2 - Índices EHT para 16 segmentos do corpo (Han e Huang, 2004) 


\subsection{2 - Avaliação de conforto térmico pela temperatura da pele.}

Alguns pesquisadores têm associado o controle das condições de conforto térmico com a temperatura da pele (uma das condições de conforto térmico de Fanger). Wei e Dage (1995) apresentaram um controlador automático para aplicação em veículos automotivos baseado na leitura da temperatura da pele dos ocupantes através de um sensor infravermelho (bastante utilizado em empresas montadoras de automóveis). Os resultados experimentais mostraram que a resposta do sistema é mais rápida ao incluir no controlador a informação da temperatura da pele do que simplesmente controlar a temperatura do ar. Os resultados obtidos também mostraram correlação entre a temperatura medida na pele com o voto relativo à sensação térmica dos ocupantes.

Furuse e Komoriya (1997) realizaram experimento simulando a cabine de um automóvel e apresentaram um modelo de redes neurais para calcular a sensação de conforto e a sensação térmica total e parcial. O modelo de redes neurais apresentado usa informações da temperatura da pele medidas em 15 pontos diferentes do corpo. A limitação do estudo é que não foram consideradas a radiação solar e umidades do ar elevadas.

\subsection{3 - Avaliação de conforto térmico em regime transitório}

Brown e Jones (1997) desenvolveram um modelo de conforto térmico para regime transitório e realizaram experimentos em veículos para demonstrar a correlação do modelo com o voto de indivíduos submetidos a diversas condições de transientes térmicos durante 45 minutos (típicos de aquecimento no inverno e de resfriamento no verão). O modelo foi alimentado com informações coletadas por diversos sensores de 
temperatura, umidade relativa e velocidade do ar, instalados em um painel de madeira chamado de stickman (Figura 3.3) colocado nos assentos dianteiros. Os resultados mostraram que o modelo apresenta boa correlação com o voto médio dos indivíduos durante os 10 a 15 minutos iniciais, porém tende a divergir do voto subjetivo após este intervalo.

Hosni et al (2003a; 2003b) fizeram alterações no modelo de Brown e Jones para estudar o conforto térmico sob condições fortemente transientes. Foram simuladas condições de inverno e verão em câmara climatizada. A câmara foi provida de lâmpadas para simular uma carga solar de $1000 \mathrm{~W} / \mathrm{m}^{2}$ (condição de verão). Dispositivos dotados de globos para medição da temperatura radiante, temperatura, umidade e velocidade do ar foram utilizados para coletar dados nos ensaios. Paralelamente, foram realizados ensaios nas mesmas condições com pessoas (avaliação subjetiva) Com os dados coletados foi desenvolvido um modelo térmico e os resultados foram comparados com os votos subjetivos para verificar a sua validade. 


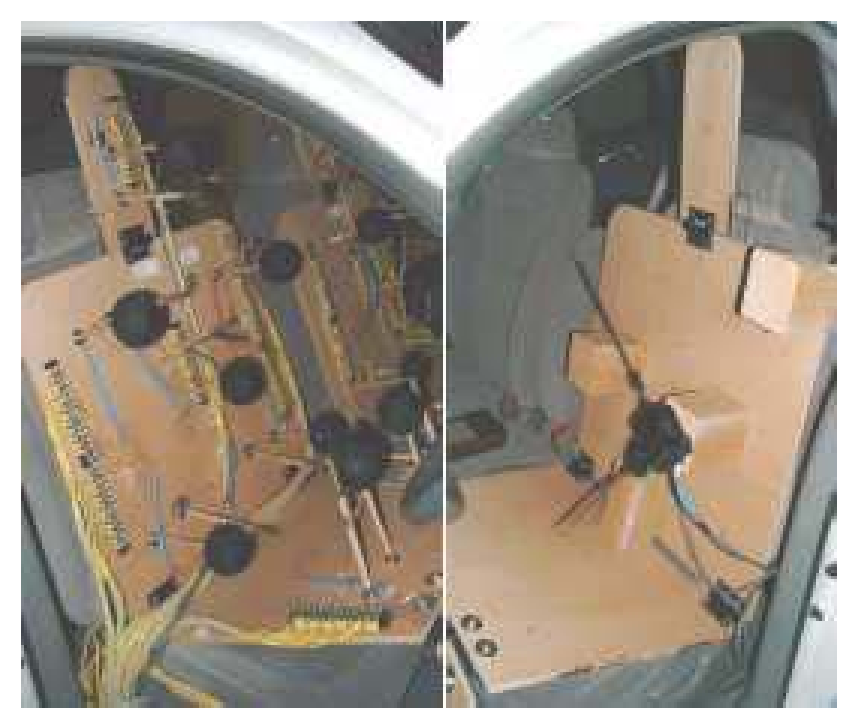

Figura 3.3 Stickman e instrumentação utilizada.

Verifica-se que não existe um número significativo de estudos com ensaios envolvendo a participação de pessoas (ensaios subjetivos) em automóveis. Isto ocorre devido ao alto custo envolvido, da necessidade de protótipos representativos e de câmaras climatizadas para a realização dos ensaios.

Uma tendência é a utilização de manequins virtuais (manequins numéricos) e simulação das trocas de calor utilizando CFD (computacional fluid dynamics), que permite redução do número de testes a um número mínimo, somente para validação da modelagem das trocas de calor e do processo de simulação numérica realizados (Ambs, 2002; Nilsson, 2004). 


\section{CAPÍTULO 4 \\ AVALIAÇÃO DE CONFORTO TÉRMICO \\ EM AUTOMÓVEIS UTILIZANDO MANEQUINS}

Conforme visto no Capítulo 3, em ambientes não homogêneos como os que ocorrem em automóveis, com assimetrias de temperatura, velocidade do ar e de temperaturas radiantes (mesmo em condições de regime permanente), há a necessidade de utilização de métodos específicos para a avaliação das condições de conforto térmico. Uma das formas de se fazer isto é com a utilização de manequins.

\section{1 - Manequins térmicos}

Segundo Gameiro da Silva (2002) o manequim térmico seria o único instrumento capaz de avaliar simultaneamente os efeitos da temperatura do ar local, trocas de calor por radiação do corpo, velocidades do ar e a radiação solar em um veículo (Figura 4.1). Todos estes fenômenos estão presentes dentro de um ambiente pequeno como a cabine de um veículo e tem uma distribuição bastante irregular. $\mathrm{O}$ bloqueio causado pelo corpo, o isolamento dos bancos e as trocas de calor do corpo contribuem para a irregularidade de distribuição dos fenômenos mencionados.

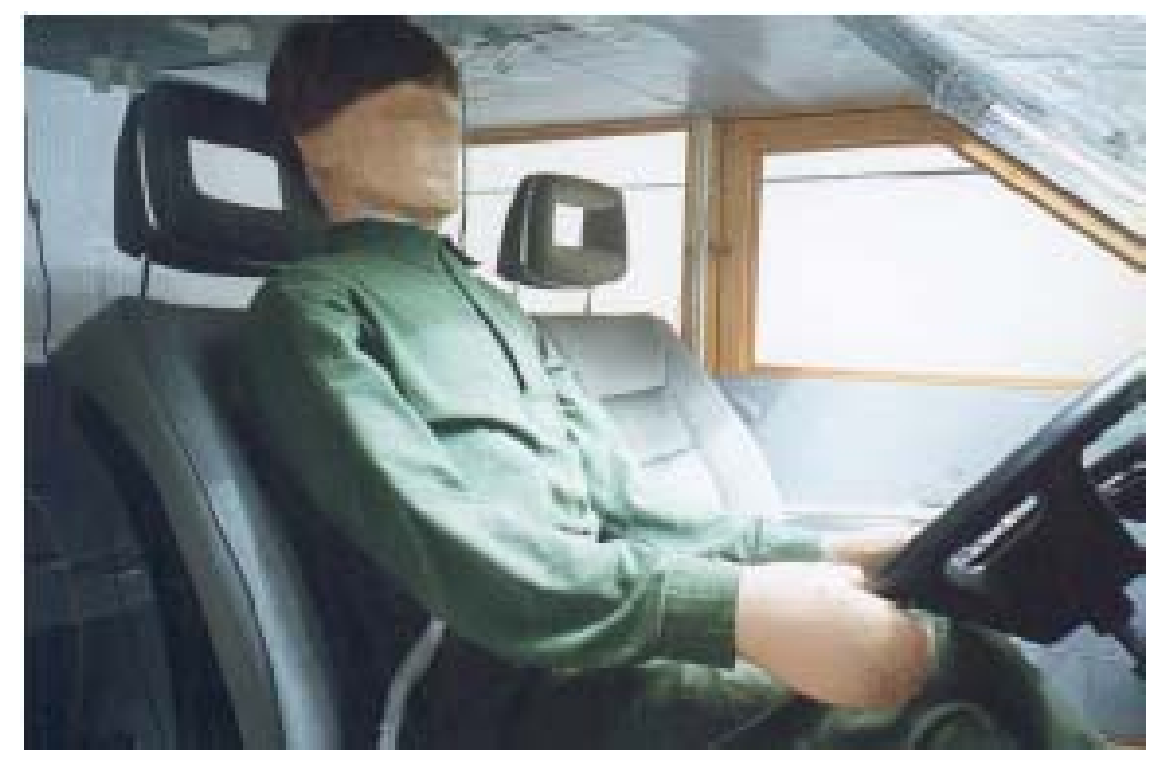

Figura 4.1 Manequim térmico instalado em ambiente simulando uma cabine de automóvel (Nilsson, 2004). 
Nilsson (2004) apresenta um estudo detalhado da utilização de manequins térmicos. Um manequim térmico deve ter algumas características para poder ser usado em avaliação de conforto térmico no interior de veículos. Este deve ter o tamanho e o formato de um corpo humano, ser capaz de ser colocado na posição sentada, ser capaz de ser vestido com roupas e permitir a determinação da influência dos parâmetros físicos relevantes ao conforto térmico ao longo de todo o corpo e com a possibilidade de dividir este corpo em partes ou zonas.

Os manequins atualmente utilizados são divididos em 16 zonas ou mais, até um limite de 32 zonas, independentemente controladas. Para reduzir custos e peso são utilizados materiais como alumínio e plástico. Os controles de regulação dos manequins mais modernos são do tipo digital, mas ainda existem muitos manequins com controles de regulação analógicos (Nilsson, 2004).

Uma completa compreensão da troca de calor do corpo humano requer o conhecimento das perdas de calor do corpo por convecção, condução, radiação e, em alguns casos, perda de calor do corpo por evaporação do suor. Por este motivo, muitos manequins que simulam a sudorese humana estão em desenvolvimento (Nilsson, 2004).

Um manequim térmico com formato humano mede a perda de calor por convecção, condução e radiação de toda a superfície do corpo e em todas as direções. Somando as perdas de calor das áreas das zonas em que o manequim térmico está dividido se determina a perda de calor do corpo inteiro. Um manequim térmico determina a perda de calor de uma maneira relevante, confiável e com acurácia. Este método é rápido, facilmente padronizado e reproduzível (Nilsson, 2004).

Um manequim térmico típico, que não simula sudoreses, é construído com estrutura em alumínio revestida por espuma plástica. Cada zona aquecida independentemente é coberta por resistências elétricas que depois são cobertas por uma resina plástica. Na superfície do manequim são montados sensores de temperatura. Cada uma destas zonas é regulada para uma temperatura constante, por exemplo $24,0^{\circ} \mathrm{C}$, e a potência requerida para manter esta temperatura é indicada pelo sistema de regulação do manequim. Durante estados de equilíbrio esta potência usada para manter o manequim à temperatura constante é igual à potência perdida pelo manequim, ou seja, igual à perda de calor sensível do manequim. A determinação desta perda de calor sensível leva em consideração fatores como temperatura do ar, velocidade do ar, radiação e isolamento das vestimentas utilizadas no manequim. 
O manequim requer um determinado tempo para responder a uma alteração no equilíbrio de troca de calor. Dependendo da construção do manequim e do sistema de regulação utilizado, este tempo pode variar entre 20 e 30 minutos.

Uma vez que os manequins térmicos atuais só permitem determinar a perda de calor sensível, em condições ambientais onde o ser humano começar a suar para perder calor por evaporação do suor haverá uma subestimação do calor total perdido. Entretanto, para pesquisas de conforto térmico realizadas próximo da zona de neutralidade térmica em atividades leves, onde a perda de calor por evaporação representa uma parte mínima da perda de calor total, não haverá um desvio muito grande se for utilizado um manequim térmico que não seja capaz de reproduzir a sudorese humana (Nilsson, 2004).

Antes de ser utilizado, um manequim precisa ser calibrado em um ambiente térmico padrão. O manequim deve ser calibrado com as mesmas vestimentas e na mesma posição que será usado para avaliar o ambiente térmico em estudo. As vestimentas afetam o coeficiente de transferência de calor sensível e, portanto, devem ser escolhidas adequadamente para a situação climática a ser avaliada e devem ser mantidas durante todo o processo de avaliação. Após a calibração o manequim é colocado no local a ser avaliado, o fluxo de calor em $\mathrm{W} / \mathrm{m}^{2}$ das diferentes zonas do manequim são medidos e controlados pelo sistema de regulação do manequim. Os dados do sistema de regulação são levados em consideração somente quando o manequim entra em equilíbrio térmico devido ao atraso de resposta as condições transientes dos manequins.

As desvantagens de se utilizar manequins térmicos são o custo destes equipamentos, a dificuldade de manuseá-los e são equipamentos delicados e difíceis de manter. Além disso, os manequins que não são capazes de simular a sudorese humana, quando expostos a ambientes muito quentes, não serão capazes de avaliar as condições de conforto térmico de tal ambiente, pois o manequim não irá perder calor para o ambiente e sim ganhar calor do ambiente e o sistema de regulação destes manequins não é capaz de medir corretamente este ganho de calor. Além disso, a demora em responder às alterações de condições no ambiente limita a utilização do manequim apenas às condições de equilíbrio térmico, não sendo possível avaliar as condições transientes (Hosni et al., 2003a; 2003b).

Atualmente existe um grande número de manequins térmicos sendo construídos e utilizados no mundo inteiro, mas a falta de uma norma padronizando 
sua construção dificulta a comparação entre resultados obtidos por diferentes manequins em diferentes ambientes (Nilsson, 2004).

\section{2 - Manequins com sensores aquecidos}

Uma outra forma de se avaliar condições de conforto térmico em automóveis é com a utilização de manequins com sensores aquecidos, previsto na norma ISO 14505-2 (2004). Neste caso o manequim não é aquecido como no caso do manequim térmico. Em vez de se fazer a avaliação das trocas de calor em diversos segmentos do corpo aquecido, são colocados sensores aquecidos nestes segmentos do corpo (normalmente 16 ou 32 segmentos). No presente estudo será utilizado um manequim com sensores aquecidos, descrito no Capítulo 5.

Semelhante ao que é feito com manequins aquecidos, antes de ser utilizado, o manequim com sensores aquecidos também precisa ser calibrado em um ambiente térmico padrão. Detalhes deste procedimento e da avaliação das temperaturas equivalentes serão descritos a seguir.

4.2.1 - Determinação de temperaturas equivalentes utilizando manequim (ISO, 14505-2)

A norma ISO 14505-2 (2004) trata da determinação de temperaturas equivalentes, $\mathrm{t}_{\mathrm{eq}}$, na avaliação de conforto térmico em automóveis. Esta norma prevê a utilização dos métodos de medição da temperatura equivalente usando manequins térmicos e também sensores aquecidos.

A determinação de $t_{\text {eq }}$ é baseada na transferência de calor por convecção e radiação para manequins com vestimentas padrão para cada tipo de ensaio: condições de inverno (aquecimento) e condições de verão (resfriamento). Para condições de verão a norma prevê uma vestimenta com 0,6 clo e para a de inverno com 1,0 clo.

A transferência de calor por condução é assumida como sendo pequena e a perda de calor por evaporação de suor não é considerada já que em condições normais de uso do veículo (atividade leve) a quantidade de suor é pequena. Assim, as trocas de 
calor se limitam as trocas de calor por radiação $\mathrm{R}$ e por convecção $\mathrm{C}$, dadas pelas eqs. 4.1 e 4.2 :

$$
\begin{array}{lr}
R=h_{r}\left(t_{s}-\bar{t}_{r}\right) & {\left[\mathrm{W} / \mathrm{m}^{2}\right]} \\
C=h_{c}\left(t_{s}-t_{a r}\right) & {\left[\mathrm{W} / \mathrm{m}^{2}\right]}
\end{array}
$$

onde:

$\mathrm{C}=$ troca de calor por condução

$\left[\mathrm{W} / \mathrm{m}^{2}\right]$

$\mathrm{R}=$ troca de calor por radiação

$\left[\mathrm{W} / \mathrm{m}^{2}\right]$

$\mathrm{h}_{\mathrm{r}}=$ coeficiente de transferência de calor por radiação

$\left[\mathrm{W} / \mathrm{m}^{2 \mathrm{o}} \mathrm{C}\right]$

$h_{c}=$ coeficiente de transferência de calor por condução

$\left[\mathrm{W} / \mathrm{m}^{2 \mathrm{o}} \mathrm{C}\right]$

$\mathrm{t}_{\mathrm{s}}=$ temperatura da superfície

$\bar{t}_{r}=$ temperatura radiante média

$\mathrm{t}_{\mathrm{ar}}=$ temperatura do ar ambiente

Estas trocas de calor por convecção e radiação ocorrem simultaneamente. Assim, a temperatura equivalente, $\mathrm{t}_{\mathrm{eq}}$, definida pela norma é função das trocas de calor por convecção e radiação e é dada por:

$$
t_{e q}=t_{s}-\frac{Q}{h}
$$

onde: 
$\mathrm{Q}=\mathrm{R}+\mathrm{C}=$ troca de calor por radiação e convecção

$\mathrm{t}_{\mathrm{eq}}=$ temperatura do ambiente padrão

$\mathrm{t}_{\mathrm{s}}=$ temperatura da superfície

$\left[{ }^{\circ} \mathrm{C}\right]$

$\mathrm{h}=$ coeficiente de transferência de calor combinado, convecção e radiação $\left[\mathrm{W} / \mathrm{m}^{2 \mathrm{o}} \mathrm{C}\right]$

\subsubsection{Procedimento de calibração do manequim}

A norma ISO 14505-2 (2004) também apresenta o procedimento de calibração de manequins em um ambiente térmico padrão. $\mathrm{O}$ ambiente padrão é um ambiente homogêneo com temperatura de bulbo seco de $24^{\circ} \mathrm{C}, \bar{t}_{r}=\mathrm{t}_{a r}$, e com velocidade do ar $\mathrm{V}<0,1 \mathrm{~m} / \mathrm{s}$. O manequim deve ser calibrado com as mesmas vestimentas e na mesma posição que será usado para avaliar o ambiente térmico em estudo.

No procedimento de ensaio de calibração considerando sensores aquecidos, todos os segmentos do corpo deverão dissipar a mesma quantidade de calor, Q. Na norma são padronizados fluxos de calor de $70 \mathrm{~W} / \mathrm{m}^{2}$ (1,2 met) e $90 \mathrm{~W} / \mathrm{m}^{2}$ (1,6 met).

Uma vez satisfeitas estas condições em ensaio realizado em câmara climatizada e obtidas condições de regime permanente nas trocas de calor do manequim com o ambiente, são realizadas leituras de temperaturas superficiais, $\mathrm{t}_{\mathrm{s}}$, e de fluxo de calor para cada segmento do corpo e calculados valores de coeficientes de troca de calor, $\mathrm{h}_{\text {cal }}$, que são os coeficientes de troca de calor calibrados, dados pela equação: 


$$
h_{c a l}=\frac{Q}{t_{s}-t_{e q}} \quad\left[\mathrm{~W} / \mathrm{m}^{2}{ }^{\circ} \mathrm{C}\right]
$$

Os valores de coeficientes de transferência de calor calibrados, $h c a l$, serão os valores de coeficiente de troca de calor, $h$, da Equação 4.3 no cálculo das temperaturas equivalentes no ambiente real.

Uma vez calibrado o manequim para a posição e vestimenta do ensaio real, o método de avaliação consiste em posicionar o manequim no ambiente real como, por exemplo, na Figura 4.1, e medir os fluxos de calor e as temperaturas de superfície de cada segmento. Por meio da Equação 4.3 é possível determinar a teq para cada segmento ou para todo o corpo utilizando os valores de $\mathrm{h}_{\text {cal }}$ calibrados e os novos valores de $\mathrm{Q}$ e $\mathrm{t}_{\mathrm{s}}$.

A temperatura equivalente assim determinada é um indicador do nível de afastamento entre a temperatura do ambiente e a temperatura correspondente a uma sensação térmica de neutralidade.

A norma ISO 14505-2 (2004) apresenta diagramas para avaliação da $t_{\text {eq }}$ em função da sensação térmica, para manequim com 16 segmentos (Fig. 4.2). Os diagramas apresentados se referem a uma condição de verão, com o sistema de climatização operando na condição de resfriamento e pessoas usando roupas leves com clo igual a 0,6 (Fig. 4.3) e a uma condição de inverno, com o sistema operando na condição de aquecimento e pessoas usando roupas pesadas com clo igual a 1,0 (Fig. 4.4). 

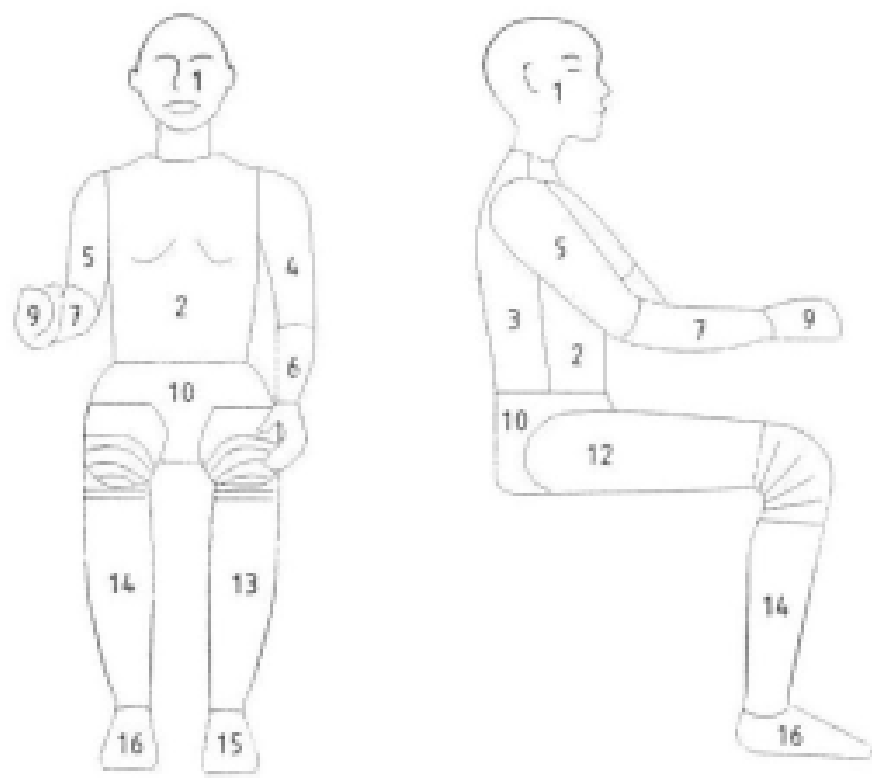

Figura 4.2 Manequim com 16 segmentos (ISO 14505-2, 2004)

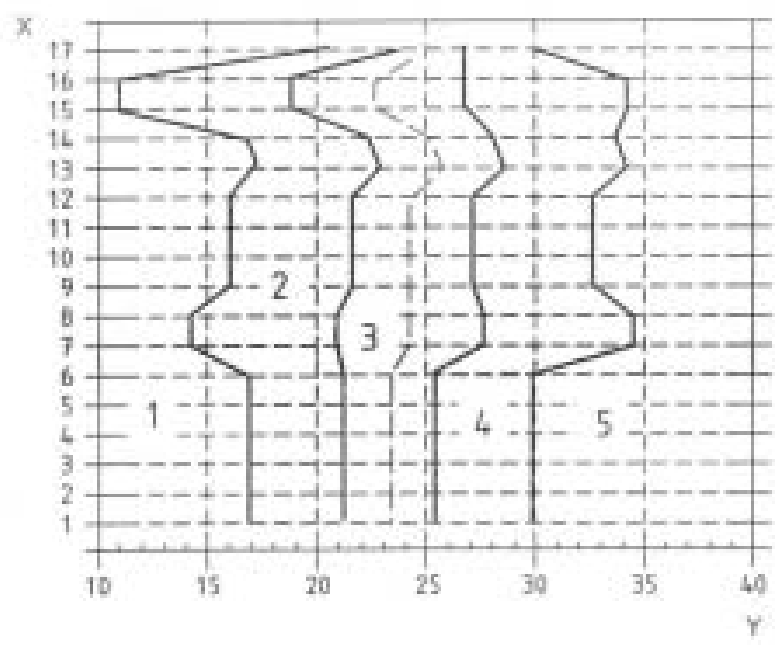

Figura 4.3 Diagrama para avaliação de $t_{\mathrm{eq}}$ em função da sensação térmica: condição de verão, resfriamento (ISO 14505-2, 2004). 


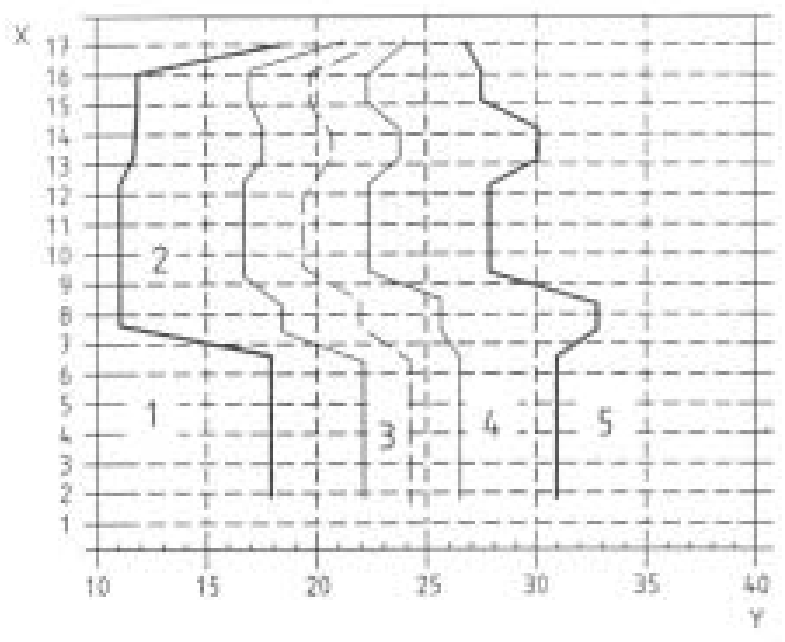

Figura 4.4 Diagrama para avaliação de $t_{\mathrm{eq}}$ em função da sensação térmica: condição de inverno, aquecimento (ISO 14505-2, 2004).

Os valores de Y nas Figuras 4.3 e 4.4 correspondem às temperaturas equivalentes, $\mathrm{t}_{\mathrm{eq}}$, e os valores de $\mathrm{X}$ aos segmentos do corpo (manequim). $\mathrm{O}$ segmento 17 corresponde à $t_{\text {eq }}$ para o corpo como um todo. Os números 1 a 5 representam as faixas de sensação térmica conforme apresentado na Tabela 4.1 .

Tabela 4.1 Escala de sensação térmica da norma ISO 14502-2 (2004).

\begin{tabular}{|c|c|c|c|c|}
\hline \multicolumn{5}{|c|}{ Escala de sensação térmica } \\
\hline $\mathbf{1}$ & $\mathbf{2}$ & $\mathbf{3}$ & $\mathbf{4}$ & $\mathbf{5}$ \\
\hline Muito frio & Frio/confortável & Confortável & Quente/confortável & Muito quente \\
\hline
\end{tabular}




\section{CAPÍTULO 5 \\ PROCEDIMENTO DE ENSAIO \\ UTILIZANDO MANEQUIM}

\subsection{Descrição do manequim utilizado nos ensaios}

Para a realização dos ensaios foi utilizado um manequim (Figura 5.1), denominado Sim $\mathrm{Ter}^{6}$, de 16 segmentos, com sensores aquecidos com potência de aquecimento regulável analogicamente $\left(40 \mathrm{a} 120 \mathrm{~W} / \mathrm{m}^{2}\right)$ dispostos um na testa, dois nos braços, dois nos ante-braços, dois nas mãos, dois nas coxas, dois nas canelas, dois nos pés, um no peito, um nas nádegas e um nas costas (Figura 5.1). Cada região (sensor aquecido) é dotado também de um sensor para leitura de temperatura superficial.
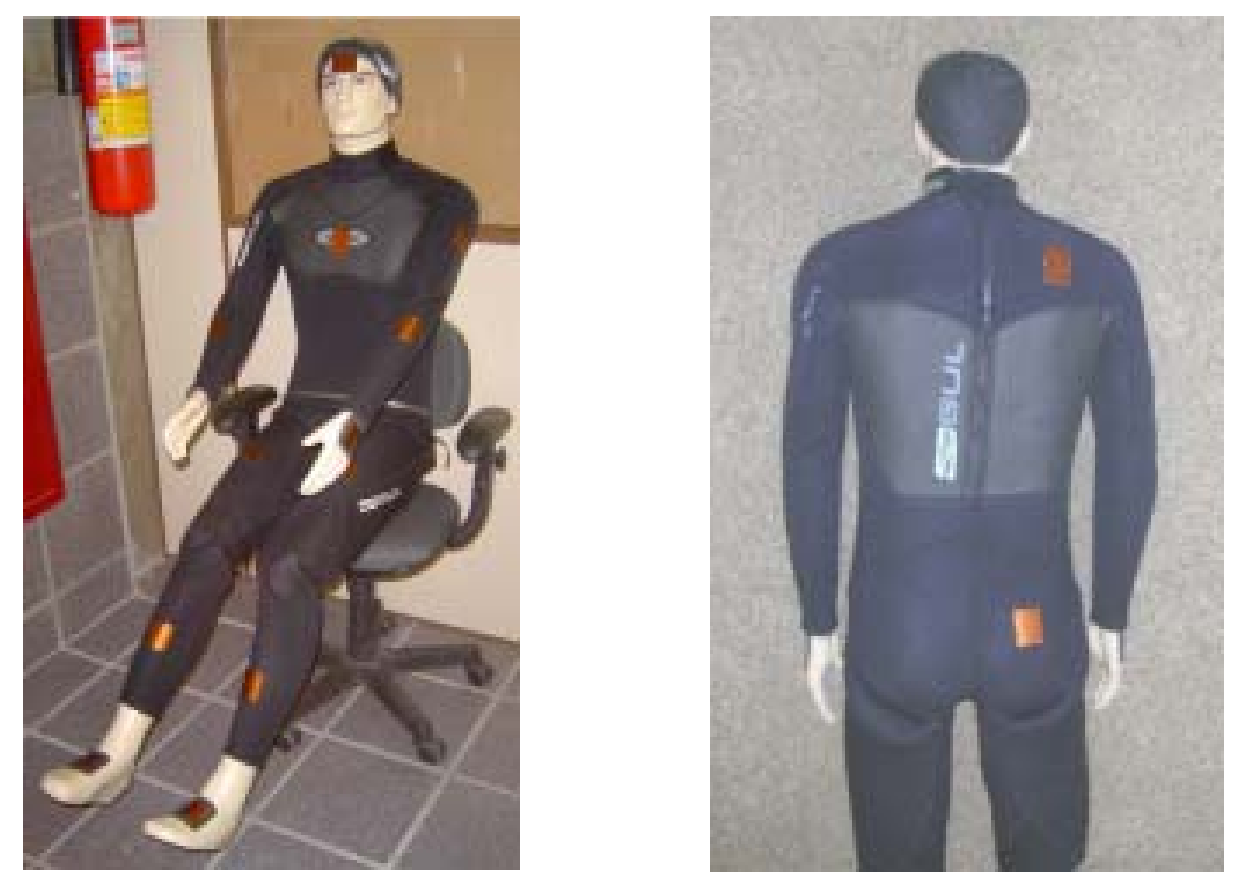

Figura 5.1 Manequim com sensores aquecidos utilizado nos ensaios.

\footnotetext{
${ }^{6}$ Projetado e construído no Laboratório de Meios Porosos e Propriedades Termofísicas do Departamento de Engenharia Mecânica da Universidade Federal de Santa Catarina, Florianópolis - SC.
} 
O sistema de controle é composto por dois módulos que são conectados com o manequim e sensores adicionais. O manequim é conectado a um módulo B de controle de potência (Fig. 5.2), no qual ainda podem ser conectados 6 termoanemômetros omnidirecionais, 1 termômetro de globo e 1 sensor de temperatura.

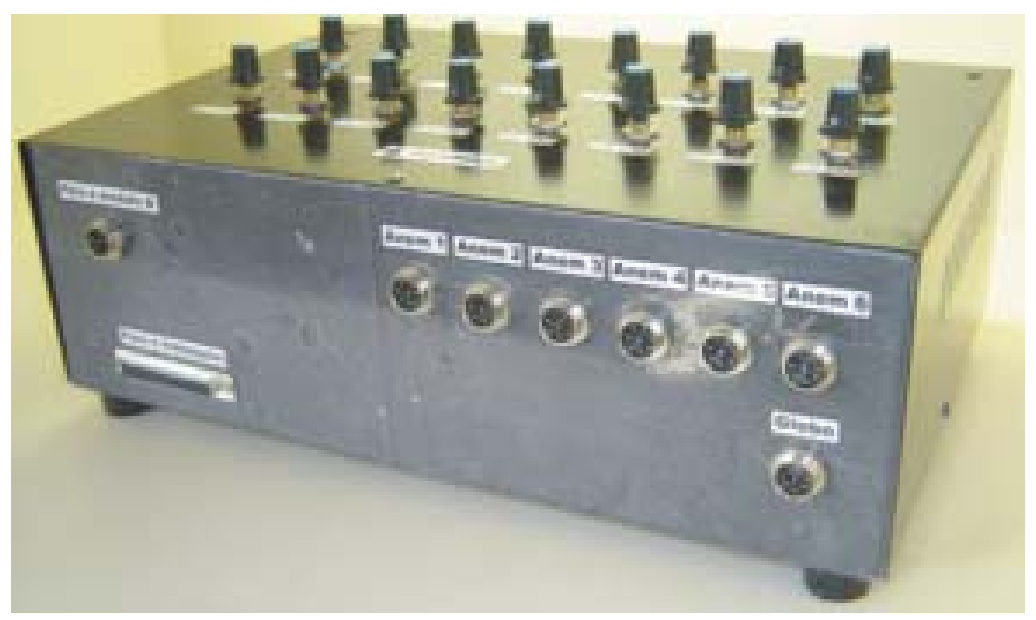

Figura 5.2 Módulo B de controle de potência e conexão de sensores para levantamento de dados ambientais.

O Módulo B é conectado a um módulo A de aquisição (Figura 5.3.), que por sua vez é conectado ao micro computador através da porta serial. O software de aquisição (SimTer.exe) roda em sistema Windows, onde podem ser visualizados os valores de calor dissipado em cada segmento e as respectivas temperaturas superficiais, bem como a velocidade, temperatura do ar e a temperatura de globo do ambiente analisado.

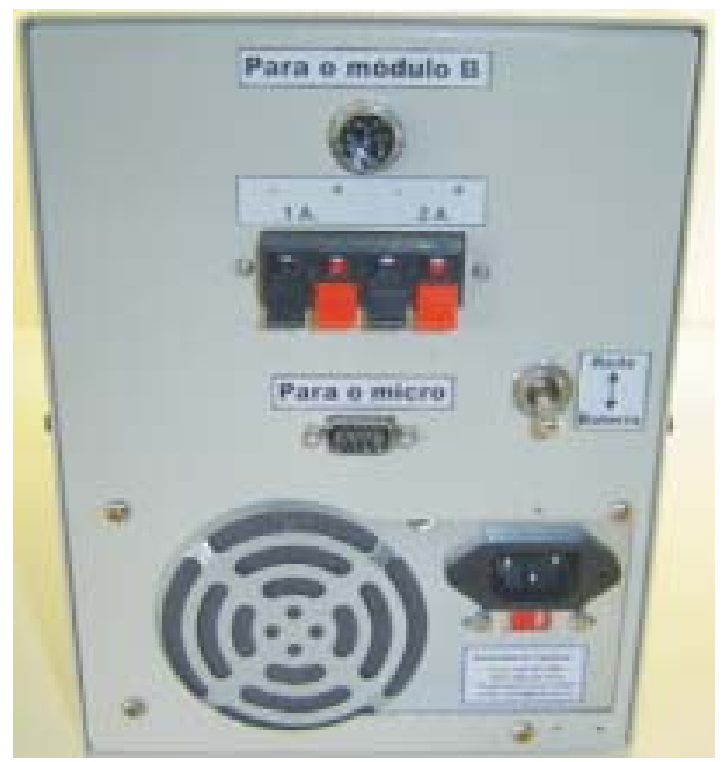


Figura 5.3 Módulo A de aquisição de sinais

Os dados podem ser registrados no disco rígido em intervalo definido pelo usuário, sendo que os valores registrados representam as médias do período. $\mathrm{O}$ ambiente do software de aquisição de dados é apresentado na Figura 5.4.

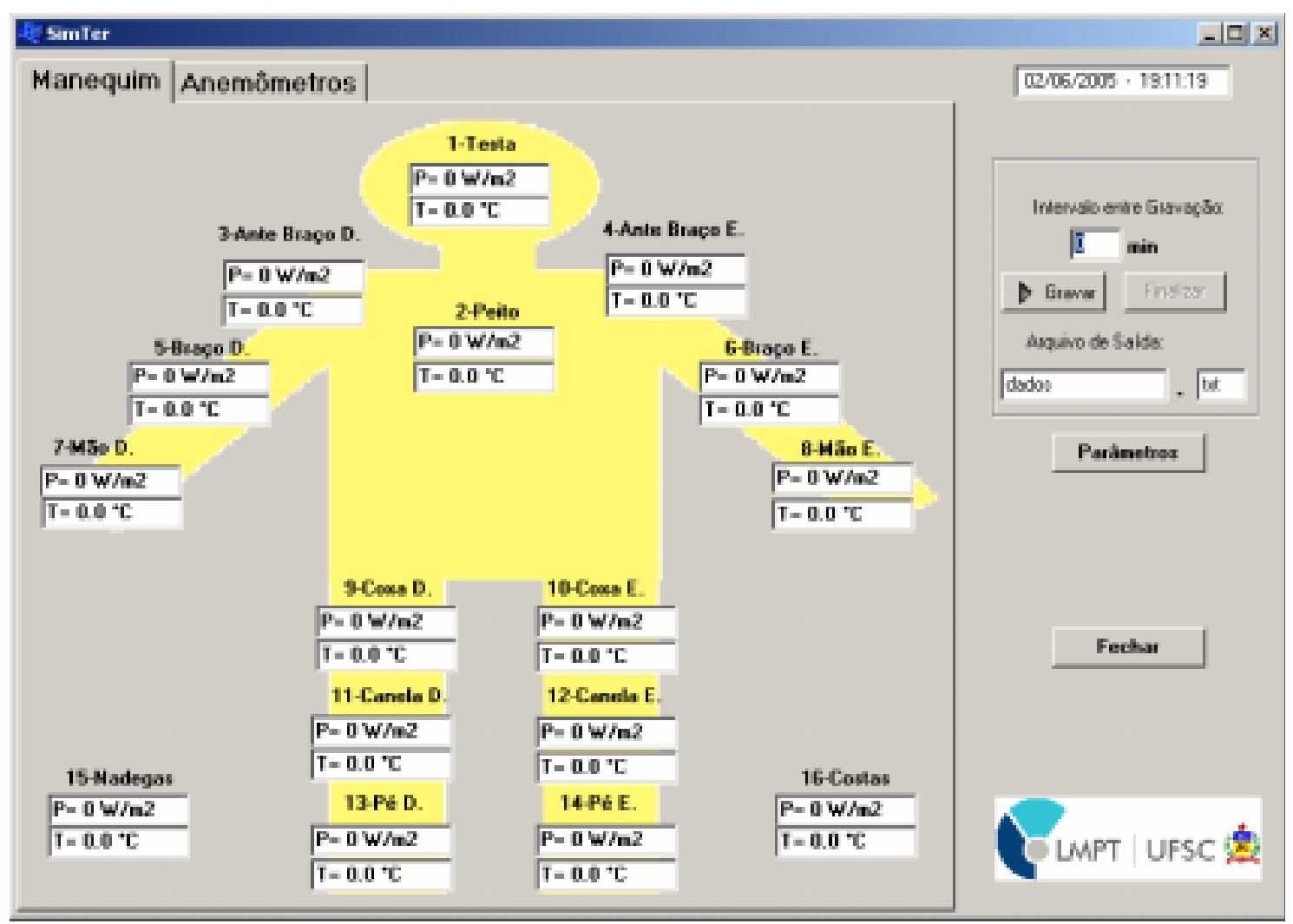

Figura 5.4 Software de aquisição do sistema SimTer

As faixas de medição e precisão nas medições de temperaturas, velocidades e potências são apresentadas na Tabela 5.1 .

Tabela 5.1 Características dos instrumentos de medição do sistema SimTer.

\begin{tabular}{|l|c|c|}
\hline \multicolumn{1}{|c|}{ Variáveis } & Faixa de medição & Precisão \\
\hline Temperatura superficial & $0-50{ }^{0} \mathrm{C}$ & $\pm 0,3{ }^{\circ} \mathrm{C}$ \\
\hline Temperatura do ar & $0-50{ }^{\circ} \mathrm{C}$ & $\pm 0,3{ }^{\circ} \mathrm{C}$ \\
\hline Velocidade do ar & $0-3 \mathrm{~m} / \mathrm{s}$ & $\pm 0,04+3 \% \mathrm{~m} / \mathrm{s}$ \\
\hline Potência & $40-120 \mathrm{~W} / \mathrm{m} 2$ & $3 \%$ \\
\hline
\end{tabular}

\subsection{Calibração do manequim}


Inicialmente foi feita calibração do manequim SimTer de acordo com procedimento previsto na norma ISO 14505-2 (2004), apresentado no Capítulo 4. A calibração foi realizada em ambiente climatizado com condições controladas utilizado na avaliação de condições de conforto em ambientes de escritórios com insuflamento pelo piso (Leite, 2003). O manequim foi colocado no ambiente climatizado em posição similar àquela em que seria posteriormente colocado no veículo para teste, conforme apresenta na Figura 5.5.

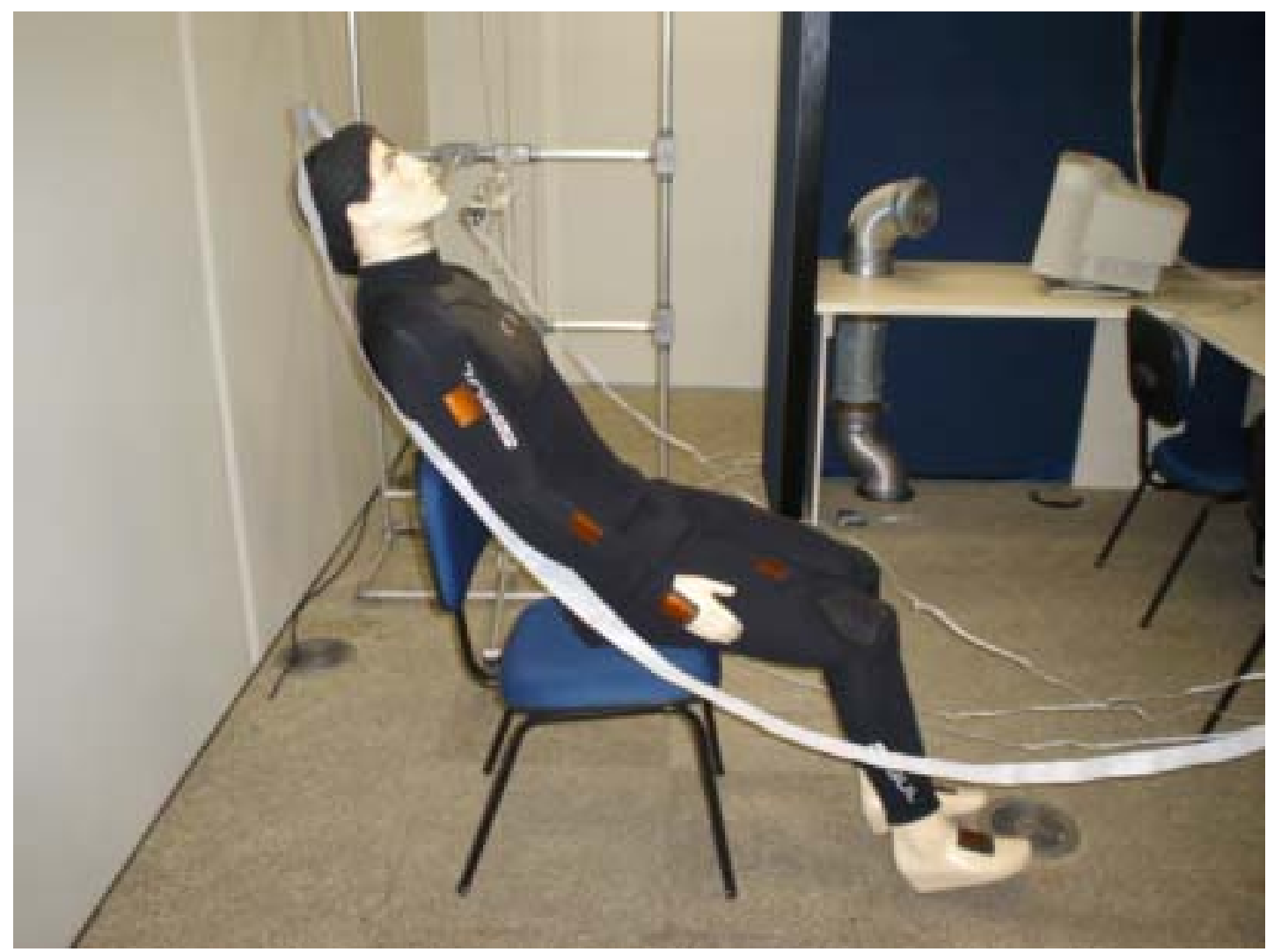

Figura 5.5 Posicionamento do manequim na câmara para calibração

A temperatura da câmara foi monitorada durante os ensaios, bem como a velocidade, que permaneceram nos valores previstos na norma: em torno de $24{ }^{\circ} \mathrm{C}$, com $\mathrm{V}<0,1 \mathrm{~m} / \mathrm{s}$ (em torno de $0,03 \mathrm{~m} / \mathrm{s}$ ).

Foram realizadas duas calibrações. Uma calibração foi executada com o manequim trajando vestimenta com 0,6 clo, para condições de verão, e a outra calibração com vestimenta de 1,0 clo, para condições de inverno. 
Uma vez atingidas condições de regime permanente (tanto do ambiente, quanto da troca de calor no manequim), foram realizadas as medições de temperatura superficial $\mathrm{t}_{s} \mathrm{e}$ de fluxo de calor em cada segmento do corpo, Q. Depois foram obtidos os valores de coeficientes de troca de calor calibrados, $h_{\text {cal }}$, aplicando a Eq. (4.4) (reapresentada aqui):

$$
h_{c a l}=\frac{Q}{t_{s}-t_{e q}} \quad\left[\mathrm{~W} / \mathrm{m}^{2}{ }^{\circ} \mathrm{C}\right]
$$

Os resultados das calibrações do manequim são apresentados nas tabelas 5.2 e 5.3.

Tabela 5.2 Valores dos coeficientes de troca de calor para cada parte do corpo com vestimenta de 0,6 clo (condição de verão).

\begin{tabular}{|l|c|c|c|c|}
\hline & $\mathbf{Q}(\mathbf{W} / \mathbf{m} \mathbf{2})$ & $\left.\mathbf{t}_{\mathbf{s}} \mathbf{(}{ }^{\mathbf{0}} \mathbf{C}\right)$ & $\mathbf{t}_{\text {ar }}\left({ }^{\mathbf{o}} \mathbf{C}\right)$ & $\mathbf{h}_{\text {cal }}\left(\mathbf{W} / \mathbf{m}^{\mathbf{2}} \mathbf{0}^{\mathbf{0}}\right)$ \\
\hline Corpo todo & 71,4 & 27,4 & 23,9 & 20,4 \\
\hline Face & 70,6 & 27,0 & 23,9 & 23,2 \\
\hline Tórax & 71,1 & 29,9 & 23,9 & 11,8 \\
\hline Costas & 70,4 & 27,1 & 23,9 & 22,5 \\
\hline Braço esquerdo & 72,8 & 28,2 & 23,9 & 17,1 \\
\hline Braço direito & 71,1 & 27,7 & 23,9 & 19,0 \\
\hline Ante-braço esquerdo & 72,0 & 27,1 & 23,9 & 22,8 \\
\hline Ante-braço direito & 70,6 & 26,6 & 23,9 & 26,4 \\
\hline Mão esquerda & 70,0 & 26,6 & 23,9 & 25,9 \\
\hline Mão direita & 71,5 & 26,9 & 23,9 & 24,5 \\
\hline Coxa esquerda & 69,9 & 27,1 & 23,9 & 22,3 \\
\hline Coxa direita & 70,8 & 27,4 & 23,9 & 20,2 \\
\hline Canela esquerda & 70,8 & 27,8 & 23,9 & 18,4 \\
\hline Canela direita & 71,4 & 27,4 & 23,9 & 21,6 \\
\hline Pé esquerdo & 69,6 & 27,2 & 23,9 & 21,0 \\
\hline Pé direito & 70,2 & 27,6 & 23,9 & 19,4 \\
\hline Nádegas & 71,0 & 27,6 & 23,9 & 19,3 \\
\hline
\end{tabular}

Tabela 5.3 Valores dos coeficientes de troca de calor para cada parte do corpo com vestimenta de 1,0 clo (condição de inverno).

\begin{tabular}{|l|c|c|c|c|}
\hline & $\mathrm{Q}(\mathbf{W} / \mathbf{m} 2)$ & $\mathbf{t}_{\mathbf{s}}\left({ }^{\mathbf{0}} \mathbf{C}\right)$ & $\mathbf{t}_{\mathbf{a r}}\left({ }^{\mathbf{}} \mathbf{C}\right)$ & $\mathbf{h}_{\text {cal }}\left(\mathbf{W} / \mathbf{m}^{\mathbf{2}}{ }^{\mathbf{0}} \mathbf{C}\right)$ \\
\hline Corpo todo & 70,7 & 27,5 & 23,8 & 19,3 \\
\hline Face & 71,9 & 26,9 & 23,8 & 23,2 \\
\hline Tórax & 71,0 & 29,9 & 23,8 & 11,6 \\
\hline Costas & 70,2 & 27,7 & 23,8 & 17,9 \\
\hline Braço esquerdo & 71,4 & 28,3 & 23,8 & 15,8 \\
\hline
\end{tabular}




\begin{tabular}{|l|l|l|l|l|} 
Braço direito & 71,2 & 27,1 & 23,8 & 22,1 \\
\hline Ante-braço esquerdo & 72,7 & 27,8 & 23,8 & 18,3 \\
\hline Ante-braço direito & 70,2 & 27,7 & 23,8 & 18,3 \\
\hline Mão esquerda & 71,2 & 26,6 & 23,8 & 25,9 \\
\hline Mão direita & 70,3 & 26,7 & 23,8 & 24,5 \\
\hline Coxa esquerda & 70,2 & 26,9 & 23,8 & 22,2 \\
\hline Coxa direita & 70,7 & 27,3 & 23,8 & 20,3 \\
\hline Canela esquerda & 70,7 & 27,5 & 23,8 & 19,0 \\
\hline Canela direita & 70,6 & 27,2 & 23,8 & 21,2 \\
\hline Pé esquerdo & 69,8 & 27,3 & 23,8 & 20,1 \\
\hline Pé direito & 70,0 & 27,4 & 23,8 & 19,5 \\
\hline Nádegas & 70,8 & 27,5 & 23,8 & 19,3 \\
\hline
\end{tabular}

Verifica-se pela análise dos resultados apresentados nas Tabelas 5.2 e 5.3 que houve problemas em se conseguir manter os fluxos de calor constantes em $70 \mathrm{~W} / \mathrm{m}^{2}$, (valor recomendado na norma) em todos os segmentos. Isto é uma deficiência apresentada pelo equipamento relacionado com o controle analógico. Contudo, estas diferenças não influenciam significativamente os resultados finais de temperaturas equivalente levantados (Capítulo 6), com incertezas em torno de $\pm 0,5^{\circ} \mathrm{C}$.

\subsection{Procedimento de ensaio nas avaliações nos automóveis}

Após a calibração do manequim foram realizados três ensaios diurnos para condições de verão com vestimentas de 0,6 clo (resfriamento) e três ensaios noturnos com condições de inverno com vestimentas de 1,0 clo (aquecimento)

Os ensaios foram realizados em três veículos de passeio, modelos standard, de três diferentes montadoras, identificados como Veículos A, B e C. Todos os três veículos são equipados com sistemas de ar condicionado e ar quente sendo que os Veículos A e B possuem sistema de controle de temperatura eletrônico e o Veículo C possui sistema de controle de temperatura manual. Todos os sistemas de controle de temperatura operam através de mistura de ar frio proveniente do sistema de ar condicionado e ar quente proveniente do sistema de aquecimento do veículo. Estas misturas são obtidas por meio das combinações de abertura de válvulas do tipo portinhola. Os sistemas podem ser regulados para frio máximo com ar proveniente apenas do sistema de ar condicionado, quente máximo com ar proveniente apenas do sistema de aquecimento do veículo ou qualquer mistura de ar frio e ar quente entre estes dois pontos. No caso dos veículos com controle manual de temperatura as portinholas, depois de reguladas, permanecem em uma 
posição fixa e no caso do controle eletrônico de temperatura as portinholas são controladas por um módulo eletrônico e um sensor de temperatura interno no veículo para manter a temperatura no interior do veículo constante e dentro da faixa selecionada pelo ocupante do veículo.

Os ensaios foram realizados em três dias consecutivos, um dia para cada veículo, e com condições climáticas praticamente iguais, com dias quentes e noites frias típicas de "veranico de inverno": dias ensolarados e noites estreladas (sem nuvem alguma), ausência de ventos e baixa umidade relativa (em torno de $40 \%$ ).

Cada dia de ensaio foi dividido em duas partes. A primeira parte do ensaio foi realizada durante o dia em condições de verão e o manequim com roupas de 0,6 clo (Fig. 5.6). A segunda parte do ensaio foi realizada durante a noite em condições de inverno e com o manequim com roupas de 1,0 clo (Fig. 5.7).

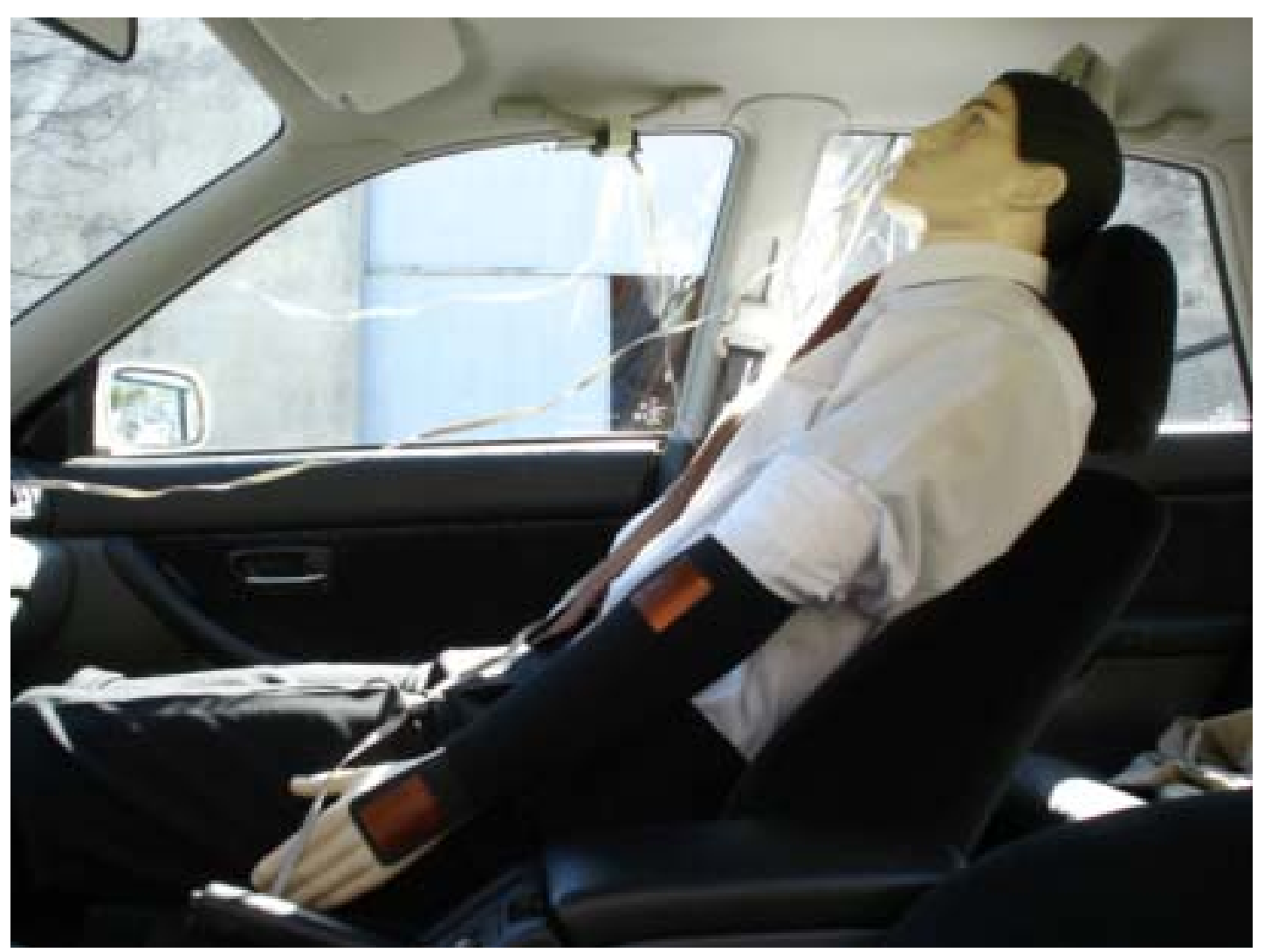

Figura 5.6 Manequim posicionado para ensaio com roupa 0,6 clo (verão) 


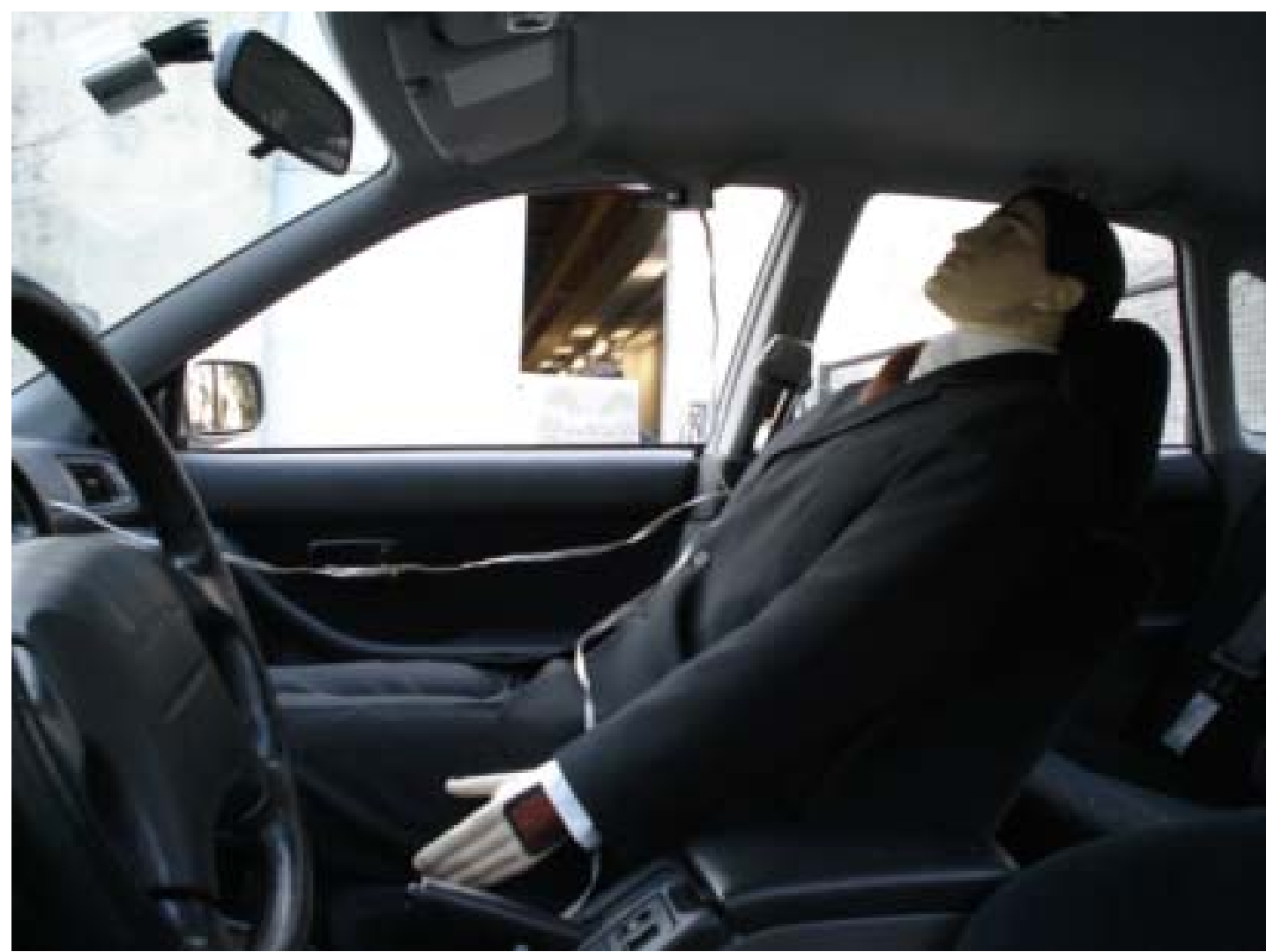

Figura 5.7 Manequim posicionado para ensaio com roupa

\section{1,0 clo.}

Os veículos foram instrumentados com o manequim e com quatro conjuntos de sensores de temperatura e velocidade (para monitorar as temperaturas e velocidades no interior da cabine). O manequim e os termopares foram montados na mesma posição em todos os veículos, a saber, o manequim na posição dianteira lado do passageiro e os termopares na altura da cabeça, tórax, pés e sobre o painel de instrumentos como pode ser visto nas Figuras 5.8 a 5.11. 


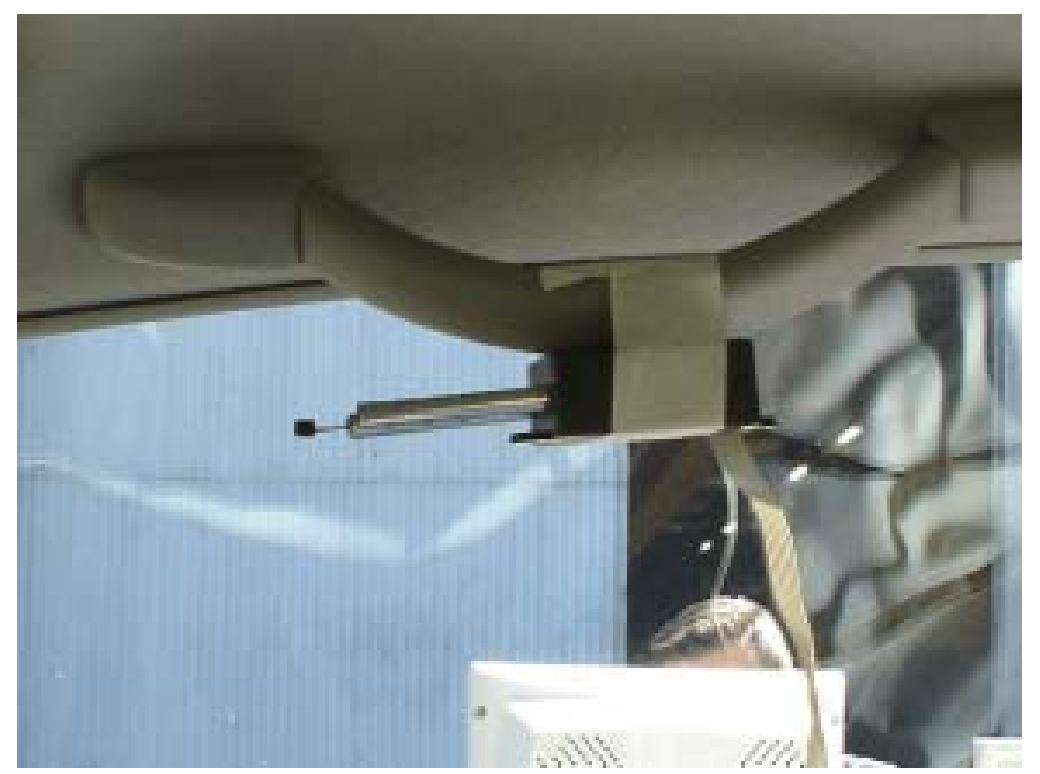

Figura 5.8 Posição do anemômetro e termômetro na altura da cabeça

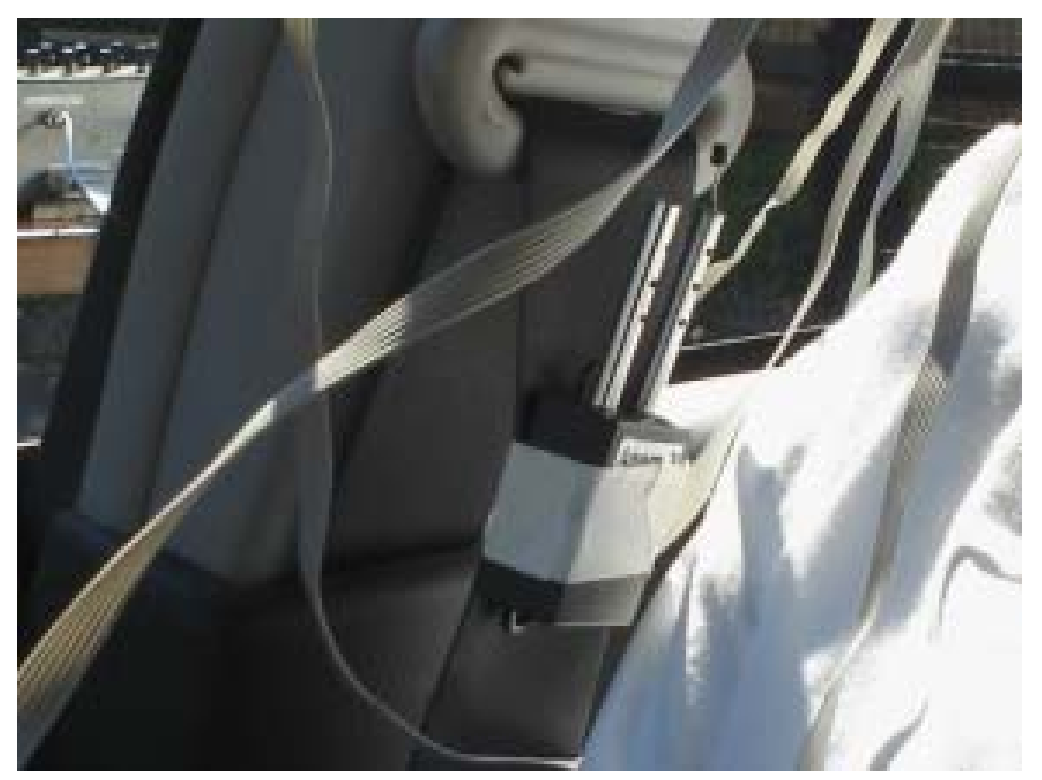

Figura 5.9 Posição do anemômetro e termômetro na altura do tórax 


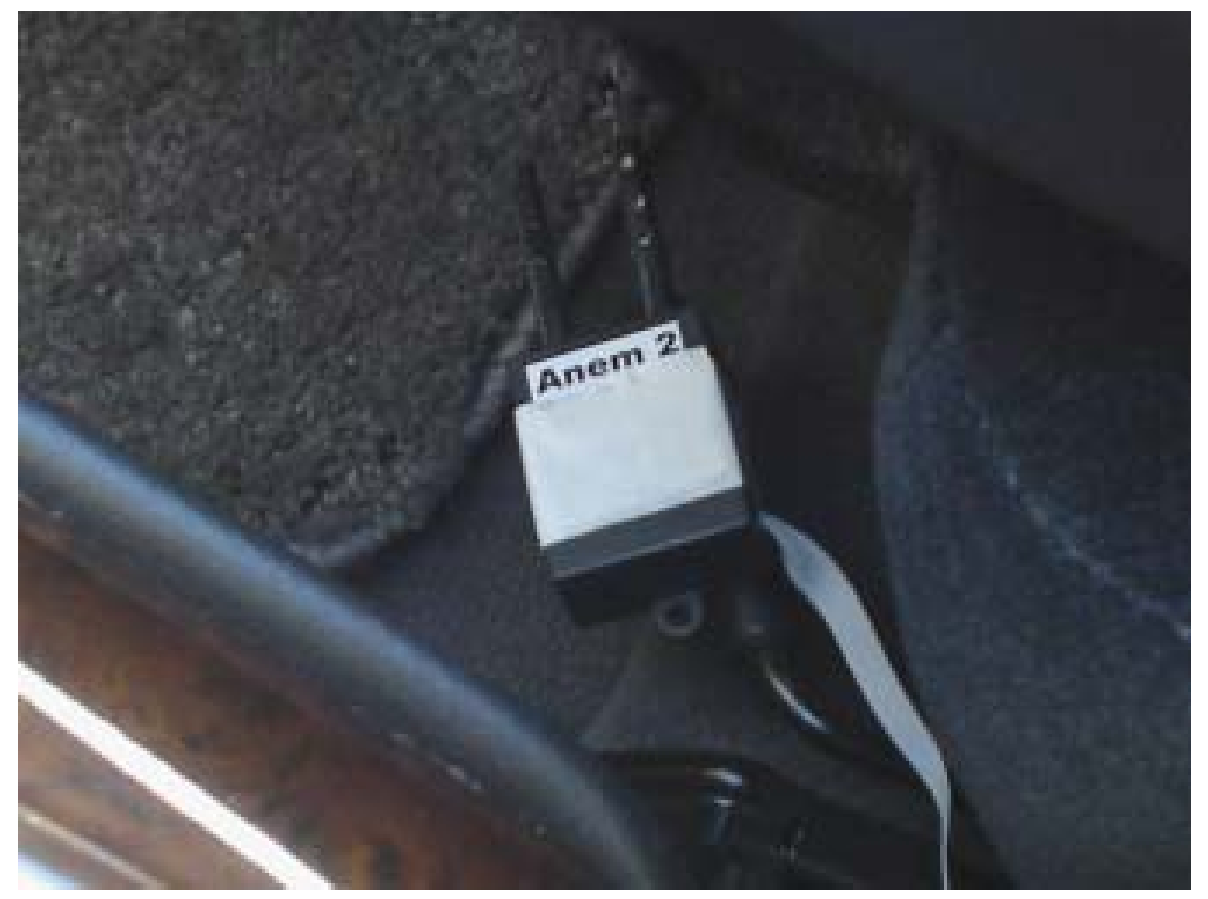

Figura 5.10 Posição do anemômetro e termômetro na altura dos pés

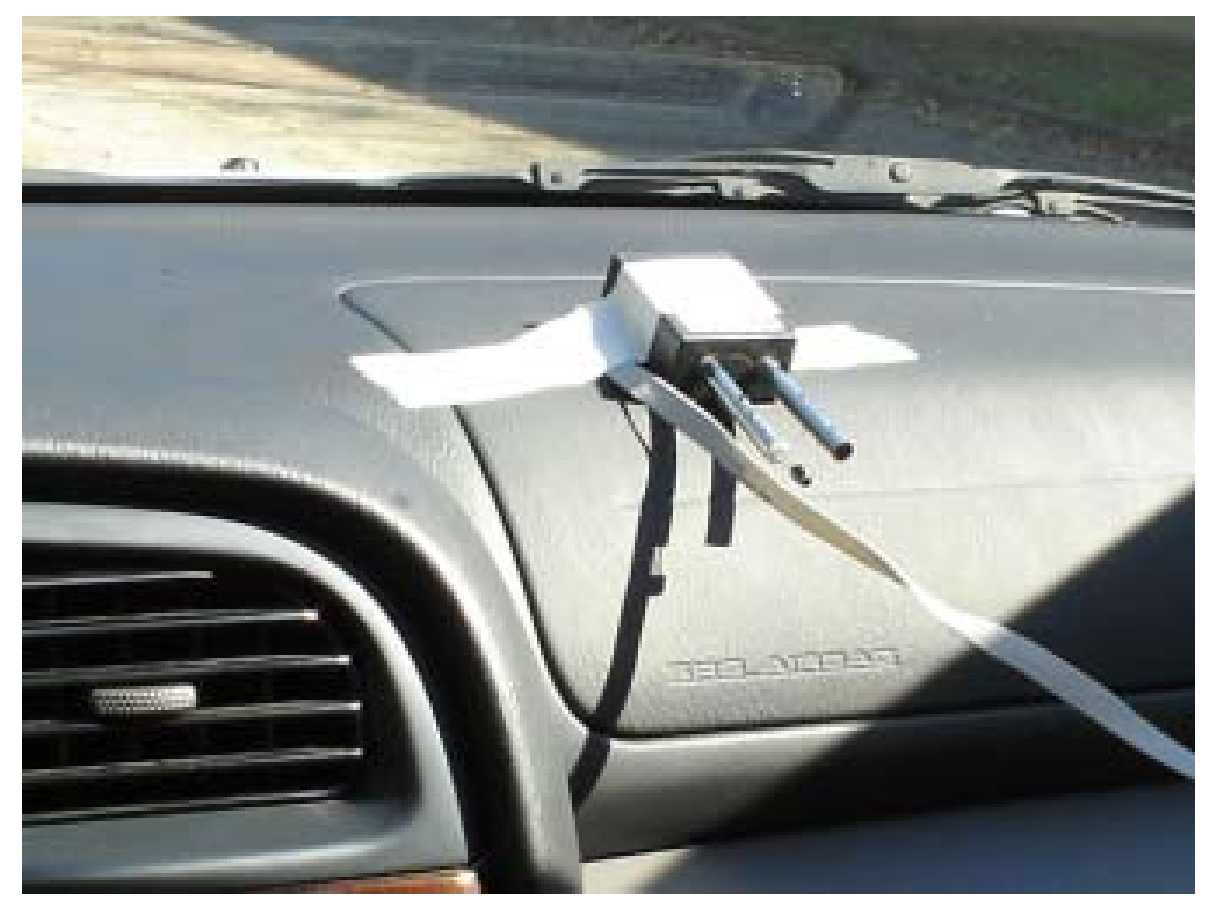

Figura 5.11 Posição do anemômetro e termômetro na altura do painel

\subsubsection{Ensaios em condições de verão}

O automóvel era estacionado ao sol. O procedimento de ensaio era iniciado por volta das 13 horas. O manequim e os demais instrumentos de medição eram posicionados 
no interior do veículo. A regulagem do sistema de controle de temperatura era colocada no frio máximo, o ventilador colocado na velocidade 2 , o fluxo de ar dirigido para as grelhas do painel, que foram colocadas nas posições centrais horizontalmente e verticalmente, e a reciclagem desligada. Uma vez regulado o sistema de controle do sistema de climatização do veículo este não era mais alterado.

As medições eram iniciadas por volta das $14 \mathrm{~h} 30 \mathrm{~m}$. Por volta das 15 horas, o carro que estava totalmente ao sol, ficava totalmente na sombra (em função da sombra projetada da edificação). Embora este fato tenha impedido realizar avaliações em regime permanente, permitiu verificar mais claramente a influência da insolação nas condições térmicas no interior dos veículos, conforme apresentado no Capítulo 6.

\subsubsection{Ensaios em condições de inverno}

O mesmo veículo instrumentado com o manequim e demais sensores permanecia estacionado na sombra com o sistema de climatização ligado "no frio" até que a temperatura no interior diminuísse. Depois o sistema de climatização era desligado e a vestimenta do manequim alterada para clo igual a 1,0 .

No início da noite, por volta das 20 horas, eram realizados os ensaios com aquecimento. A regulagem do sistema de aquecimento era colocado na posição central da escala de temperatura, o ventilador colocado na velocidade 2, o fluxo de ar dirigido para as grelhas do painel, que foram colocadas nas posições centrais horizontalmente e verticalmente, e a reciclagem desligada (de forma similar ao realizada na análise das condições de resfriamento). Uma vez regulado o sistema de controle do veículo este não era mais alterado. 


\section{CAPÍTULO 6}

RESULTADOS DOS ENSAIOS

E ANÁLISE DOS RESULTADOS

\subsection{Condições de ensaio}

A. Ensaio com automóvel de passeio denominado Veículo A

a) condições de verão

As condições climáticas eram de céu limpo e temperatura do ar de $25,5^{\circ} \mathrm{C}$. A temperatura da superfície externa do veículo sob o sol era de $56,2^{\circ} \mathrm{C}$ e a temperatura da superfície do veículo na sombra durante o ensaio caiu para $27,4^{\circ} \mathrm{C}$ (temperaturas superficiais medidas com termômetro digital de mira laser). A temperatura do ar de insuflamento foi de $8,5^{\circ} \mathrm{C}$.

b) condições de inverno

As condições climáticas eram de céu limpo e temperatura do ar de $18^{\circ} \mathrm{C}$. A temperatura da superfície externa do veículo foi de $21,6^{\circ} \mathrm{C}$. A temperatura do ar de insuflamento foi de $24,5^{\circ} \mathrm{C}$.

B. Ensaio com automóvel de passeio denominado Veículo B

a) condições de verão

As condições climáticas eram de céu limpo e temperatura do ar de $26,5^{\circ} \mathrm{C}$. A temperatura da superfície externa do veículo sob o sol era de $54,9^{\circ} \mathrm{C}$ e a temperatura da superfície do veículo na sombra durante o ensaio caiu para $27,4^{\circ} \mathrm{C}$ (temperaturas superficiais medidas com termômetro digital de mira laser). A temperatura do ar de insuflamento também foi de $8,5^{\circ} \mathrm{C}$. As condições climáticas eram de céu limpo e temperatura do ar de $26,5^{\circ} \mathrm{C}$.

b) condições de inverno

As condições climáticas eram de céu limpo e temperatura do ar de $19^{\circ} \mathrm{C}$. A temperatura da superfície externa do veículo foi de $21,5^{\circ} \mathrm{C}$. A temperatura do ar de insuflamento foi de $24,0^{\circ} \mathrm{C}$.

C. Ensaio com automóvel de passeio denominado Veículo C 
a) condições de verão

As condições climáticas eram de céu limpo e temperatura do ar de $26,5^{\circ} \mathrm{C}$. A temperatura da superfície externa do veículo sob o sol era de $52,6^{\circ} \mathrm{C}$ e a temperatura da superfície do veículo na sombra durante o ensaio caiu para $27,4^{\circ} \mathrm{C}$ (temperaturas superficiais medidas com termômetro digital de mira laser). A temperatura do ar de insuflamento foi de $11,5^{\circ} \mathrm{C}$. As condições climáticas eram de céu limpo e temperatura do ar de $26,5^{\circ} \mathrm{C}$.

b) condições de inverno

As condições climáticas eram de céu limpo e temperatura do ar de $18^{\circ} \mathrm{C}$. A temperatura da superfície externa do veículo foi de $20,9^{\circ} \mathrm{C}$. A temperatura do ar de insuflamento foi de $24,0^{\circ} \mathrm{C}$.

\subsection{Resultados dos ensaios para condições de verão}

Nas Figuras 6.1, 6.3 e 6.5 estão apresentados os gráficos de temperatura do ar no interior do veículo e nas Figuras 6.2, 6.4 e 6.6, são apresentadas as temperaturas superficiais do manequim, respectivamente, para o veículo A, veículo B e veículo C.

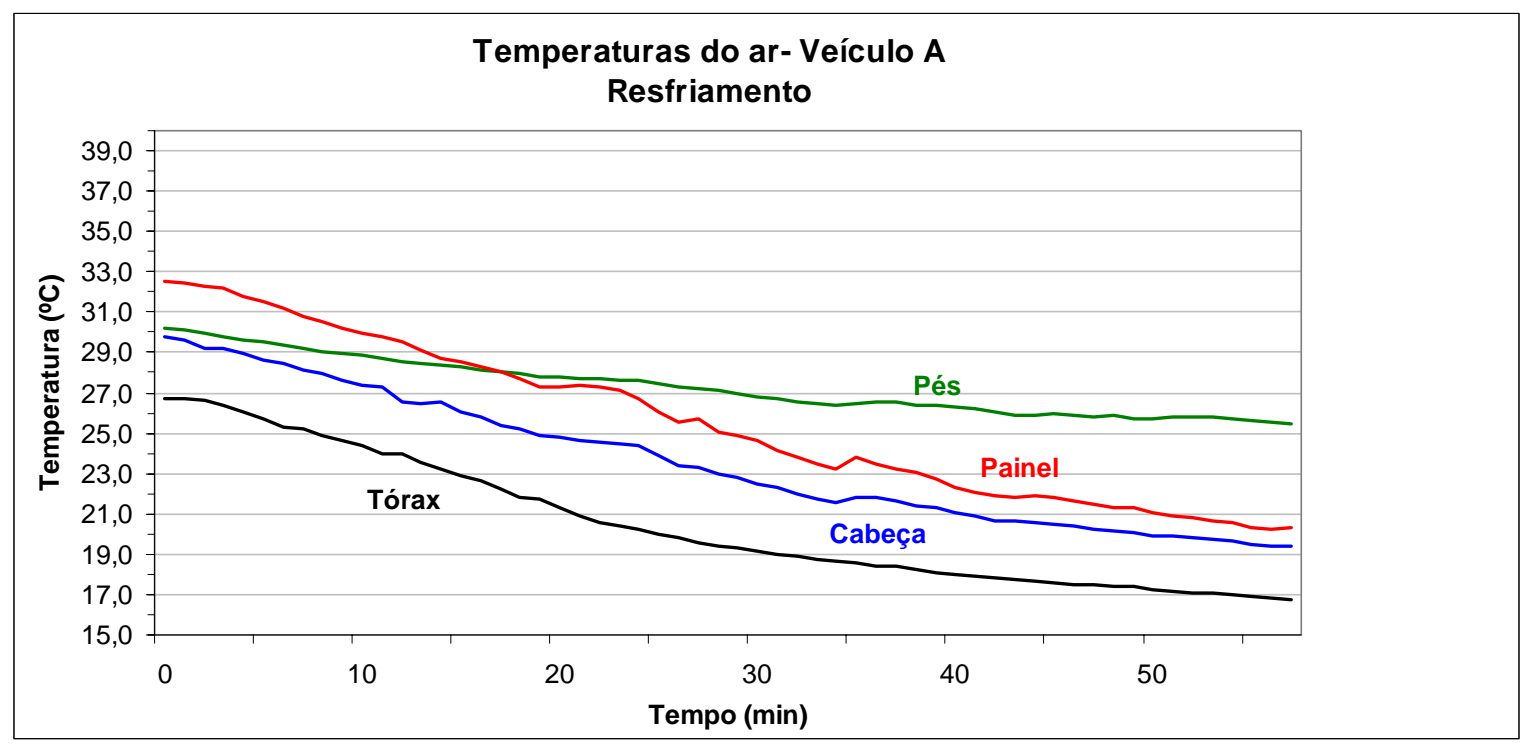

Figura 6.1 - Gráfico das temperaturas do ar no interior do veículo:

condições de verão veículo A

As legendas utilizadas na Figura 6.1 se referem às temperaturas do ar medidas, respectivamente, na altura da cabeça, do pé, do tórax e no sensor instalado no painel, conforme apresentado nas Figuras 5.8 a 5.11. Esta legenda para as temperaturas do ar no interior do veículo será utilizada em todas as análises realizadas neste capítulo. 


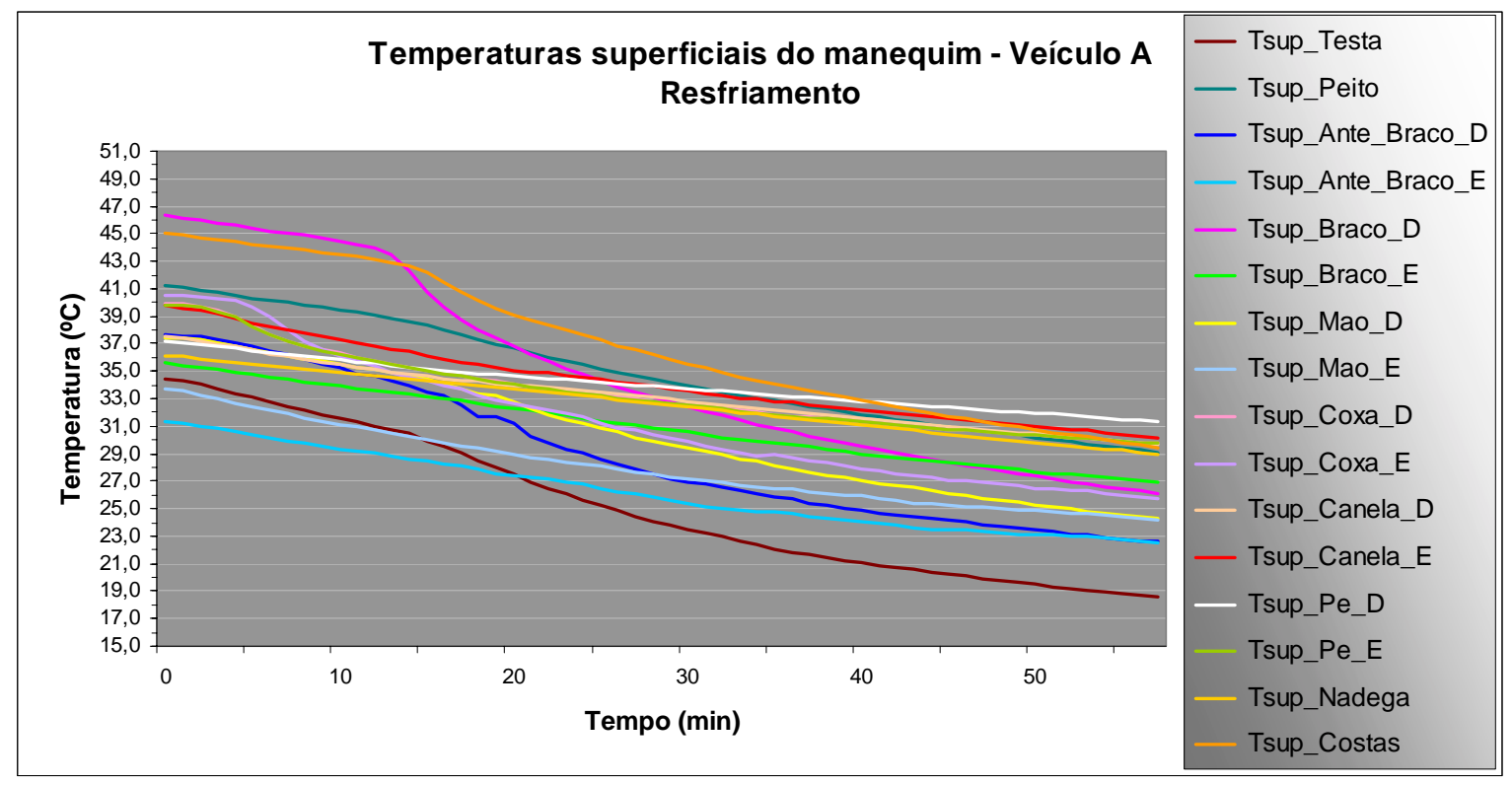

Figura 6.2 Gráfico das temperaturas superficiais do manequim:

condições de verão veículo A

Durante o ensaio houve uma alteração da posição do sol em relação ao veículo.

No início do ensaio o veículo estava totalmente ao sol e começou a ser coberto por sombra. $\mathrm{Na}$ metade do tempo de ensaio já estava totalmente coberto por sombra. Isto é evidenciado na Figuras 6.1 de temperatura no interior do veículo, onde há uma queda abrupta da temperatura na primeira metade do teste e uma queda mais branda na segunda metade do teste. Isto também é verificado com relação às temperaturas superficiais, Figura 6.2 e se repetiu em todos os testes realizados durante o dia (condições de verão).

Na Figura 6.2 também é possível verificar que as temperaturas superficiais do manequim mais próximas ao plano horizontal do fluxo de ar das grelhas do painel foram as que tiveram maior queda durante o ensaio. As temperaturas superficiais do manequim próximas ao plano do assoalho do veículo foram as que apresentaram as maiores temperaturas ao final do teste, também provavelmente devido à obstrução ao fluxo de ar causada pelo próprio manequim. As temperaturas das costas e nádegas também ficaram altas devido ao isolamento causado pelo banco.

$\mathrm{Na}$ Figura 6.3, veículo B, nota-se que a temperatura do ar na altura do plano do assoalho (altura dos pés) ficou mais próxima ao das outras temperaturas. Isto pode evidenciar uma melhor distribuição do ar neste veículo. Nota-se também um gradiente de 
temperatura menor no interior deste veículo, provavelmente devido ao sistema de controle de temperatura eletrônico usado por este veículo.

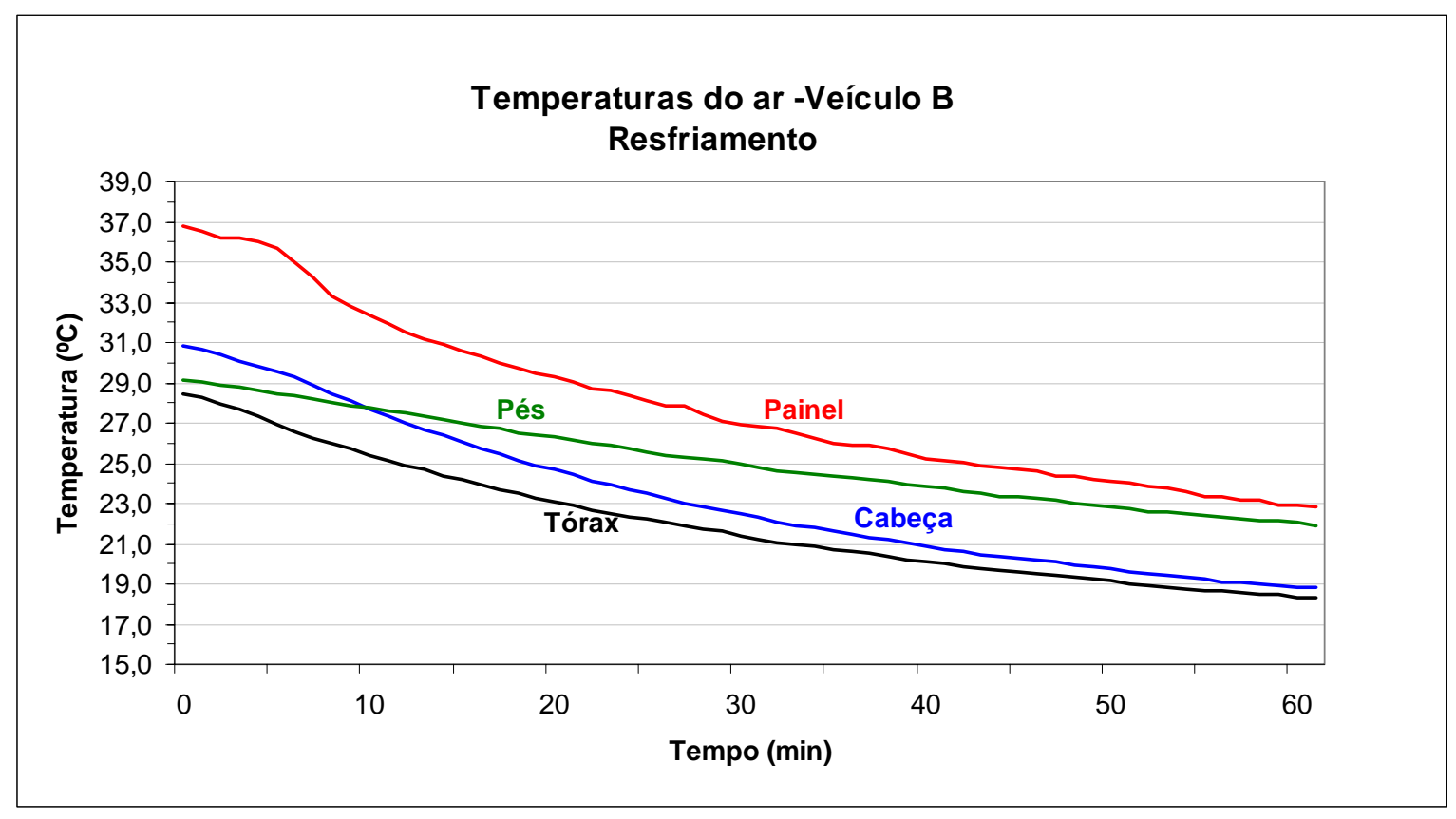

Figura 6.3 - Gráfico das temperaturas do ar no interior do veículo: condições de verão veículo B

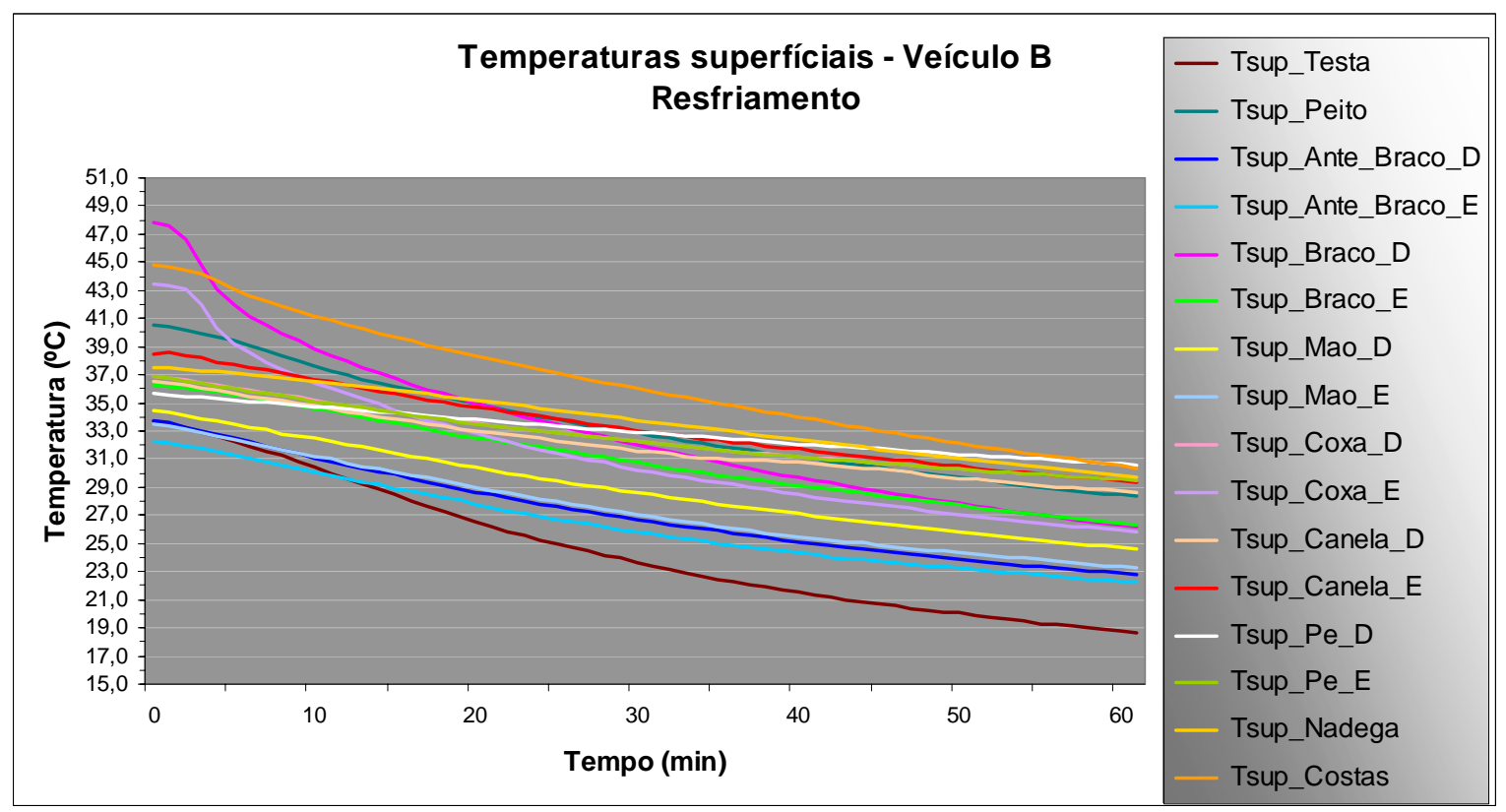

Figura 6.4 Gráfico das temperaturas superficiais do manequim: condições de verão veículo B. 
As temperaturas do ar no interior do veículo C (Figuras 6.5) foram as que ficaram mais homogêneas. Este fato realmente é interessante, pois este veículo conta com o sistema de climatização mais simples de todos. Talvez isto possa se dever ao fato da temperatura do ar insuflado não ter sido tão baixa (neste veículo foi de $11,5^{\circ} \mathrm{C}$ e nos outros dois foi de $8,5^{\circ} \mathrm{C}$ ) nos outros modelos e por isso não houve variações de temperatura maiores dentro do veículo.

Por outro lado, o veículo C apresentou as maiores variações de temperatura superficiais no manequim (Figura 6.6). Talvez isto se deva ao fato da configuração deste veículo ser do tipo caminhonete e ter uma grande área interior de troca de calor.

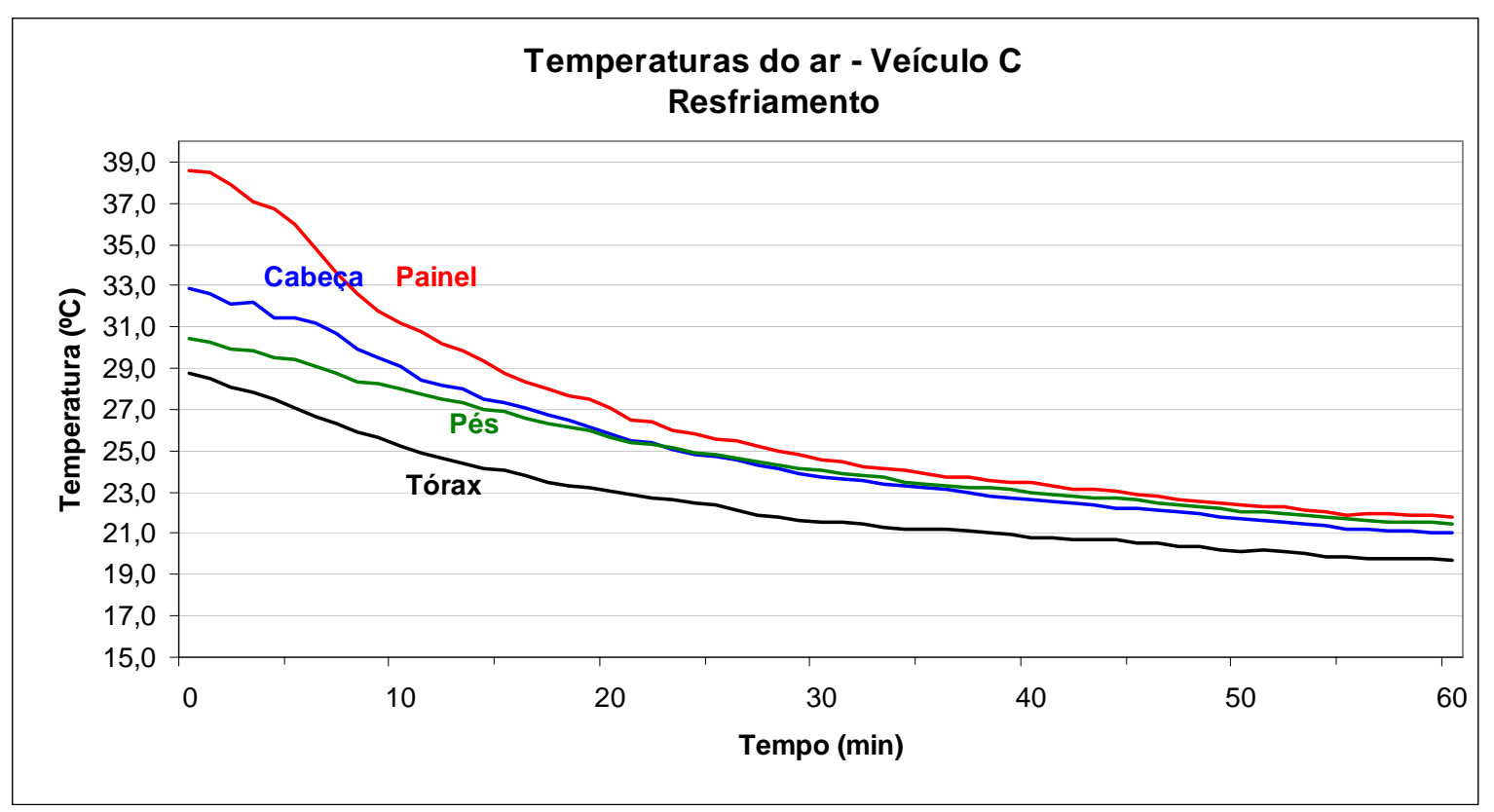

Figura 6.5 - Gráfico das temperaturas do ar no interior do veículo: condições de verão veículo C 


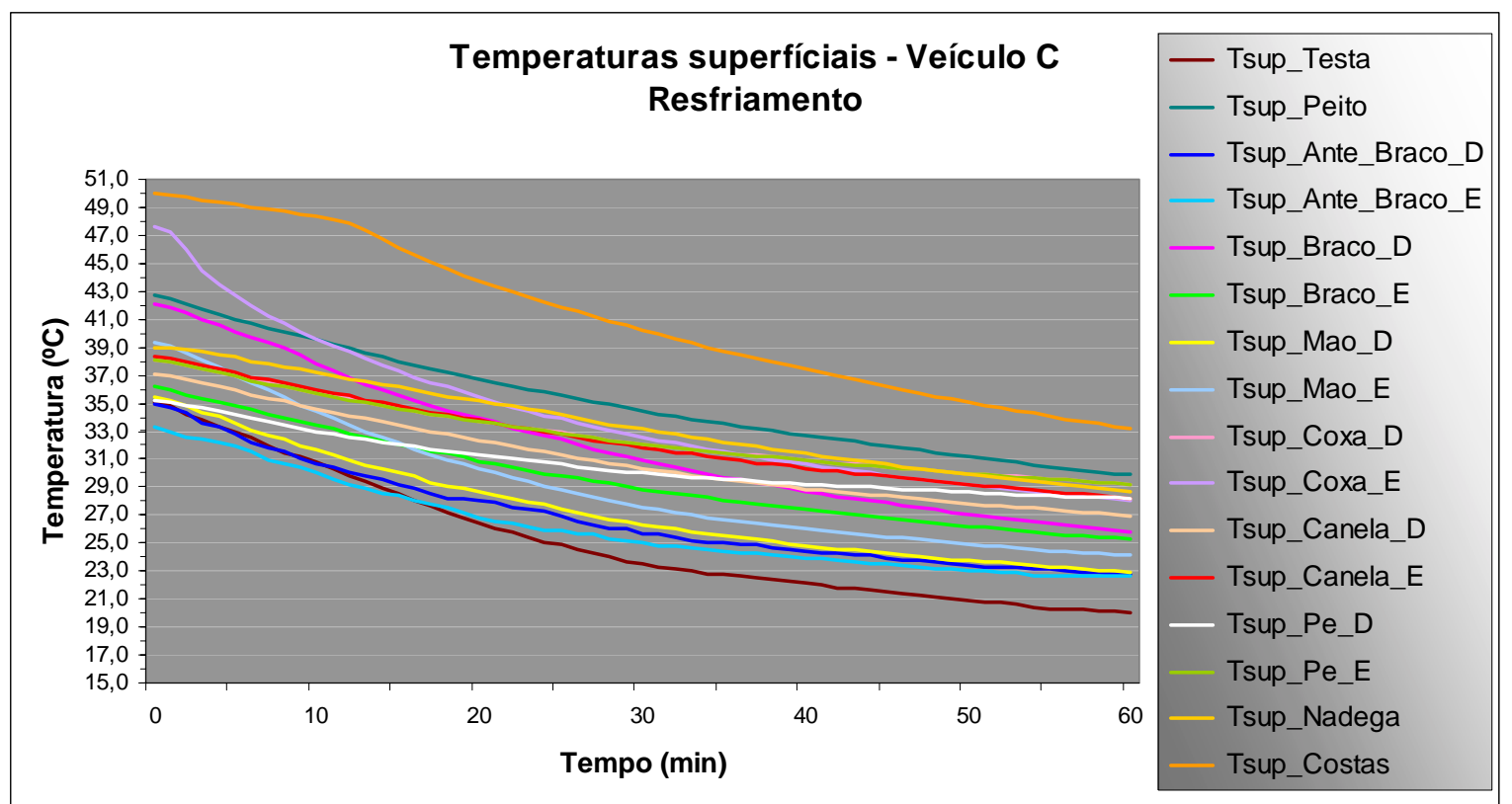

Figura 6.6 Gráfico das temperaturas superficiais do manequim:

condições de verão veículo C

\subsection{Resultados dos ensaios para condições de inverno}

Nas Figuras 6.7, 6.9 e 6.11 estão apresentados os gráficos de temperatura do ar no interior do veículo e nas Figuras 6.8, 6.10 e 6.12, são apresentadas as temperaturas superficiais do manequim, respectivamente, para o veículo A, veículo B e veículo C.

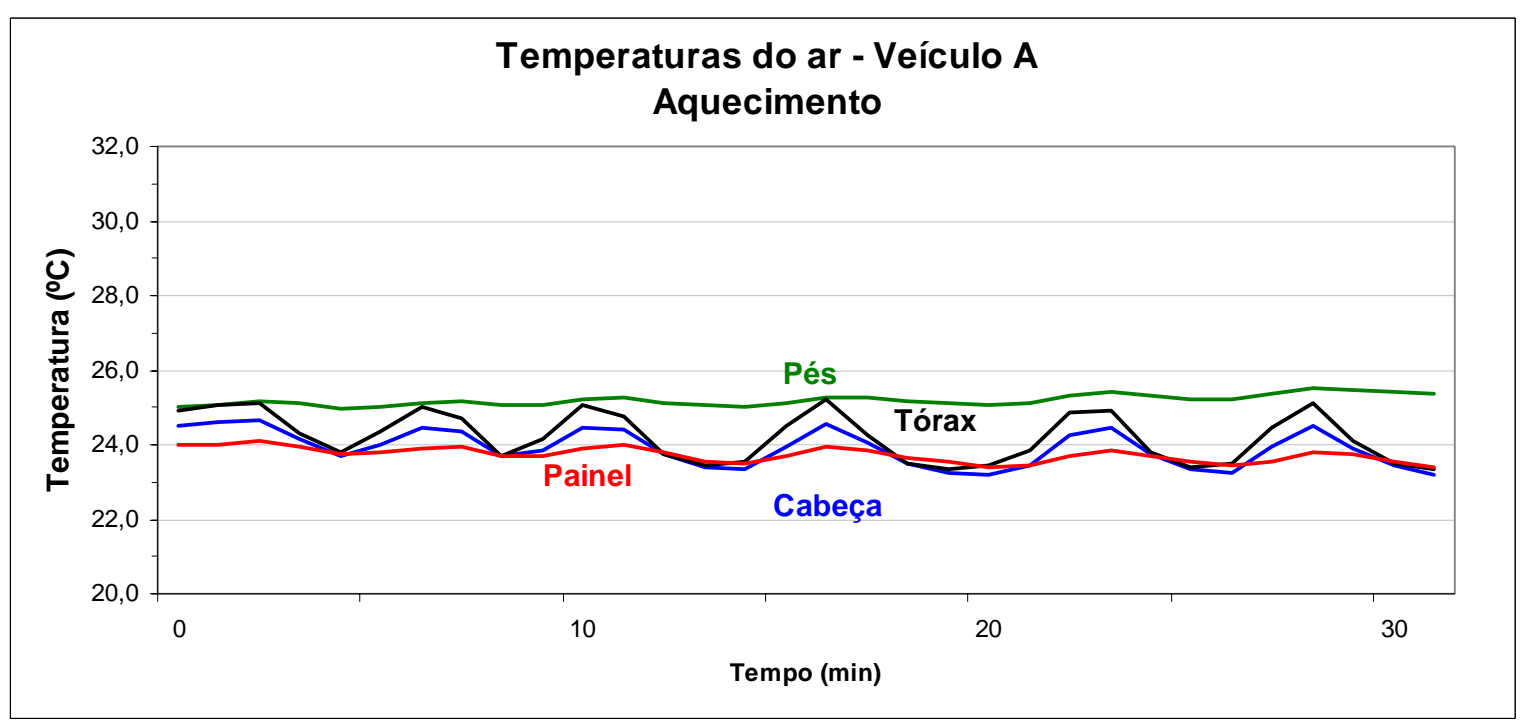

Figura 6.7 - Gráfico das temperaturas do ar no interior do veículo:

condições de inverno veículo A 


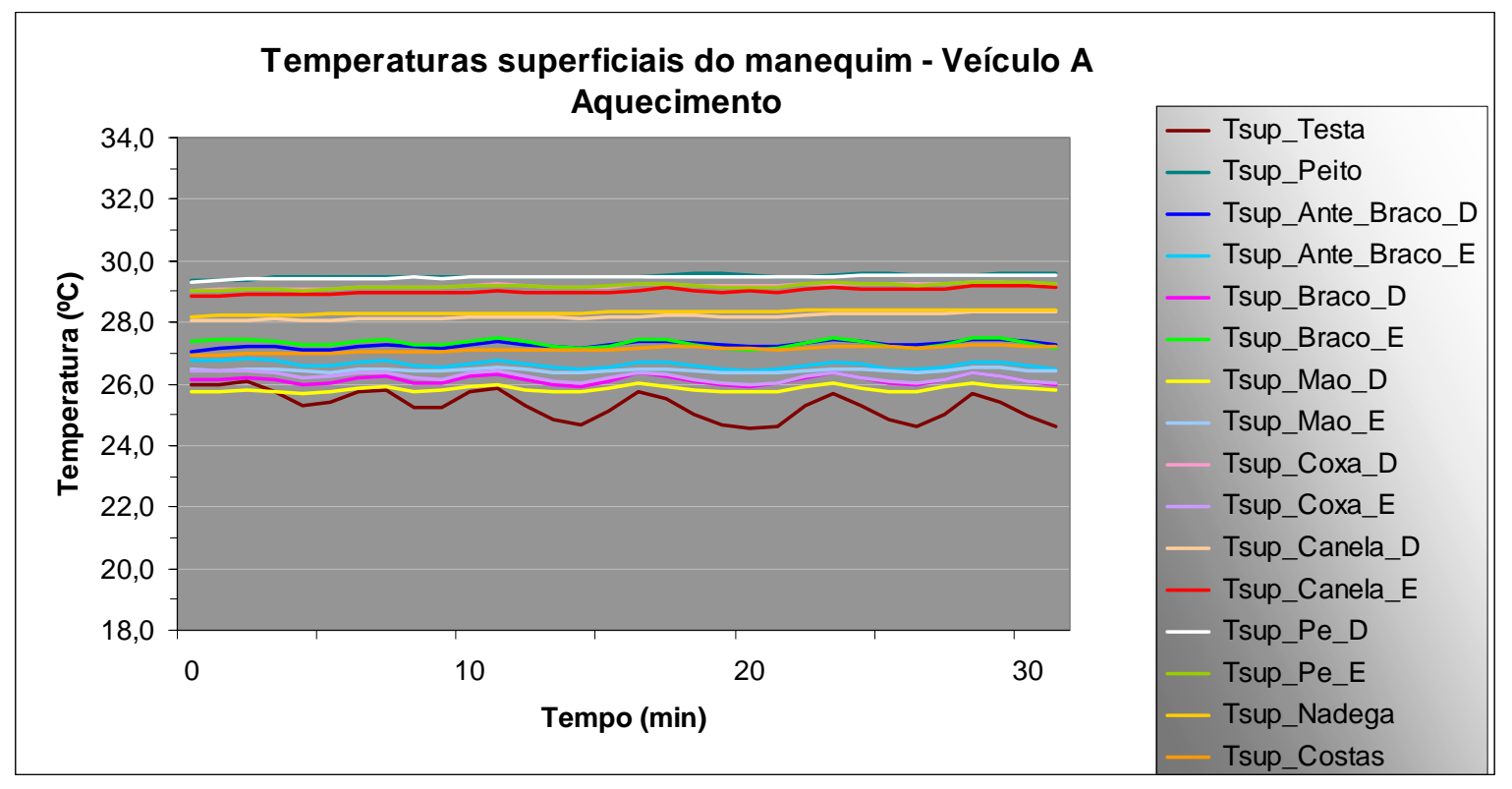

Figura 6.8 Gráfico das temperaturas superficiais do manequim:

condições de inverno veículo A

Nos resultados da Figura 6.7, veículo A, pode-se notar que a temperatura do interior do veículo na altura do assoalho (pés) foi a que se manteve mais estável. As outras temperaturas oscilaram em decorrência da ação do fluxo de ar do sistema de climatização. Esta oscilação provavelmente é decorrente do sistema de regulagem de temperatura do sistema.

Nas Figuras 6.8 e 6.9, pode-se perceber uma maior uniformidade das temperaturas do interior do veículo e superficiais do manequim, respectivamente, do que aquelas verificadas nas condições de verão. A ausência de radiação solar é a grande causa deste comportamento mais homogêneo à noite. Novamente se percebe que as temperaturas superficiais do manequim na altura do fluxo de ar do sistema de climatização oscilaram um pouco neste veículo devido ao sistema de regulagem de temperatura do sistema. 


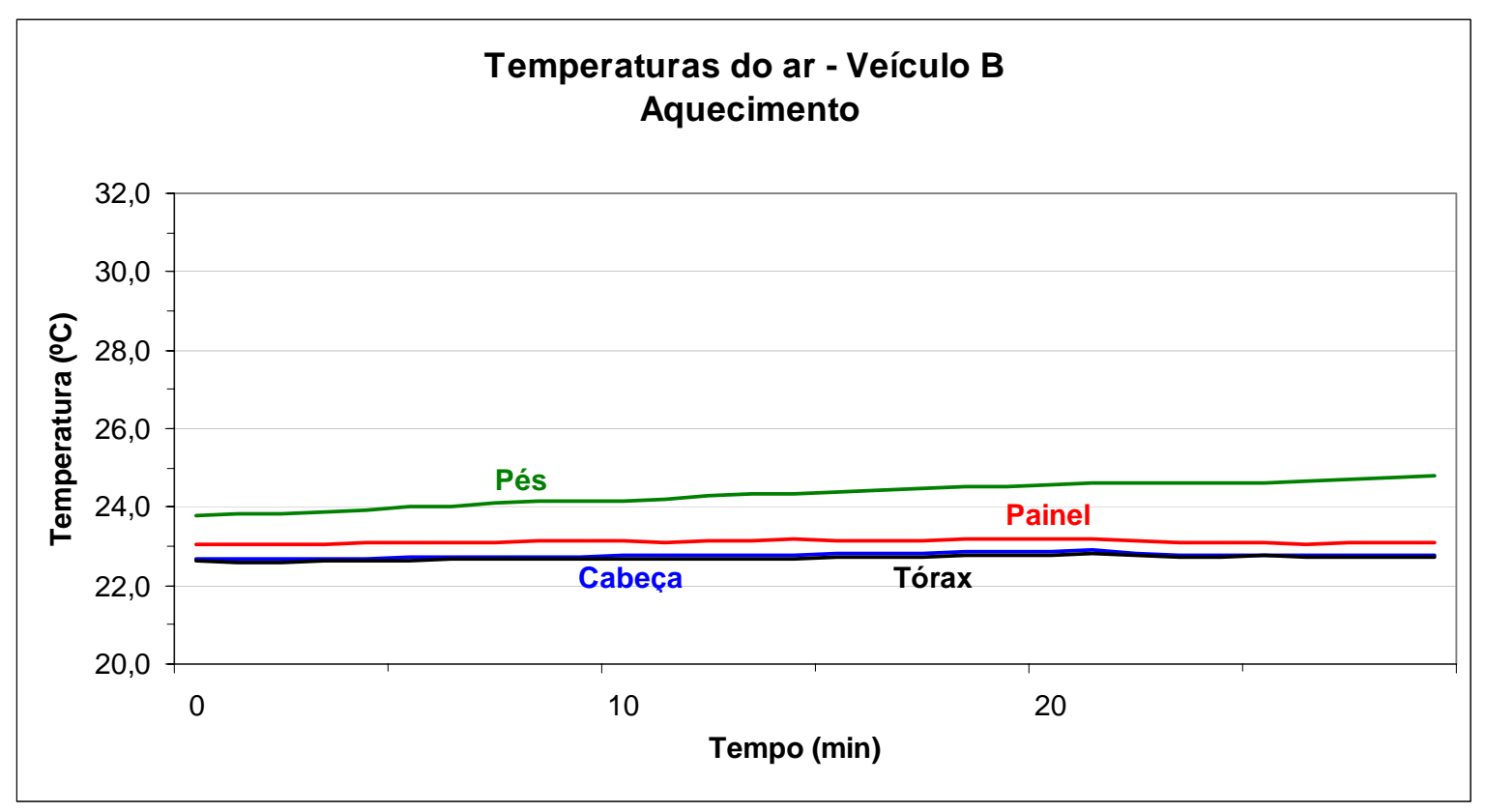

Figura 6.9 - Gráfico das temperaturas do ar no interior do veículo: condições de inverno veículo B

Na Figura 6.9, veículo B, verifica-se que a temperatura no interior do veículo na altura do assoalho teve um aumento de cerco de $1{ }^{\circ} \mathrm{C}$ durante o teste. Isto pode ser decorrente da proximidade desta área da caixa do radiador de aquecimento do ar do habitáculo.

Embora tenham sido verificadas algumas oscilações nas temperaturas do ar no interior do veículo (Fig. 6.9), os resultados das temperaturas superficiais (Fig. 6.10), mostram que neste caso foram atingidas condições de regime permanente. Isto deve ter sido possível em função da ausência de radiação solar e também porque este veículo possui um sistema eletrônico de controle de temperatura interna e uma boa distribuição de ar. 


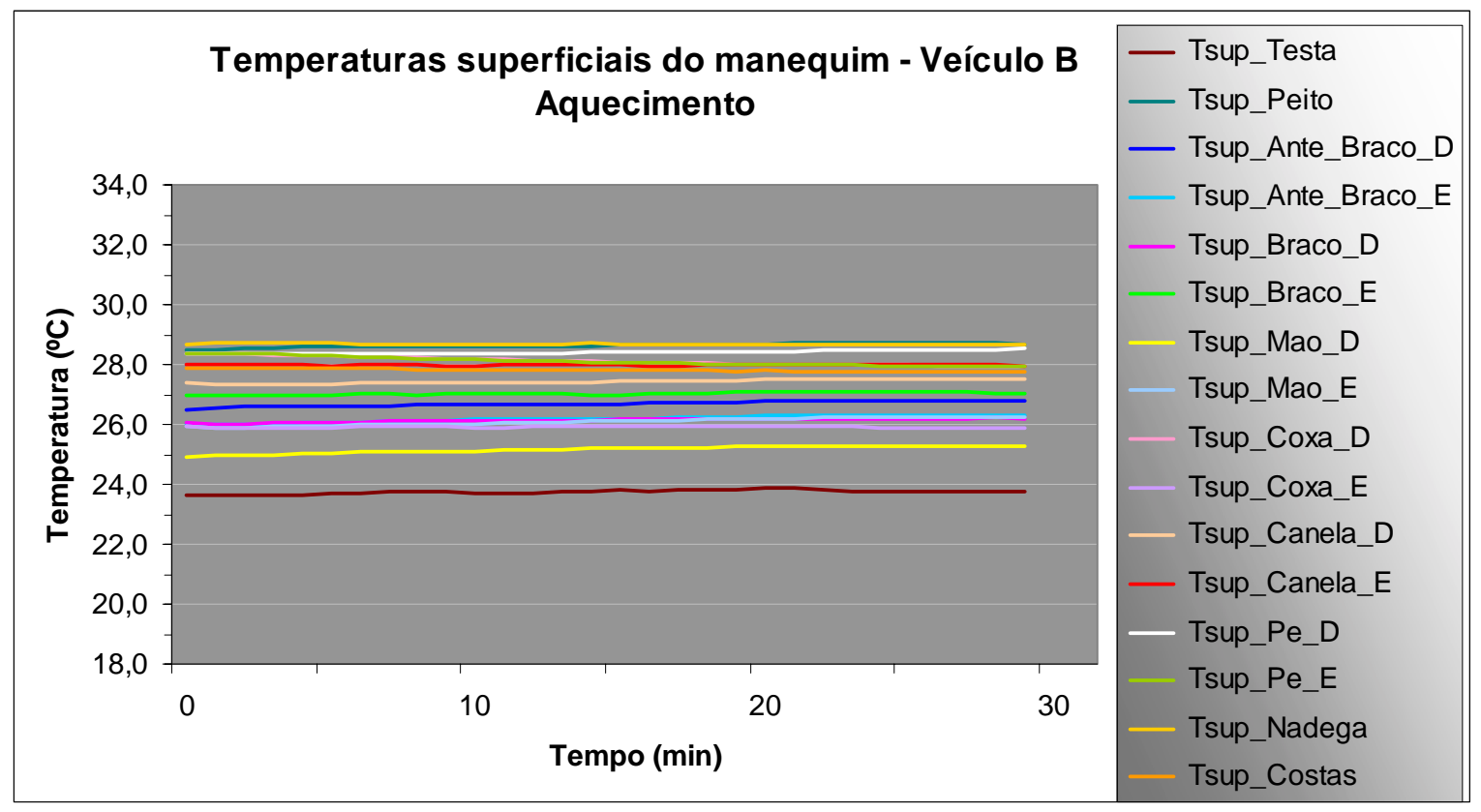

Figura 6.10 Gráfico das temperaturas superficiais do manequim: condições de inverno veículo B

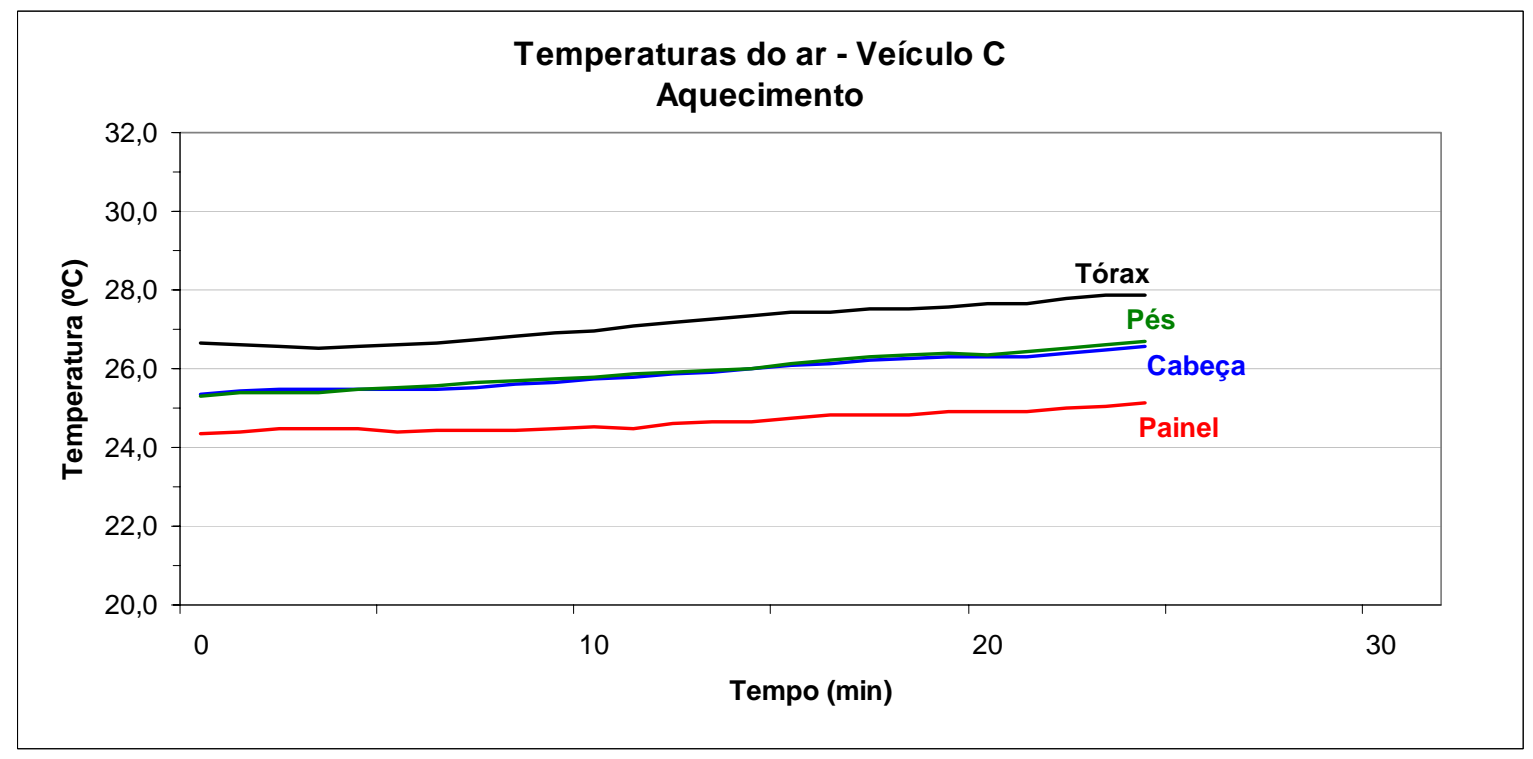

Figura 6.11 - Gráfico das temperaturas do ar no interior do veículo: condições de inverno veículo $\mathrm{C}$

No gráfico da Figura 6.11, veículo C, verifica-se que as temperaturas internas do veículo sobem durante o teste. Isto se deve à ausência de um sistema de controle eletrônico de 
temperatura. Na Figura 6.12, das temperaturas superficiais do manequim também se verifica que as temperaturas sobem um pouco ao longo do ensaio, o que provavelmente também seja devido à ausência do sistema de controle eletrônico de temperatura.

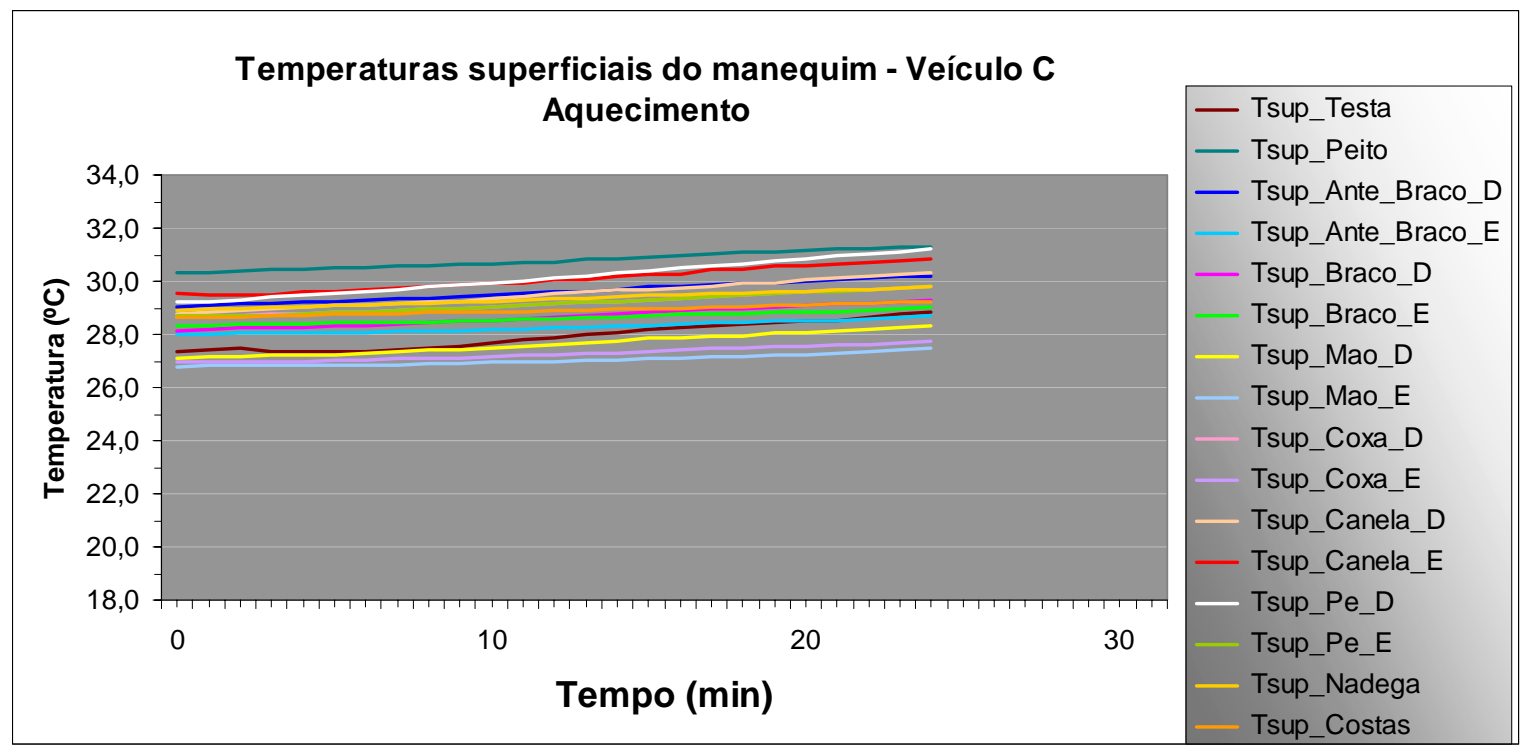

Figura 6.12 Gráfico das temperaturas superficiais do manequim: condições de inverno veículo $\mathrm{C}$

\subsection{Análise das condições de conforto térmico}

Uma vez obtidas as temperaturas superficiais, $\mathrm{t}_{s}$, (apresentadas nas Figuras 6.2, $6.4,6.6,6.8,6.10$ e 6.12) e os fluxos de calor $\mathrm{Q}$ durante os ensaios, foram determinadas as temperaturas equivalentes, $t_{\mathrm{eq}}$, para análise de condições de conforto térmico. Isto é feito utilizando-se a Eq. 4.3 modificada, isto, é com os coeficientes de transferência de calor calibrados, $h_{c a l}$, apresentados nas Tabelas 5.2 e 5.3, na equação a seguir:

$$
t_{e q}=t_{s}-\frac{Q}{h}
$$

Os valores de fluxos de calor foram mantidos o mais próximo possível de 70 $\mathrm{W} / \mathrm{m}^{2}$ com variações máximas de $2 \mathrm{~W} / \mathrm{m}^{2}$. Estas variações, contudo, não tiveram influência significativa nos resultados de $t_{\text {eq }}$, pois, conforme pode ser verificado pela análise da 
Equação 5.1, variações pequenas de Q não alteram significativamente os resultados das temperaturas equivalentes $t_{\mathrm{eq}}$.

\subsubsection{Análise das condições de conforto térmico para condições de verão (resfriamento)}

Na Figura 6.13 é apresentado o diagrama de zonas de sensação térmica da norma ISO 14505-2 (2004) com os resultados de temperatura equivalentes, $t_{\text {eq }}$, obtidos para condições de verão. A parte central do diagrama de sensação térmica (na cor branca), refere-se à região de conforto térmico.

$\mathrm{Na}$ obtenção das temperaturas equivalentes, $\mathrm{t}_{\mathrm{eq}}$, (Eq. 5.1), as temperaturas superficiais, $\mathrm{t}_{\mathrm{s}}$, apresentadas nas Tabelas 6.2, 6.4 e 6.6 (respectivamente, para o veículo A, para o veículo B e para o veículo C) foram consideradas como uma média dos valores no diagrama na condição sol (metade inicial dos gráficos) e na condição sombra (metade final dos gráficos). 


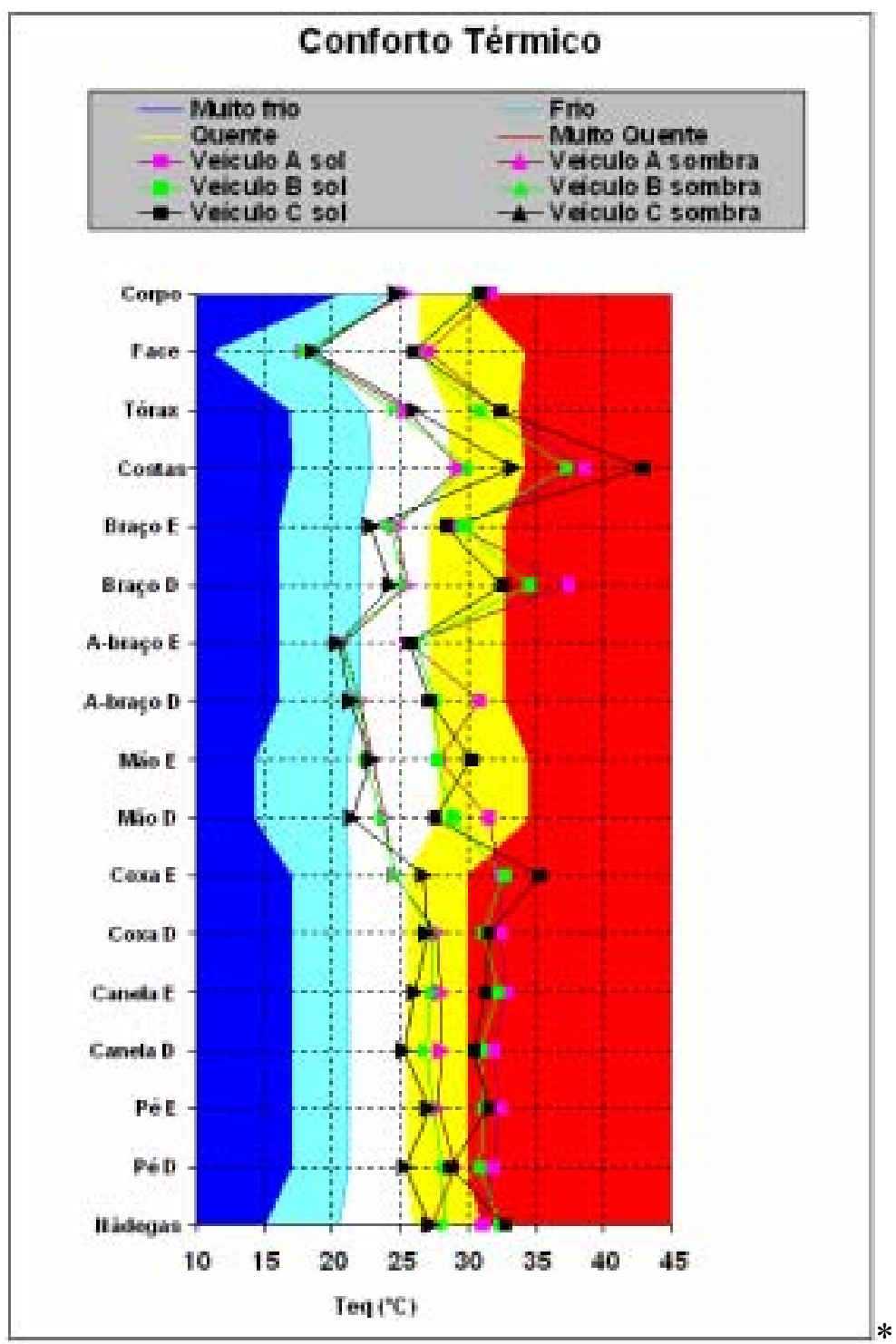

Figura 6.13 Diagrama de zonas de sensação térmica da norma ISO 14505-2 (2004) com os resultados de temperatura equivalentes obtidos para condições de verão.

Analisando-se os resultados no diagrama da Figura 6.13, pode-se verificar que em nenhum veículo foram observadas condições de conforto térmico para os vários segmentos do corpo quando os veículos estavam ao sol. Já quando o veículo estava sob a sombra, todos os veículos atingiram facilmente uma condição de conforto (inclusive com uma leve sensação de frio em alguns segmentos).

Mesmo considerando-se que os ensaios de condições de verão foram realizados em condições transientes, os resultados mostram claramente a grande influência da insolação e, por conseguinte, da radiação solar no interior do veículo; que dificulta enormemente a obtenção de condições de conforto térmico em um automóvel. 
Verifica-se também do diagrama da Figura 6.13 que o veículo B apresentou condições mais favoráveis de conforto térmico, o que deve ser decorrência de uma menor transferência de calor por radiação para dentro do veículo (qualidade dos vidros), bem como de uma melhor distribuição de ar.

\subsubsection{Análise das condições de conforto térmico para condições de inverno (aquecimento)}

Na Figura 6.14 é apresentado o diagrama de zonas de sensação térmica da norma ISO 14505-2 (2004) com os resultados de temperatura equivalentes, $t_{\text {eq }}$, obtidos para condições de inverno. A parte central do diagrama de sensação térmica (na cor branca), também se refere à região de conforto térmico.

Analisando-se os resultados no diagrama da Figura 6.14 verifica-se que, na ausência da radiação solar e com temperaturas externas mais baixas, os sistemas de climatização conseguiram proporcionar melhores condições térmicas no interior dos veículos, apresentando condições de conforto térmico em quase todas as situações.

Os resultados apresentados na Figura 6.4 foram obtidos em condições muito próximas do regime permanente para os automóveis $\mathrm{A}$ e $\mathrm{C}$ e, em condições que podem ser consideradas em regime permanente, para o automóvel B.

Também nos ensaios de condições de inverno (aquecimento), o automóvel B apresentou as melhores condições de conforto térmico; o que reforça a conclusão de uma melhor distribuição de ar naquele veículo. 


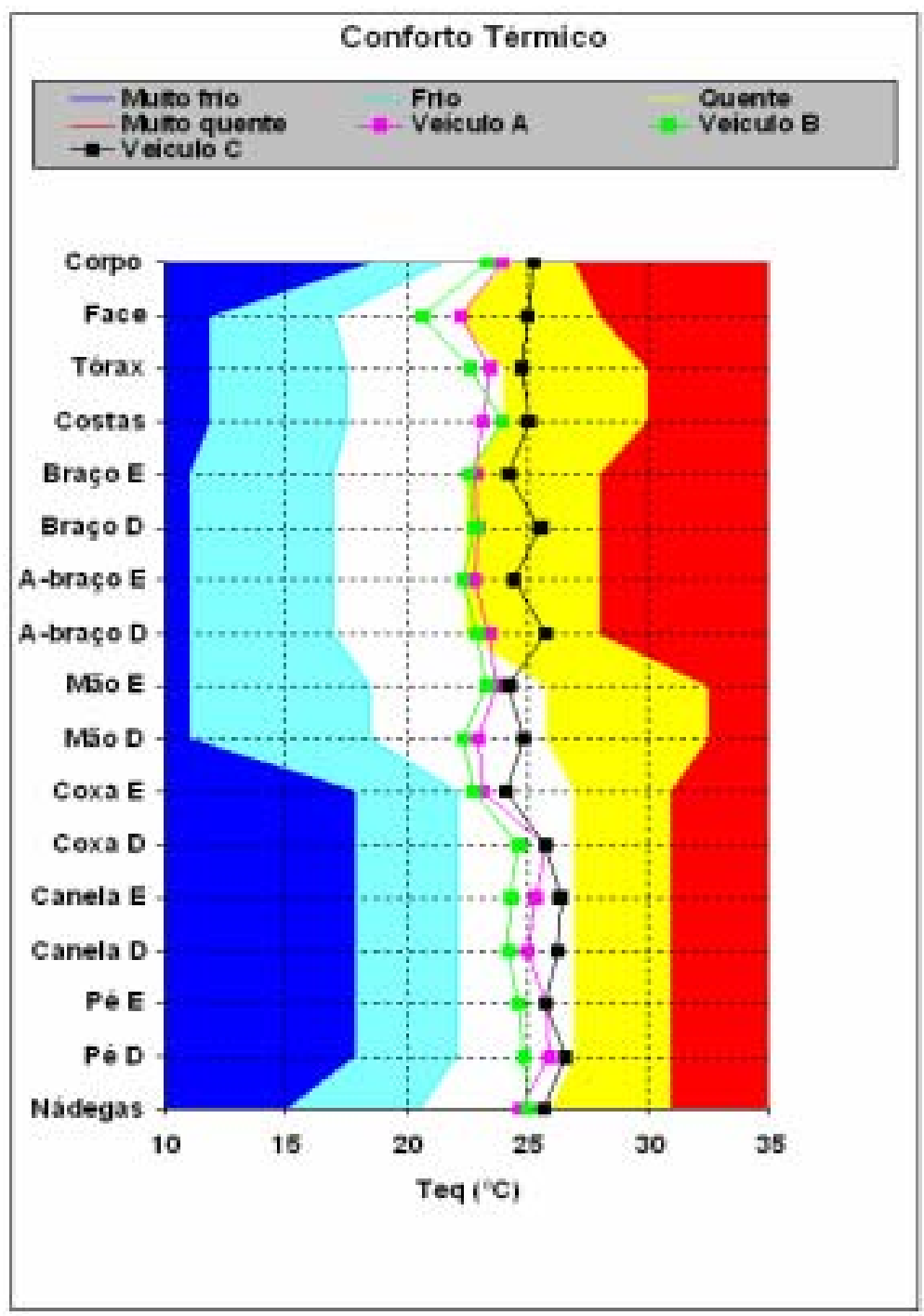

Figura 6.14 Diagrama de zonas de sensação térmica da norma ISO 14505-2 (2004) com os resultados de temperatura equivalentes obtidos para condições de inverno. 


\section{CAPÍTULO 7 \\ CONCLUSÕES}

O desenvolvimento do presente trabalho permitiu verificar a importância e a abrangência da utilização de manequins na avaliação de condições de conforto térmico em automóveis.

A utilização de manequins, em conjunto com a instalação de sensores de temperatura e velocidade, permite verificar também as condições térmicas no interior do veículo. Os resultados permitem inferir conclusões com relação à distribuição do ar, função do sistema de climatização, e de características construtivas do veículo, tais como: qualidade dos vidros (nível de transferência de calor por radiação solar) e o próprio projeto (design), na obtenção de condições de conforto térmico.

Nos ensaios realizados para as condições de verão (resfriamento), pode-se verificar que em nenhum veículo foram observadas condições de conforto térmico para os vários segmentos do corpo quando os veículos estavam ao sol. Já quando o veículo estava sob a sombra, todos os veículos atingiram facilmente uma condição de conforto (inclusive com uma leve sensação de frio em alguns segmentos do “corpo).

Mesmo considerando-se que os ensaios de condições de verão (resfriamento) foram realizados em condições transientes, os resultados mostram claramente a grande influência da insolação e, por conseguinte, da radiação solar no interior do veículo; que dificulta enormemente a obtenção de condições de conforto térmico em um automóvel.

Verificou-se também que o veículo B apresentou condições mais favoráveis de conforto térmico nas condições de verão (resfriamento), o que deve ser decorrência de uma menor transferência de calor por radiação para dentro do veículo (qualidade dos vidros), bem como de uma melhor distribuição de ar.

Nos ensaios em condições de inverno (aquecimento) verificou-se que, na ausência da radiação solar e com temperaturas externas mais baixas, os sistemas de climatização conseguiram proporcionar melhores condições térmicas no interior dos veículos, apresentando condições de conforto térmico em quase todas as situações.

Verificou-se ainda que nos ensaios em condições de inverno (aquecimento) as condições estavam muito próximas do regime permanente para os automóveis $\mathrm{A}$ e $\mathrm{C}$ e, em condições que podem ser consideradas em regime permanente, para o automóvel B. 
O automóvel B também apresentou as melhores condições de conforto térmico nos ensaios de condições de inverno (aquecimento); o que reforça a conclusão de uma melhor distribuição de ar naquele veículo.

Verifica-se, enfim, pelos resultados obtidos que um sem número de informações podem ser obtidas e extraídas de ensaios utilizando manequins e sensores adequados no levantamento das condições térmicas no interior de veículos.

Como sugestão de continuidade do trabalho, seria importante repetir os ensaios, principalmente para condições de verão (resfriamento), para analisar melhor as condições durante o resfriamento (cold down) e obter resultados mais próximas de uma condição de regime permanente. 


\section{CAPÍTULO 8 REFERÊNCIAS BIBLIOGRÁFICAS}

Ambs, R. (2002). Improved Passenger Thermal Comfort Prediction in the Preprototype Phase by Transient Interior CFD Analysis Including Mannequins. SAE Technical Paper Series 2002-01-0514, Detroit.

ASHRAE, (2001). Handbook of Fundamentals, American Society of Heating, Refrigerating and Air Conditioning Engineers. New York.

ASHRAE 55 (2004). Thermal Environmental Conditions for Human Occupancy, (ANSI/ASHRAE 55), American Society of Heating, Refrigerating and Air Conditioning Engineers, New York.

ÁVILA, J. A. (2002). Ar condicionado automotivo: Caracterização e avanços tecnológicos. Trabalho de conclusão de curso. Mestrado Profissionalizante em Engenharia Automotiva - Escola Politécnica da Universidade de São Paulo.

Brown, J.S.; Jones, B. W. (1997). A New Transient Passenger Thermal Comfort Model. SAE Technical Paper Series 970528, Detroit.

Duffon, A. F. (1932). The Equivalent Temperature of a room and its Measurement. Building Research Technical Paper 13. London.

Fanger, P.O. (1972). Analysis and Applications in Environmental Engineering. McGraw-Hill, New York.

Fanger, P.O.; Melikov, A. K.; Hanzawa, H.; Ring, J. (1988). Air Turbulence and Sensation of Draught. Energy and Buildings, N.12, pp $21-39$.

Ferreira, M. S. (1997). Um Modelo do sistema Termorregulador do Corpo Humano: Exposição a Ambientes Quentes. Dissertação de Mestrado Escola Politécnica da Universidade de São Paulo. São Paulo. 130 p.

Ferreira, M. S. (2001). Um Modelo do Sistema Térmico do Corpo Humano. Tese de Doutorado Escola Politécnica da Universidade de São Paulo. São Paulo. 166 p.

Furuse, K.; Komoriya, T. (1997). Study of Passenger's Comfort in Non-uniform thermal Environments of Vehicle Compartment. Technical Notes/JSAE Review 18 (1997) 401421, Japan. 
Gameiro da Silva, M. C. (2002). Measurements of Comfort in Vehicles. Meas. Sci. Technol. 13 (2002) R41 - R60 PII: S095-0233(02)27461-5.

Han, T.; Huang, L. (2004). A Model for Relating a Thermal Comfort Scale to EHT Comfort Index. SAE Technical Paper Series 2004-01-0919, Detroit.

Hosni, M. H., Guan, Y., Jones, B. W.; Gielda, T. P. (2003a). Investigation of Human Thermal Comfort Under Highly Transient Conditions for Automotive Applications Part 1: Experimental Design and Human Subject Testing Implementation. ASHRAE Transactions KC-03-13-1

Hosni, M.H., Guan, Y., Jones, B. W.; Gielda, T. P. (2003b). Investigation of Human Thermal Comfort Under Highly Transient Conditions for Automotive Applications Part 2: Thermal Sensation Modeling. ASHRAE Transactions KC-03-13-1

ISO 7243 (1989). Hot environments- Estimation of the heat stress on working man, based on the WBGT - index (wet bulb globe temperature), International Organization for Standardization, Genever.

ISO 7933 (1989). Hot environments - Analytical determination and interpretation of thermal stress using calculation on required sweat rate, International Organization for Standardization, Genever.

ISO 7730 (1994). Moderate Thermal Environments - Determination of the PMV and PPD indices and specification of the conditions of thermal comfort, International Organization for Standardization, Genever.

ISO 7726 (1996). Thermal environments - Instruments and methods for measuring physical quantities, International Organization for Standardization, Genever.

ISO 14505-2 (2004). Ergonomics of the thermal environment - Evaluation of thermal environment in vehicle - Part2: Determination of Equivalent Temperature. International Organization for Standardization, Genever.

Leite, B. C. C. (2003). Sistema de Ar Condicionado com Insuflamento pelo Piso em Ambientes de Escritórios: Avaliação do Conforto Térmico e Condições de Operação. Tese de Doutorado - Escola Politécnica da Universidade de São Paulo, 162 p.

Madsen, T. L. (1976). Thermal Comfort Measurements . ASHRAE Transactions 821. 
Madsen, T. L.; Olesen, B. W.; Kristensen, N. K. (1984). Comparison Bettween Operative and Equivalent Temperature Under Typical Indoor Conditions. ASHRAE Transactions 90 1077-90.

Madsen, T. L.; Olesen, B.; Reid, K. (1986). New methods for evaluation of the thermal environment in automotive vehicles, ASHRAE Transactions 92 part 1B, 38-54.

Martinho, N. A. G.; Silva, M. C. G.; Ramos, J. A. E. (2004). Evaluation of Thermal Comfort in a Vehicle Cabin. Proc. Instn Mech. Engrs. J. Automobile Engineering. Vol. 218 Part D:

Nilsson, H.O. (2004). Comfort Climate Evaluation with Thermal Manikin Methods and Computer Simulation Modes. Stockholm. Tese (Doutorado) - Department of Technology and Built Environment - University of Gaule, Sweden. 202p.

Olesen, B. W. (1988). How to Measure Mean Radiant, Operative and Equivalent Temperature Correctly. Proc. 12 Symp. on Man-Thermal Environment System. Tokyo. STEEN, R. (2001). Preparing for safe winter travel. The American National Red Cross. Disponível em:

$<$ http://www.redcross.org/news/hs/holidaysafety/011217wintertravel.html.- $>$ Acesso em 20.07.2005

Wei, K. C.; Dage, G. A. (1995). An Intelligent Automotive Climate Control System. IEEE. 0-7803-2559-1/95.

Wyon, D. P.; Tennstedt, C.; Lundgren, I.; Larsson, S. (1985). A New Method for the Detailed Assesment of Human Heat Balance in Vehicles - Volvo's Thermal Manikim, Voltman. SAE Technical Paper Series 850042. 